MATUS, JEAN PIERRE. "La doctrina penal de la (fallida) recodificación chilena del Siglo XX y principios del XXI".

Polít. crim. Vol. 5, No 9 (Julio 2010), Art. 4, pp. 143-206.

[http://www.politicacriminal.cl/Vol_05/n_09/Vol5N9A4.pdf]

\title{
La doctrina penal de la (fallida) recodificación chilena del Siglo XX y principios del XXI*
}

\author{
Dr. Jean Pierre Matus \\ Profesor Titular de Derecho penal de la Universidad de Talca \\ jpmatus@cclabogados.cl
}

\section{Resumen}

El artículo establece, a través de un análisis histórico, las principales condiciones para una auténtica nueva codificación en materia penal, a saber: a) cambio más o menos pronunciado en las valoraciones sociales acerca de lo permitido y lo prohibido, en un marco de estabilidad social y política; b) compromiso político del Gobierno de turno con la reforma (oportunidad política), y de los miembros de la Comisión Redactora del Proyecto (calidad personal); c) consenso básico en los redactores y el estamento jurídico en torno al modelo legislativo y la obra de referencia del proyecto codificador, que recojan las nuevas valoraciones sociales; y d) completitud del Proyecto. Se concluye que tales condiciones, apreciables en el proceso de codificación de 1870 a 1874, no se han dado conjuntamente en los intentos de codificación del año 1929 (Proyectos Ortizvon Bohlen y Erazo-Fontecilla), 1938 (Proyecto Labatut-Silva), 1946 (Ministerio de Justicia) y 2005 (Foro Penal), lo que explica su fracaso.

\section{Palabras clave}

Codificación penal, Chile, Proyectos de Código penal, siglo XX, siglo XXI.

\begin{abstract}
The article provides, through a historical analysis, the main conditions for a genuine new codification in criminal matters, namely: a) a more or less pronounced change in social assessments on what is permitted and what is forbidden in a framework of social and political stability; b) a political commitment of the current Government (political expediency), and the members of the Drafting Committee (personal capacity) with the reform, c) a basic consensus in the legal establishment around the legislative model and the referenced work of the Draft, that incorporates new social values, and d) completeness of the Project. We conclude that such conditions were found in the 18701874 encoding process, but not completely in the codification attempts of 1929 (Ortizvon Bohlen and Erazo-Fontecilla Projects), 1938 (Labatut-Silva Draft), 1946 (Ministry of Justice) and 2005 ("Foro Penal"), which explains their failure.
\end{abstract}

\section{Key words}

Criminal Codification, Chile, Draft Criminal Code, XX and XXI Century.

\footnotetext{
${ }^{*}$ Este artículo es resultado del Proyecto FONDECYT Nº109001, dirigido por su autor.
} 
MATUS, JEAN PIERRE. "La doctrina penal de la (fallida) recodificación chilena del Siglo XX y principios del XXI".

\section{Introducción}

Durante la primera mitad del Siglo XX, y por iniciativa gubernamental, se elaboraron en Chile cuatro Proyectos más o menos completos de recodificación penal, a saber, en 1929, los de Erazo y Fontecilla, y Ortiz y von Bohlen (sólo relativo a la parte general); en 1938, el de Labatut y Silva; y en 1946, el de la Comisión creada al efecto en 1945, que también se redujo únicamente al Libro I del Código. Posteriormente, el año 1963, y por iniciativa de su entonces Presidente, don Eduardo Novoa Monreal, el Instituto de Ciencias Penales, con el apoyo y patrocinio del Gobierno de Chile, se dio a la tarea de Coordinar la elaboración de un Código Penal Tipo para Latinoamérica, que no alcanzó a terminarse completamente, a pesar de que los trabajos de preparación se extendieron al menos hasta el año 1979. Recientemente, y ad-portas de iniciarse el nuevo milenio, por iniciativa del Ministerio de Justicia de Chile, se formó una Comisión compuesta por un importante grupo de Profesores de Derecho penal denominada "Comisión Foro Penal", la cual tras varios años de trabajo y cambios organizativos, entregó un completo Anteproyecto de Código penal a fines del año 2005 al entonces Presidente de la República, el cual nunca fue presentado al Congreso Nacional.

Como puede apreciarse, un aspecto común de todas estas iniciativas es su invariable fracaso en cuanto a su objetivo declarado, esto es, sentar las bases de una discusión parlamentaria que diese origen a un nuevo Código penal, que venga a reemplazar al ya más que centenario de 1874, a pesar del inicial apoyo gubernamental. Por lo tanto, más allá de un repaso sobre los contenidos de estos proyectos, nuestra preocupación se centrará en preguntarnos cuáles son las condiciones que hacen posible en Chile la pervivencia de nuestro decimonónico Código penal, o, al revés, que han condenado al fracaso a tales empresas, a pesar de haber intervenido en ellas lo más granado de nuestra doctrina penal de cada época.

En consecuencia, nuestro trabajo se dividirá en tres partes: en la primera, indagaremos acerca de las condiciones que teóricamente harían propicia una (re)codificación penal, reconstruyendo las que propiciaron de del siglo XIX; en la segunda, describiremos someramente los Proyectos del siglo XX, sus autores y condiciones de elaboración; y en la tercera, esbozaremos nuestras conclusiones acerca del estado actual del Proyecto de 2005 y las posibilidades de una completa recodificación en el mediano plazo.

\section{Las condiciones de la codificación penal del siglo XIX.}

\subsection{El cambio institucional: la independencia política.}

Al declararse la independencia de Chile y todavía por algunos años, siguió vigente la legislación colonial española: además de las pragmáticas, cédulas, decretos y ordenanzas reales, comunicadas a Indias a través de su Consejo, desde el 18 de mayo de 1680 hasta la proclamación de la Independencia, que figuraban en el primer lugar de prelación, se aplicaban en aquella época diversas leyes españolas en un cierto orden (fijado por el Senado Consulto de 7 de junio de 1820 y el Decreto Supremo de 28 de Abril de 1832). Prioridad tenían la Recopilación de las Leyes de Indias; la Novísima Recopilación (1805), el Fuero Real (1255), con su agregado de Leyes de Estilo, el Fuero Juzgo y las Siete Partidas (1265). ${ }^{1}$

\footnotetext{
${ }^{1}$ Con todo, a pesar del orden de prelación, especial importancia tuvo en este período las Siete Partidas. Sin embargo, como el derecho castellano concebía la ley positiva, junto a las demás fuentes del derecho
} 
De allí que una primera revisión del proceso de codificación chilena en materia penal deja entrever que éste se comenzó a intentar inmediatamente de consolidado el proceso militar de emancipación del régimen colonial español, aunque en un principio más como una suerte de buenas intenciones que de decisiones a firme, como aparece claramente en un Discurso de 1822 del entonces Director Supremo de Chile, don Bernardo O’Higgins, instando a la adopción de los “cinco códigos célebres”, impuestos por Napoleón en la Francia post revolucionaria, de manera de poder borrar "para siempre instituciones montadas bajo un plan colonial". ${ }^{2}$ A este expresado deseo codificador basado en el rechazo a la institucionalidad colonial se sucedieron varias mociones parlamentarias para constituir comisiones que redactaran los nuevos Códigos de la recién independizada nación, como las de José Alejo Eyzaguirre de 12 de noviembre de 1823; la de Muñoz Bezanilla de 28 de julio de 1826; o la de 27 de marzo de 1928, de don Francisco R. Vicuña, que derivó en un concurso al efecto, al que se presentó don Manuel Lorenzo Vidaurre y en otros escarceos legislativos, sin mayores resultados prácticos. ${ }^{3}$ Incluso existe constancia del ofrecimiento hecho por Jeremy Bentham a Bernardo O’Higgins para la redacción de un código criminal, el cual, sobra decirlo, no parece haber sido aceptado. ${ }^{4}$

\subsection{La codificación en la República Conservadora, como respuesta técnica a la pérdida de unidad y coherencia ("crisis") del derecho heredado: el Código de Bello y el fracaso de la reforma penal.}

Como resultó evidente, la sola independencia política no garantizaba las condiciones para una reforma de la farragosa legislación heredada del régimen colonial, por mucho que éste se detestase políticamente. Las turbaciones y vaivenes propios de las primeras horas de la República hicieron imposible conseguir dicho propósito.

\footnotetext{
"como una aproximación a la equidad del derecho natural" la rigurosidad de ese antiguo texto era temperada por "la búsqueda de una solución equitativa" de tipo casuístico. Esa situación perduró hasta la dictación, el año 1837, de la Ley de Fundamentación de las Sentencias. Dicho texto dispuso que el juez debía fundar el fallo, expresamente en la ley, o, en defecto de ésta, explicitar los principios de equidad. Esta nueva legislación produjo diversos problemas en su aplicación en materia penal; entre ellos, el tan conocido caso del parricidio y la obligación de castigarlo con el refinamiento de crueldad y extravagancia de la pena de las Partidas. Se sabe, así -por el testimonio del propio juez chileno enfrentado al caso- que tal disposición había quedado en desuso por no ser apropiada "al lugar, al tiempo y a las circunstancias", como exigían las Partidas para que una ley fuera considerada "justa", en el sentido del derecho natural. Así hubo de solucionarse, en materia penal, la aplicación de la exigencia de fundamentar la sentencia en la ley, estableciendo la obligatoriedad de la consulta a la Corte Suprema, en los casos en que el juez considerara que la ley penal no debía ser aplicada por la índole especialmente grave de la pena prevista en ella (Vid. FIGUEROA, María Angélica, "La codificación civil chilena y la estructuración de un sistema jurídico legalista", en FACULTAD DE DERECHO DE LA UNIVERSIDAD DE CHILE, Congreso Internacional: Andrés Bello y el Derecho, realizado con motivo del bicentenario de su nacimiento, Santiago de Chile: Ed. Jurídica de Chile, 1982, pp. 77-104, p. 78).

${ }^{2}$ GUZMÁN BRITO, Alejandro, Historia de la codificación civil en Iberoamérica, Navarra: Thomson / Aranzadi, 2006, 586 pp., p. 90.

${ }^{3}$ Ver, al respecto, RIVACOBA, Manuel de, Evolución histórica del Derecho penal chileno, Valparaíso: Edeval, 153 pp., p. 23s. Sobre el Proyecto de Vidaurre, véase el artículo especialmente dedicado a su contenido del propio RIVACOBA, Manuel de, "El Primer Proyecto Americano de Código penal", Anales del Instituto de Chile (1985), pp. 85-93.

${ }^{4}$ Aunque tampoco hay seguridad de que la carta haya sido contestada, ver: NEIRA, Marcelo, "Jeremy Bentham y el liberalismo en Chile durante la primera mitad del siglo XIX", Boletín de la Academia Chilena de la Historia, No 113 (2004), pp. 285-313, p. 294. La carta sería de mayo de 1821 o 1822 y está citada de ESTELLÉ, Patricio, "Un proyecto de código para Chile”, Historia, No 12 (1974-1975), 1976, pp. 375-381.
} 
MATUS, JEAN PIERRE. "La doctrina penal de la (fallida) recodificación chilena del Siglo XX y principios del XXI".

Para ello parecía necesario contar con la "garantía" de un "período de estabilidad socioeconómica — no necesariamente política — durante el cual el código sea elaborado y promulgado". 5

El primero de estos períodos en nuestra historia republicana es el de la denominada República Conservadora o Autoritaria, que comenzara con la presidencia provisoria de José Tomás Ovalle (1830-1831), tras la derrota de los liberales en la batalla de Lircay, extendiéndose hasta el término del segundo mandato de Montt (1861).

Con esta estabilidad, la pasión anticolonial pareció dar paso a una idea de la necesidad de la reforma de la legislación española heredada como un a respuesta a una "crisis" no ya política, sino puramente "técnica": hacer más claro y accesible el farragoso sistema normativo vigente: a partir de este momento la codificación se habría impuesto principalmente por ofrecerse "como un instrumento neutro y puramente técnico, como una nueva manera de exponer el derecho en leyes, cuya racionalidad quedaba fuera de la órbita de las discusiones ideológicas", transformándose en un "artículo de gobierno que la mayoría pudo aceptar, independientemente de sus propias concepciones sociales y políticas". ${ }^{6}$

Así, aunque en 1831 el entonces accidental Vicepresidente de la República, don Fernando Errázuriz, declarase al Congreso que:

"probablemente no se hará verosímil en la posteridad que habiendo pasado de un régimen monárquico, despótico y semifeudal a constituirnos en República representativa, con división de poderes y casi democrática, hayamos conservado por 21 años no sólo las leyes que rigen en Castilla, sino también las coloniales."7

lo cierto es que este afán de desprenderse de "las leyes de Castilla" y de las "coloniales", propias de un régimen "semifeudal" no pasaba de ser una declaración retórica, pues ya se estaba consolidando el acuerdo político de la época en orden a la mantención del sistema social heredado, pues se entendía, en la feliz expresión de Portales que "el orden social se mantiene el Chile por el peso de la noche", 8 el cual, por

\footnotetext{
${ }^{5}$ GUZMÁN BRITO, Alejandro, La fijación del derecho, Valparaíso: Ed. Universidad de Valparaíso, 1977, 128 pp., p. 12.

${ }^{6}$ GUZMÁN BRITO, Historia, cit. nota pie no 2 , p. 86.

${ }^{7}$ Cit. por GUZMÁN BRITO, Historia, cit. nota $\mathrm{n}^{\mathrm{o}} 2$, p. 102, donde pueden leerse otras proclamas del estilo por parte de las autoridades de la época.

${ }^{8}$ El texto completo es: "El orden social se mantiene en, Chile por el peso de la noche (127) y porque no tenemos hombres sutiles, hábiles y cosquillosos: la tendencia casi general de la masa al reposo es la garantía de la tranquilidad pública. Si ella faltase, nos encontraríamos a oscuras y sin poder contener a los díscolos más que con medidas dictadas por la razón, o que la experiencia ha enseñado ser útiles". Carta de Diego Portales a Joaquín Tocornal fechada en Valparaíso el 16 de julio de 1832. Reproducida en Epistolario de Don Diego Portales 1821-1837, recopilación y notas de Ernesto de la Cruz, con un prólogo y nuevas cartas recopiladas y anotadas por Guillermo Feliú Cruz (Santiago, Imprenta de la Dirección General de Prisiones, 1937), tomo II, carta 247, pp. 226-230, reproducida por GREZ TOSO, Sergio, La "cuestión social" en Chile. Ideas y debates precursores : (1804-1902), Biblioteca Nacional de Chile, disponible en Internet

en http://www.cervantesvirtual.com/servlet/SirveObras/12475174324514951887891/p0000001.htm [última visita: 15.03.2010].

En esta carta, además, sugiere Portales a Prieto, sencillamente no hacer nada más que adoptar buenas decisiones cuando se requiera, pues "estamos en el caso de huir de reformas parciales que compliquen más el laberinto de nuestra máquina, y que el pensar en una organización formal, general y radical, no es obra de nuestros tiempos", al faltarnos "hombres sutiles, hábiles y cosquillosos" que permitan el éxito de
} 
Polit. crim. Vol. 5, No 9 (Julio 2010), Art. 4, pp. 143-206.

[http://www.politicacriminal.cl/Vol_05/n_09/Vol5N9A4.pdf]

cierto, tenía su garantía normativa en la legislación española heredada, cuyas disposiciones se daban por buenas, como declaraba el Presidente Joaquín Prieto en el de Mensaje con que inauguró las sesiones del Congreso Nacional en 1836, donde señalaba:

"La reforma de la legislación civil y criminal es otra obra que caminará a la par, y en que sin apartarnos de las reglas fundamentales que, transmitidas por una larga serie de generaciones, se han connaturalizado en nosotros, reglas, además, cuya intrínseca justicia y sabiduría son indisputables, me propongo recomendaros innovaciones accidentales, que modeladas sobre las que se han planteado con buen suceso en muchas partes de Europa, servirán para poner a nuestras leyes en armonía consigo mismas y con nuestra forma de gobierno, y dándoles la simplicidad que les falta, harán más accesible su conocimiento y aplicación."

Este es precisamente el mismo sentido del Proyecto de Tocornal en la Cámara de Diputados de nombrar una comisión que fijase en términos sencillos y concisos la parte dispositiva de las Siete Partidas (1831) y otro que se atribuye a Manuel Camilo Vial en términos similares (1833). ${ }^{10}$

Y, según Guzmán Brito, este es también el contenido normativo último del Código de Bello, que tras un período de preparación de al menos un par de décadas, se aprobó en 1885 :

"resultó ser un cuerpo que sustancialmente se fundó en el antiguo derecho, reformulado al estilo de las codificaciones modernas merced a una serie de operaciones técnicas practicadas sobre aquél, y reformado de acuerdo a los cánones del liberalismo jurídico, en consonancia con el espíritu de su época, fuera de lo cual se atuvo con devoción a la vieja institucionalidad romano-castellana". ${ }^{11}$

Luego, si se dan por buenas estas conclusiones, podría decirse que lo que el Código Civil realizó fue la "reforma técnica" de la legislación vigente, sin reformarla en el

las reformas, criticando como "disparate" la adopción de la Codificación francesa por Bolivia. Según GUZMÁN BRITO, Alejandro, "Para la historia de la fijación del Derecho civil en Chile durante la República (XII). Diego Portales y la codificación”, Revista Chilena de Historia del Derecho, vol. 16 (1990), pp. 263-274, Portales estimaba que la falta de hombres con "virtudes cívicas" era una condición de hecho que hacía imposible en Chile la existencia real de una sociedad liberal en lo normativo, y por lo tanto, inútil una codificación en ese sentido (aunque teóricamente apoyase la idea y, de hecho, encomendase a Bello el inicio de los trabajos en materia civil) mientras tal condición de hecho, que se traducía en la judicatura existente en ese entonces, no fuera cambiada. En efecto, Portales, amén de la crítica al uso de las leyes españolas vigentes por su oscuridad, confusión, discordancia, vetustez y desuso, ponía en realidad todo el acento de su ineficacia en los propios jueces y no en éstas, como se infiere del siguiente pasaje extraído de su artículo sobre la "Administración de justicia Criminal” que Guzmán reproduce: “... no hay ley buena, si se descuidan los encargados de hacerla cumplir; y avanzaremos que los buenos encargados hacen buenas las leyes, pues vemos que con unas mismas se administra bien y mal la justicia" (p. 269).

${ }^{9}$ GUZMÁN BRITO, Historia, cit. nota n ${ }^{\circ} 2$, p. 110.

${ }^{10}$ DEL RIO, Raimundo, Derecho penal, t. I, Santiago de Chile: Ed. Nascimento, 1935, 320 pp., p. 310s. El Proyecto de Gabriel Tocornal está transcrito también por GUZMÁN BRITO, Historia, cit. nota $\mathrm{n}^{\circ} 2$, p. 87, y se propuso como un "contraproyecto" a otro del Senado del mismo año.

11 GUZMÁN BRITO, Historia, cit. nota $\mathrm{n}^{\circ}$ 2, p. 210. Es obvio que a esta constatación no obsta la calificación de "liberal moderado" que a Bello le atribuye JOCELYN-HOLT, Alfredo, "El liberalismo moderado del Siglo XIX”, Revista de Estudios Públicos, No 69 (1998), pp. 439-485, p. 439, pues la "moderación" del liberalismo de Bello puede radicar también en su deseo de conservar el orden civil previamente establecido, junto a los "injertos liberales" que introduce en el Código, pero que no son lo suficientemente arriesgados como para ser objeto de discusión política en la sociedad a que estaban destinados. 
MATUS, JEAN PIERRE. "La doctrina penal de la (fallida) recodificación chilena del Siglo XX y principios del XXI".

fondo, esto es, ateniéndose "con devoción a la vieja institucionalidad romanocastellana", al "peso de la noche" que gobernaba el orden de la República Conservadora. Ello explicaría su fácil despacho en el Congreso Nacional, mediante la sanción de una ley aprobatoria y absteniéndose el cuerpo legislativo de discutir el texto mismo del Código artículo por artículo. ${ }^{12}$

En cambio, amén de las propuestas de 1831, en la década de 1840, mientras el trabajo en el Código Civil iba avanzando gracias al tesón de Bello y el compromiso político del entonces Presidente Montt, una Comisión nombrada por Decreto del mismo en 1846 para el estudio de la reforma penal, no produjo ningún resultado; ${ }^{13}$ como tampoco la Ley de 14 de septiembre de 1852 que le facultaba "para asignar una renta igual a la que gozan los ministros de la Corte Suprema, a las personas a quienes comisionare para preparar proyectos de reforma de códigos". ${ }^{14}$ Sin embargo, la primera persona designada para la preparación de la reforma criminal, Antonio García Reyes, falleció al poco tiempo, sin tampoco lograr su cometido; y la persona que lo reemplazó en 1856, don Manuel Carvallo, si bien logró entregar los dos primeros Libros con 555 artículos de su Proyecto casi al finalizar el último decenio de la República Conservadora (18571859), no lo alcanzó a terminar. ${ }^{15}$ Las razones del disímil resultado de estos procesos codificadores son el objeto del siguiente apartado.

\subsubsection{Razones del fracaso de la Codificación penal en la República Conservadora}

Tres son, a mi juicio, las principales razones que explican el fracaso de la Codificación penal en la República Conservadora, a pesar de la igualdad aparente en dos de sus condiciones iniciales: reciente emancipación política y "crisis" del derecho español heredado.

a) Funcionalidad de la legislación española y las leyes patrias específicas para las condiciones sociales de la República Conservadora ("el peso de la noche”)

Durante el proceso de emancipación y hasta la consolidación de la República Conservadora, se dictaron al menos cinco leyes o decretos relativos a la libertad de imprenta, uno de los ejes cruciales de la revolución, un par destinadas a reprimir con penas de azotes y muerte ciertos robos y hurtos y otro número similar para prohibir los juegos y el envite, así como el porte de armas. En la República Conservadora se dictaron otras importantes disposiciones, pero en el mismo esquema de reformas puntuales, como la Ley de 20 de octubre de 1831, según la cual la ebriedad no era reconocida como circunstancia excluyente o atenuante de la responsabilidad criminal; la Ley de 20 de octubre de 1842, que castigaba el tráfico de esclavos (inclusive el que se

\footnotetext{
${ }^{12}$ GUZMÁN BRITO, Historia, cit. nota no 2, p. 207.

${ }^{13}$ El Decreto está transcrito en LAZO, Santiago, Código penal, orígenes, concordancias, jurisprudencia, Santiago de Chile: Ed. Poblete Cruzat Hnos., 1915, 500 pp., p. ix. En cambio, la Ley de 10 de septiembre de 1840, que creó la "Comisión de legislación del Congreso Nacional", compuesta por dos senadores y tres diputados, y que se cita frecuentemente como antecedente de la Codificación penal (DEL RÍO, Derecho penal $I$, cit. nota $n^{\circ} 10$, p. 311), en realidad tenía por objeto no la codificación criminal, sino, como se señala en su artículo 12, "la calificación de las leyes civiles, reduciéndolas a un cuerpo ordenado i completo, descartando lo superfluo o lo que pugne con las instituciones republicanas del Estado, i dirimiendo los puntos controvertidos entre los intérpretes del derecho" (El texto completo de esta Ley se encuentra en ANGUITA, René, Leyes Promulgadas en Chile, t. II, Santiago: Imp. Barcelona, 1912, 930 pp., p. 335).

${ }^{14}$ ANGUITA, Leyes II, cit. nota $\mathrm{n}^{\circ} 13$, p. 600.

${ }^{15}$ DEL RÍO, Derecho penal I, cit. nota ${ }^{\circ} 10$, pp. 311.
} 
cometía en alta mar); salvo la muy relevante Ley general sobre hurtos y robos, de 7 de agosto de 1849, materia que antaño como hoy, ocupa la mayor parte de la actividad jurisdiccional en lo criminal. ${ }^{16}$

Luego, la "tranquilidad pública", los fueros eclesiásticos y de otra índole, las relaciones familiares, la vida sexual, los fraudes y el resto de las cuestiones que regula el derecho penal quedaron así entregadas principalmente al "peso de la noche" de las valoraciones sociales españolas heredades de la época colonial pues -más allá de las necesarias adecuaciones en materias de relevancia puntual-, ${ }^{17}$ durante la República Conservadora, el anterior "orden social y económico permanec[ió] inalterado."18

b) Calidad personal y compromiso politico de los encargados de la reforma y el hecho de encontrarse incompletos de sus Proyectos

El hecho de que la Codificación decimonónica fuese un proceso generalizado de renovación del Derecho privado en Iberoamérica en el marco de la tradición romanística, dentro del cual el caso del Código civil chileno de 1855 — con independencia de sus particularidades, virtudes e influencia posterior- puede verse como uno más de los componentes de lo que Guzmán Brito denomina "subsistema de Derecho latino o iberoamericano", ${ }^{19}$ no debiera ocultar la relevancia que tuvo para su creación y actual pervivencia la persona de su redactor, don Andrés Bello, quien no sólo fue un genial jurista, poeta y gramático, sino también un importante y privilegiado funcionario de los gobiernos de nuestra República Conservadora, Rector de la Universidad de Chile desde 1842 hasta 1865, y Senador por Santiago desde 1837 a $1864 .^{20}$

${ }^{16}$ POLITOFF, Sergio; MATUS, Jean Pierre; RAMÍREZ, Ma Cecilia, Lecciones de Derecho penal chileno, parte general, $2^{a}$ ed., Santiago: Ed. Jurídica de Chile, 613 pp., p. 27s. Una exposición detallada y clasificada de estas disposiciones puede verse en DEL RÍO, Derecho penal I, cit. nota ${ }^{\circ} 10$, pp. 305 y ss. De importancia, con posterioridad a 1861, Del Río sólo menciona tres leyes, las cuales que contenían disposiciones penales en relación con el cambio social y técnico que liberalización del país iba experimentando: Ley de Ferrocarriles (1862), Ordenanza de Aduanas (1864) y la nueva Ley sobre Abusos de Imprenta (1872).

${ }^{17}$ Describe el fenómeno, dentro de un contexto de marginación del pueblo pauperizado e iletrado de entonces ("el rotaje"), para cuyo control serían suficientes y funcionales las medidas represivas de la heredada legislación española, y ciertas adecuaciones (como las leyes relativas a los azotes y la general de robos y hurtos) LEÓN, Marco Antonio, "Las ideas sobre la ley y el pueblo en la construcción y consolidación de la República chilena (1810-1860)", Historia Crítica (Bogotá), 2008, pp. 82-101, con la transcripción de este decidor párrafo aparecido en El Monitor Araucano de 19 de agosto de 1814: "Los crímenes se multiplican a proporción de la impunidad de los delincuentes. Ellos seguramente se lisonjean con el falso concepto de que el rigor de la pena haya de minorarse en los días en que se proclama la libertad. Esto es confundirla con la licencia, y tomar los abusos por principios. Una piedad mal entendida eriza el país de robos y asesinatos".

${ }^{18}$ BARROS, Enrique, "Alfredo Jocelyn-Holt: El peso de la noche. Nuestra Frágil Fortaleza Histórica”, Revista de Estudios Públicos, 70 (1998), pp. 301-307.

${ }^{19}$ GUZMÁN BRITO, Historia, cit. nota $\mathrm{n}^{\mathrm{o}} 2$, p. $137 \mathrm{~s}$.

${ }^{20}$ Para hacerse una idea de la genialidad en tales ámbitos de Bello, si no es suficiente enfrentarse a los 15 Volúmenes de su Obras Completas mandadas a imprimir por el Consejo de Instrucción Pública (Santiago de Chile: Imp. P. Ramírez, 1881-893), basta con una lectura de alguna de sus biografías, la canónica, escrita por escrita por AMUNÁTEGUI, Miguel Luis, Vida de Bello, Santiago de Chile: Imp. P. Ramírez, 1882, 672 pp., disponible en $\quad$ Internet http://www.archive.org/stream/vidadedonandrsb00amungoog\#page/n687/mode/1up [visitado por última vez el 15.03.2010]; o la moderna, de JAKSIC, Iván, Andrés Bello: la pasión por el orden, Santiago de Chile: Ed. Universitaria, 2001, 311 pp. 
MATUS, JEAN PIERRE. "La doctrina penal de la (fallida) recodificación chilena del Siglo XX y principios del XXI".

Baste para ello traer a colación el hecho de que, sea por razones de salud o de otra índole, ninguno de los comisionados o encargados directamente del trabajo de codificación penal en este período estaba no ya a la altura intelectual de Bello, cosa prácticamente imposible hasta hoy en día, sino siquiera a la de su "disciplina de trabajo" y "su sentido de la responsabilidad, ${ }^{21}$; sin contar con su compromiso político e influencia en los Presidentes y Ministros de las tres décadas de nuestra República Conservadora.

En efecto, en su calidad de Senador logró la aprobación de la Ley de 10 de septiembre de 1840, que creó la "Comisión de legislación del Congreso Nacional", compuesta por dos senadores y tres diputados, que empezó al día siguiente a trabajar en le revisión de los Títulos que Bello ya tenía avanzados e iba escribiendo. El proceso de Codificación Civil continuó con la creación, después, de una Comisión Revisora (29 de octubre de 1841) y una Comisión conjunta que las fusionaba (17 de julio de 1845), las que dejaron de funcionar alrededor de fines de ese año, lo que coincide con el cambio de formación del Congreso y las reelecciones presidenciales. En solitario, Bello siguió avanzando en sus trabajos preparatorio y, al asumir Montt la presidencia en 1851, Bello quien siguió prestándole los servicios que prestó a los anteriores Presidentes de la República Conservadora, fue designado como Secretario de la última Comisión Revisora del Proyecto ya afinado y formada al efecto por Decreto de 26 de Octubre de 1852, e integrada por el entonces Presidente de la Corte Suprema, un Ministro de la misma y otro de la Corte de Apelaciones, más tres Profesores de la Facultad de Leyes de la Universidad de Chile. ${ }^{22}$ Al mismo tiempo, se mandó a imprimir una importante cantidad de ejemplares del Proyecto, distribuyéndose copias entre ministros, jueces, parlamentarios y juristas, para recibir sus comentarios y observaciones, que Bello luego iba recibiendo e incorporando a la discusión durante el trabajo de las sesiones respectivas. Esta Comisión realizó más de 300 reuniones entre junio de 1853 y octubre de 1855, todas presididas por el propio Presidente de la República, don Manuel Montt. ${ }^{23}$ Como es sabido, los trabajos de esta Comisión desembocaron en el texto de Proyecto de Código Civil que fue presentado a discusión y aprobado por el Congreso Nacional sin reforma alguna el año 1855.

En cambio, aunque Antonio García Reyes, ${ }^{24}$ Diputado desde 1843 y por Talca en 1852 , era un prominente miembro del Partido Conservador y un gran orador (se le llamó "El Ventarrón", por la fogocidad de sus arengas), aunque de delicada salud y (quizás por ello), sin la disciplina necesaria para terminar tareas metódicas, dejando a su muerte no sólo sin avances su encargo de redactar un código penal, sino también otras dos obras inconclusas (un "Diccionario geográfico" y una "Historia nacional"), falleciendo no en Chile y enfrascado en tales tareas, sino en Lima, Perú, cuando viajaba a Estados Unidos,

\footnotetext{
${ }^{21}$ Estas cualidades, que le permitieron superar su timidez, son las que, según JAKSIC, Andrés Bello, cit. nota $\mathrm{n}^{\circ} 20, \mathrm{p} .132$, rápidamente notaría Portales, quien "se consideraba un buen juez del carácter de las personas."

${ }^{22}$ GUZMÁN BRITO, Historia, cit. nota n ${ }^{\circ}$ 2, pp. 204-207. Esta última Comisión estaba formada por los magistrados Ramón Irarrázabal, Manuel Cerdo y Alejo Valenzuela, y los jurisconsultos José Barriga y Miguel Ocampo, amén del propio Bello, su Secretario.

${ }^{23}$ JAKSIC, Andrés Bello, cit. nota no 20, p. 198.

24 Los datos resumidos aparecen en el sitio Web de Reseñas Parlamentarias de la Biblioteca del Congreso Nacional: http://biografias.bcn.cl/pags/biografias/detalle par.php?id=2492 [visitado por última vez el 15.03.2010]. A menos que se indique lo contrario, de aquí mismo se extraen los datos biográficos de Manuel Carvallo y de los miembros de la Comisión Redactora del Código penal que se transcriben más abajo.
} 
Polit. crim. Vol. 5, No 9 (Julio 2010), Art. 4, pp. 143-206.

[http://www.politicacriminal.cl/Vol_05/n_09/Vol5N9A4.pdf]

a desempeñar el cargo de ministro plenipotenciario en ese país, el 16 de octubre de 1855, lo que demuestra también la dispersión de las labores que asumía, a pesar de su delicada salud. ${ }^{25}$

Por su parte, don Manuel Carvallo también era un hombre público de importancia, ocupando diversos cargos en la Administración conservadora, particularmente en el servicio exterior, así como puestos parlamentarios desde 1826. No obstante, al momento de ser designado para la redacción del Proyecto de Código Penal, había dejado la diputación por Santiago (1852-1855) y, reiniciado sus servicios en el exterior, como plenipotenciario en Europa. ${ }^{26}$ Sin embargo, sólo alcanzó a elaborar los dos primeros Libros del Proyecto, aunque de una extensión considerable: 555 artículos. El primero, relativo a la parte general, se publicó en 1856 y el segundo, sobre los delitos cometidos por particulares, en 1859, año en que, además, se publicaron ambos conjuntamente. No obstante, el Proyecto ni fue completado ni presentado al Congreso u a otra Comisión para su revisión. Aunque algunos alegan que lo incompleto del Proyecto se debe a la muerte de su autor, ${ }^{27}$ ello no es plausible, si se toma en cuenta que ésta acaeció en 1867. Otros sostienen que el Gobierno lo abandonó, por estar insatisfecho con su texto, ${ }^{28}$ quizás debido que se basaba en el Código belga. ${ }^{29}$ Lo cierto es que, de facto, bien poco podía hacer Carvallo por el adelanto de su proyecto en Chile, encontrándose en el extranjero, en las postrimerías del segundo quinquenio de Montt y ad portas del cambio político desde la Coalición Conservadora a la Liberal. Tampoco colaboraba a ello su tardanza en la terminación de su Proyecto, que no es explicable por la simple constatación de las largas discusiones públicas del Proyecto belga sobre el cual trabajaba. ${ }^{30}$ Como sea, el nuevo Gobierno ya no se interesó en el Proyecto inconcluso de

${ }^{25}$ CABIESES, Ricardo, Derecho penal, Apuntes de clases tomados por R. Belmar, P. Gandulfo y J. Guerrero, ampliados y redactados, Santiago de Chile: Imp. Estrella del Pacífico, 1918, 221 pp., p. 97, califica la muerte de García Reyes como "prematura", y ello es cierto sólo en cuanto a su edad (38), pero no respecto al encargo remunerado que se le había hecho tres años atrás, y respecto del cual nada avanzó.

${ }^{26}$ Aunque la Reseña Biográfica del Congreso Nacional nada dice sobre la ubicación física de Carvallo en esta época, esta versión se encuentra originariamente en FERNÁNDEZ, Pedro Javier, Código penal de la República de Chile, esplicado y anotado, Santiago de Chile: Imp. El Mercurio, 1877, 143 pp., p. vi.

27 DEL RÍO, Derecho penal I, cit. nota 10, pp. 305ss, en cambio, atribuye únicamente a la muerte de Carvallo el abandono de su proyecto, hipótesis que nosotros recogimos anteriormente (POLITOFF/MATUS/RAMÍREZ, Lecciones $P G$, cit. nota ${ }^{\circ}$ 16, p. 29).

${ }^{28}$ Esta es la versión de VERA, Robustiano, Código penal de la República de Chile comentado, Santiago: Imp. Cadot, 1883, 840pp., p. 39, quien esboza la idea de que quizás "se creyera que todavía se podía exigir algo mejor". La misma versión recoge JIMÉNEZ DE ASÚA, Luis, Tratado de Derecho penal, t. I. Concepto del Derecho penal y de la Criminología, Historia y legislación penal comparada, $5^{a}$ ed., Buenos Aires: Ed. Losada, 1963 (imp. de 1992), 1435 pp., p. 1166, para quien el proyecto Carvallo se habría abandonado pues el Gobierno "no debió quedar muy satisfecho" con el mismo.

${ }^{29}$ FUENZALIDA, Alejandro, Concordancias y Comentarios del Código Penal Chileno, t. I, Lima: Imp. Comercial, 1883, 402 pp., p. x. En el mismo sentido: DEL RÍO, Raimundo, Apuntes del Derecho penal, Santiago de Chile: 1922, 356 pp., p. 81. Esta versión es verosímil, atendido el encargo diplomático que tenía Carvallo en Bélgica y la traducción del texto punitivo de dicho país que posteriormente se le encargó, y cuya publicación se hizo de manera póstuma, en 1868. Con todo, JIMÉNEZ DE ASÚA, Tratado I, cit. en la nota anterior, especula lo contrario, afirmando que quizás el Proyecto Carvallo fue abandonado porque "no se inspiraba en ese modelo", sin tomar en cuenta las fuentes más directas y las condiciones políticas reinantes.

${ }^{30}$ VERA, Código penal, cit. nota n ${ }^{\circ} 28$, p. 39, transcribe esta supuesta carta de Carvallo, del año 1863, en que, "esplicaba e estos términos la demora en la terminación de su proyecto": "La Prusia trabajó 28 años e hizo 31 proyectos ántes de adoptar el Código Penal que hoy tiene i con el cual está contenta. La Béljica ha trabajado 29 años para reformar el Código Penal que hasta ahora rije; se han publicado muchos volúmenes de proyectos, contra-proyectos, memorias e informes i solo el año anterior ha pasado en la 
MATUS, JEAN PIERRE. "La doctrina penal de la (fallida) recodificación chilena del Siglo XX y principios del XXI".

Carvallo y, aprovechando su residencia en Bruselas, le encargó la más sencilla labor de traducir el texto recién allí aprobado, traducción que se habría mandado a imprimir en $1868,{ }^{31}$ después del fallecimiento de su autor (1867), para servir de base a los trabajos de la nueva Comisión que más adelante se formó, pero sin considerar el proyecto que el propio Carvallo había antes elaborado.

\section{c) Disfuncionalidad o incongruencia entre la sociedad de la República Conservadora y una reforma penal liberal, aunque moderada}

Ya hemos visto que entre las explicaciones que se pueden ofrecen para el fracaso del Proyecto parcial Carvallo, amén de lo incompleto de su trabajo, cabe la posibilidad de que su texto no haya sido del agrado del gobierno conservador de la época si, como se dice, se basaba aquél en el Código belga, que era una revisión del napoleónico y se encontraba entonces en discusión en su país de origen. Esta incongruencia entre el Proyecto parcial de Carvallo y la sociedad de la época, como también ya se dijo, no se aprecia en el Código de Bello, que recogía la tradición hispana en formas modernas.

Esta hipótesis puede verse reforzada si se toma en cuenta que, en un también fallido intento anterior, cuando se firma el Decreto $\mathrm{N}^{\circ} 146$, de 18 de diciembre de 1846, suscrito por Manuel Bulnes como Presidente y Manuel Camilo Vial como Ministro de Justicia, donde se nombra una Comisión con el propósito de que "trabajen un proyecto de código penal y otro de procedimiento penal", aún cuando se indica que debe procederse "conforme a los principios de humanidad y de justicia que prescriben la razón y la filosofía del siglo", en sus instrucciones a los Comisionados (Srs. José Victorino Lastarria, Antonio García Reyes y Manuel Antonio Tocornal), el Ministro Manuel Camilo Vial, les señala que para formar el código punitivo, lo hagan:

"tomando por base", "el nuevo código penal de España y las reformas que en él hizo la Nueva Granada antes de adoptarlo". ${ }^{32}$

Luego, para la República Conservadora, una codificación penal no debía dejar de lado la legislación de la potencia colonial, sino hacer una que cumpliese la finalidad puramente técnica de su ordenación y simplificación en un texto único, sin apartarse de sus raíces sociales. ${ }^{33}$

Cámara de Representantes un proyecto de lei que indudablemente sufrirá modificaciones en el Senado, porque no alcanza a llenar las aspiraciones de la opinion."

31 Así figura el texto en el Catálogo de la Biblioteca del Congreso Nacional: http://www.bncatalogo.cl:80/F/VPQT2XMP59QYT3CBKXGSC4NN7H8T8GR3RR8VCMDDA25PL76 GHP-14048? \&func $=$ item-global\&doc library $=$ BNC01\&doc number $=000312257$ \&year $=$ \&volume $=\&$ sub library $=$ [visitado por última vez el 20.03.2010].

$\overline{32}$ Transcrito en LAZO, Santiago, Código penal, orígenes, concordancias, jurisprudencia, Santiago de Chile: Ed. Poblete Cruzat Hnos., 1915, 500 pp., p. IX.

${ }^{33}$ Con todo, los encargos precisos que se asignaban a esta Comisión en orden a la determinación de los delitos y la proporcionalidad de las penas, ya comienzan a dar cuenta de la penetración de un liberalismo moderado en la aproximación hacia el orden punitivo de las clases dirigentes, aunque quizás eran estos los aspectos que los Comisionados no estaban preparados para afrontar:

" $2^{\circ}$.- Al formar el proyecto del código penal, la comisión clasificará los delitos; especificará con la posible determinación todas las calidades que los agravan o atenúan; establecerá una estricta y determinada graduación de las penas; y fijará el máximum y el mínimum en que deben contenerse respecto de cada delito, para que, tomándose en consideración las circunstancias que los agravan o atenúan, se guarde en todo caso la proporción del castigo, alejando en lo posible la arbitrariedad;

“3”. La comisión prestará un especial cuidado a aquellos crímenes que son más comunes en Chile, sin pretender extirparlos por una desproporcionada severidad en las penas: dispensará más lenidad a los que 
Pero, como aún de un modo u otro las codificaciones penales europeas de principios del siglo XIX se incardinaban en la crítica política y no sólo "técnica" que del derecho del Antiguo Régimen hacía el "liberalismo", como fueran expuestas en carácter de denuncia por Beccaria, Montesquieu y otros que exigían el establecimiento de la igualdad ante la ley, la determinación de los delitos, el fin de las penas corporales y la determinación y proporcionalidad del sistema de penas, así como la reducción del arbitrio judicial; ${ }^{34}$ para su plasmación en un código en Chile, era también necesario un cambio social, siquiera mínimo, que diera entrada a esas ideas liberales, ya también a esas alturas matizadas con la caída del Imperio Napoleónico y la Restauración Europea.

\subsection{Las condiciones para la codificación penal en la República Liberal}

1.3.1. Congruencia del proyecto del "liberalismo moderado" de la segunda mitad del siglo XIX con el "eclecticismo francés" y la "escuela clásica" italiana y española

Como ya vimos, es un hecho que durante la República Conservadora se convivió con la legislación española y las nuevas leyes patrias sin mayores dificultades en la administración de la justicia penal ordinaria que el propio obrar de los jueces, según denunciaba Portales, ${ }^{35}$ al parecer la sola constatación de la "crisis" "técnica" del farragoso, confuso y vetusto Derecho penal heredado de los gobiernos coloniales, no parece haber sido una condición suficiente que condujese a su reforma radical, mediante una codificación, como tampoco fue una condicionante para ello el más relevante hecho de la emancipación política. ${ }^{36}$ Ambas condiciones parecen haber sido contrarrestadas, por así decirlo, por el "peso de la noche" y el valor intrínsecamente positivo que se le atribuía en la República Conservadora a las leyes españolas heredadas del orden colonial, no contándose tampoco con hombres como Bello para hacerse cargo siquiera de esta labor "técnica".

Luego, sólo en la medida que las ideas liberales del siglo XVIII se moderaron para hacerlas compatibles con el ethos social reinante; y, al mismo tiempo, éste no hizo suyas de algún modo, siquiera deslavado, las ideas propiamente liberales, no pareció ser el momento de que la conjunción de los restantes factores antes mencionados permitiesen la consagración de un Código penal que, en todo caso, debía afrontar la discusión política, más allá de la meramente técnica de su modelo y sistemática.

nacen de la ignorancia o sumisión, no suponen un ánimo depravado siendo la emanación de un poder extraño más o menos influyente, u obra de la inexperiencia y debilidad; y tendrá en fin presente, que la cárcel penitenciaria ofrecerá un medio eficaz de corrección para los grandes criminales, economizando la pena de muerte; pero debe también evitar, que en la graduación de las penas se empleen los medios correctivos, que deben reservarse para castigar las faltas cometidas en el establecimiento."

${ }^{34}$ Al respecto, ver POLITOFF/MATUS/RAMÍREZ, cit. nota $n^{\circ} 16$, Lecciones $P G$, pp. 23 a 27, donde se destaca el carácter confrontacional no en lo meramente técnico, sino principalmente en lo político del liberalismo francés e italiano del siglo XVIII frente al derecho del Antiguo Régimen.

${ }^{35}$ Ver nota $\mathrm{n}^{\mathrm{o}} 8$, in fine.

${ }^{36}$ Junto a estos factores, GUZMÁN BRITO, Historia, cit. nota $\mathrm{n}^{\mathrm{o}}$ 2, pp. 90-104 considera, como "factores incidentes" en la formación de la idea de codificación de Iberoamérica, la existencia de la Codificación Napoleónica, de obras de autores críticos del estado de la legislación española, el influjo de Jeremy Bentham, y el de ciertas disposiciones de la Constitución de Cádiz de 1812. Sin embargo, salvo en lo relativo al influjo de Bentham en la educación de nuestra clase dirigente, que pudo haberse sentido más allá de la época de la República Conservadora, los restantes factores estaban presentes ya en ese largo período, sin que en conjunto con los demás hubiesen permitido llegar a una codificación en materia penal. 
En cuanto al cambio social, éste llegó entre nosotros con el paso de la República Conservadora a la Liberal, al término del decenio de Montt (1851-1861). En efecto, ya a mediados de la década de 1850, y tras los sucesos de 1856, el descontento con el autoritarismo presidencial y la división de la elite favoreció la aparición de la Fusión Liberal Conservadora y los siguientes gobiernos de corte propiamente "liberal", pero "moderados" en sus aspiraciones y modos, tolerantes y abiertos al debate encauzado en el parlamento, pero "sospechoso[s] de los excesos de la democracia plebiscitaria" y "receloso[s] frente a la radicalización generada por la Revolución Francesa"; amantes del orden que permite el retiro a la actividad y el comercio privados, pero también alejados del ideal de la "restauración" monárquica; en fin un "liberalismo cauto" que se nutría "del modelo francés posterior" a la Revolución. ${ }^{37}$

Y, en lo que respecta a la matización de las ideas liberales originales en materia penal, ésta se produce a través del denominado "eclecticismo francés" de Rossi, que procuraba reintroducir las ideas de justicia moral, esto es, retomar la idea de la expiación como fin de la pena del sistema penal del Antiguo Régimen, atemperándolas con la utilidad (intimidación) en el momento de su ejecución, ${ }^{38}$ la llamada "Escuela Clásica" Italiana, representada por la monumental obra de Carrara, ${ }^{39}$ y la influencia de ambas en España, a través del liberalismo moderado de Pacheco, ${ }^{40}$ por citar a los tres primeros autores a

${ }^{37}$ JOCELYN-HOLT, Alfredo, "El liberalismo moderado del Siglo XIX”, Revista de Estudios Públicos,
No $^{\text {o }} 69$ (1998), pp. 439-485. Las citas literales son de las pp. 440s.
${ }^{8}$ GRISOLÍA, Francisco, "La reforma penal en Chile", Anuario de Derecho Penal y Ciencias Penales, Madrid (1967), pp. 289-332, p. 297s., quien demuestra en una documentada cita al pie ( $\left.{ }^{\circ} 24\right)$ la innegable influencia de las ideas de Rossi en Pacheco y Carrara.

${ }^{39}$ CARRARA, Francesco, Programa de Derecho Criminal, t. I, $1^{\circ}$, (1859), trads. J. Ortega y J. Guerrero, Bogotá: Temis, 1956, 383pp., pp. 4, 6, 26 y II, p. 68, concebía al delito únicamente como "un ente jurídico, porque su esencia debe consistir necesariamente en la violación de un derecho" (natural, dado por Dios a los hombres y deducido por la razón), y la pena como "una coacción moral que, mediante la amenaza de un mal que ha de infligirse a los violadores del derecho, sirva para apartarlos de la agresión", lo que podría entenderse como una función de utilidad de la pena. Sin embargo, rechaza las ideas del pacto social y de la utilidad como principios legitimadores del Derecho penal, reduciendo éstos a su adecuación a la norma absoluta derivadas de las "deducciones lógicas de la eterna razón, por medio de la cual reveló Dios a los hombres, por admirable inspiración, todo lo que era necesario para regular aquí abajo su conducta hacia los propios semejantes"; y en cuanto a la finalidad de la pena, afirma, en una clara reminiscencia hegeliana, que el "fin de la pena no consiste en que se haga justicia, ni en que el ofendido sea vengado, ni en que sea resarcido el daño padecido por él, ni en que se atemoricen los ciudadanos, ni en que el delincuente purgue su delito, ni en que se obtenga su enmienda. Todas estas pueden ser consecuencias necesarias de la pena, y algunas de ellas pueden ser deseables, pero la pena continuaría siendo un acto inobjetable, aun cuando faltaran todos estos resultados. El fin primario de la pena es el restablecimiento del orden externo de la sociedad."

Para un panorama detallado de cómo la ciencia penal italiana del siglo XIX y XX influyó en la nuestra, véase CARNEVALI, Raúl, "La ciencia penal italiana y su influencia en Chile", Polit. crim. N 6 (2008), A4-6, pp. 1-19, p. 3.

40 PACHECO, Joaquín Francisco, El Código penal concordado y comentado, $t$. I, Madrid: Imp. Saunaque, 1848, 551 pp., al mismo tiempo que defiende la redacción de un nuevo Código, diciendo que "de la legislación, nada era digno de respeto, nada era digno de conservación, ninguna parte se podía reservar para regla de la sociedad futura" ( p. LVI), al aclarar cómo se ha formado el nuevo Código, señala que "la comisión ha tenido presentes para su obra, por una parte las teorías de los filósofos criminalistas modernos y los preceptos consignados en todos los códigos recientes, práctica europea de la nueva civilización; y por otra parte las disposiciones de todas nuestras leyes antiguas y la jurisprudencia de todos nuestros tribunales" (p. LXIII); y afirmando la necesidad y valor de la definición legal del delito, matiza lo anterior sosteniendo que "no existiría bueno ni malo en las leyes humanas, si anteriormente a ellas no existiesen esas categorías en las Leyes de Dios, en la naturaleza del hombre" (p. 85). En cuanto a las penas, mientras rechaza la de "argolla" por "infamante" , como "la marca" y "los azotes" (p. 333), 
Polit. crim. Vol. 5, No 9 (Julio 2010), Art. 4, pp. 143-206.

[http://www.politicacriminal.cl/Vol_05/n_09/Vol5N9A4.pdf]

quienes concurría Fuenzalida para comentar nuestro Código penal de 1874 casi al momento de su promulgación. ${ }^{41}$ Todos ellos compartían más o menos las ideas de la existencia de una suerte de orden natural o filosófico más o menos racional que guiaba la legislación, del libre albedrío como base de la responsabilidad penal, de la pena como un acto de justicia o necesidad legal o natural, y de su proporcionalidad con el daño social causado; ideas que, como puede verse en el amalgamado texto de Vera sobre "Teorías del Derecho penal", ya circulaban entre nosotros en la década de $1860{ }^{42}$

De este modo se produjo alrededor de 1875 , respecto de la codificación penal, lo mismo que dos décadas atrás había acontecido con la civil, esto es,

"la congruencia de la justicia material inspiradora de la fijación con los requerimientos éticos y socioeconómicos de la sociedad cuyo tráfico jurídico aquélla aspira a regular." 43

Ello se refleja, por una parte, en el tenor de las discusiones de la Comisión Redactora, que muestran un acuerdo en los sustancial y sólo reparos en la forma de redacción de los textos que aprobaban relativos al Libro I del Código. ${ }^{44}$

Y por la otra, en el hecho de que en la tramitación parlamentaria del Código penal, a pesar de ser el primer código que se discutieron artículos particulares, se debatió con "notables discursos" no los aspectos teóricos relativos al libre albedrío como fundamento de la responsabilidad penal, ni a la proporcionalidad de las penas, etc., sino principalmente aquéllos que permitían apreciar el cambio social y político de la República Liberal frente al anterior período conservador, como los que hacían referencia a las relaciones entre los eclesiásticos y la Iglesia Católica con el Estado, que se consideraban "contrarias a la religión y a las prerrogativas de la Iglesia"; a ciertas prerrogativas familiares, vinculadas con el derecho de los maridos para dar muerte a los reos de adulterio y los casos del denominado "aborto honoris causa"; y al duelo. ${ }^{45}$

admite la de muerte, considerándola, en razón de "la enormidad de ciertos crímenes", como "en sí misma lejítima y en ciertos casos indispensable" (p. 330).

${ }^{41}$ FUENZALIDA, Código penal I, cit. nota $\mathrm{n}^{\circ} 29$, p. xii. El nombre de Pacheco se repite entre las fuentes de VERA, Código penal, cit. nota $\mathrm{n}^{\circ}$ 28, p. 52; y en FERNÁNDEZ, Pedro Javier, Código penal de la República de Chile, esplicado y concordado, $2^{a}$ edición notablemente aumentada $i$ corregida, $t$. I, Santiago de Chile: Imp. Barcelona, 1899, 452 pp., p. 62, la primera cita es de Rossi.

${ }^{42}$ VERA, Robustiano, Teorías del Derecho penal, $2^{a}$ ed., Santiago de Chile: Imp. De la República, 1882, 174 pp. La primera edición es de 1868 y la segunda -que aquí se cita- es sólo su reimpresión. Allí se afirma la existencia de una ley natural que determina la "justicia" del castigo como "la necesidad de la reparación del mal causado" (p. 47), por el mal causado y la "moralidad" y "proporcionalidad" de las penas según este principio, pero agregando que ellas deben ser "personales", "iguales", "divisibles", "análogas" a los delitos cometidos, "ejemplares", "instructivas" para el pueblo, "tranquilizadoras", "remisibles" y, finalmente, que permitan "la reforma del delincuente" (pp. 124-130), enunciado que deja ver a las claras el nivel de eclecticismo reinante en la época, más aún si se tiene en cuenta que la obra en cuestión fue "mandada a publicar en el periódico oficial" de la Universidad d Chile.

${ }^{43}$ GUZMÁN BRITO, La fijación, cit. nota ${ }^{\circ}$ 5, p. 14.

${ }^{44}$ De hecho, los Títulos I sobre los delitos y las circunstancias que eximen de la responsabilidad penal, la atenúan o agravan, el II, sobre las personas responsables de los delitos y la Escala General de penas del Título III se aprobaron sin discusión de fondo alguna (salvo quizás las coincidentes con algunas de las críticas de Pacheco, como la supresión de la pena de "argolla"), en sólo doce sesiones de la Comisión (Actas, sesiones 3 a a 14, pp. 4-26).

${ }^{45}$ Estas discusiones pueden verse en FERNÁNDEZ, Código penal, cit. nota no 41, pp. 9-49. 
MATUS, JEAN PIERRE. "La doctrina penal de la (fallida) recodificación chilena del Siglo XX y principios del XXI".

Pero tampoco se puede desconocer que esta "congruencia" se debe, también, a que el Código penal de 1874, al tomar como modelo el español de 1848/1850, participa en una medida importante de la conservación del orden tradicional, en la misma medida que, a pesar del "liberalismo moderado" de la República Liberal de la segunda mitad del siglo XIX, su tolerancia y apertura a la discusión en los aspectos valóricos, y su pragmatismo en lo económico, "en lo sustancial no había discusión”:

"El orden social era un hecho. El carácter señorial, rural, jerárquico, proclive a cooptar, que define a esta sociedad tradicional y que habría de asegurar la preeminencia oligárquica, no estaba en juego." ${ }^{46}$

En efecto, si bien el propio Pacheco señalaba en sus Comentarios que el texto del Código penal de 1848, había tomado como "modelo artístico", o "boceto", si "así puede decirse" (el cual a su vez estaba inspirado en su estructura por la Gesetz über Verbrechen und schwere Polizei - Übertretungen austríaca de 1803), lo cierto es que para "mejorarlo o completarlo en sus sus detalles", la comisión de que formó parte al redactarlo tuvo presente "por una parte las teorías de los filósofos criminalistas modernos y los preceptos consignados en todos los códigos recientes, práctica europea de la nueva civilización; y por otra parte las disposiciones de todas nuestras leyes antiguas y la jurisprudencia de todos nuestros tribunales". ${ }^{47}$ Todo lo cual lleva a Bravo Lira a sostener que "así como el CPB es derecho portugués codificado según los moldes de la ciencia penal centroeuropea, el CPE es derecho castellano, de las Partidas, la Nueva Recopilación, fueros y demás, puesto también en artículos, al modo centroeuropeo". ${ }^{8}$

Este era, por lo demás, el parecer de Alejandro Reyes, quien, en el seno de la Comisón Redactora, al proponer adoptar ese modelo español de 1848/1850, como en definitiva se hizo, argumentaba en su favor que "era una reforma verdadera de nuestra legislación vijente", 49 esto es, el derecho español colonial que había sido heradado por la joven República.

La aislada reintroducción que se hizo en Chile de la atenuante de "irreprochable conducta anterior", traída a colación en la discusión del Código precisamente con fundamento en el Código austríaco, ${ }^{50}$ cuya cita se tenía a la mano por la obra de Pacheco, ${ }^{51}$ no constituye sino la excepción que confirma la regla. ${ }^{52}$

\footnotetext{
46 JOCELYN-HOLT, "El liberalismo moderado", cit. nota $n^{\circ} 37$, p. 445. La identificación de bello con el liberalismo moderado aparece ya en la primera página del texto citado.

${ }^{47}$ PACHECO, Código I, cit. nota no 40, pp. 73 y LXIII.

48 BRAVO LIRA, Bernardino, "Bicentenario del Código Penal de Austria: su proyección desde el Danubio a Filipinas“, en Revista de Estudios Histórico-Jurídicos, N ${ }^{\circ} 26$ (2004), pp. 115-155, XI, disponible en Internet en: http://www.scielo.cl/scielo.php?script=sci_arttext\&pid=S071654552004002600005\&lng=es\&nrm=iso, [visitado por última vez el 15.03.2010].

49 Actas de las sesiones de la Comisión Redactora del Código Penal Chileno, Santiago: Imp. de la República, 1873, 314 pp.

${ }^{50}$ Actas, cit. nota anterior, sesión $8^{\mathrm{a}}$, p. 14, se lee, al final, lo siguiente: "El señor Reyes hizo presente que habían en el Código austríaco consignada otras circunstancias atenuantes que convendría asentar en el Código./Aceptada unanánimente esta indicación, fueron aprobadas con mui corto debate las siguientes, tomadas del art. 39 de ese código: " 6 . ${ }^{\text {a }}$ La de haber procurado con celo reparar el mal causado, o impedir sus ulteriores perniciosas consecuencias."/ La 8. a conservando la misma idea de la 8. del art. 39 del Código austríaco".

${ }^{51}$ PACHECO, Código penal I, p. 223.
} 
1.3.2. El consenso en el estamento jurídico en torno al modelo legislativo (el Código español de 1848/1850) y la obra de Pacheco

Según Guzmán Brito, "es también parte integrante del buen éxito de toda obra fijadora la existencia de un alto grado de perfección, tanto en la ciencia jurídica que otorga al código su sustancia como en la técnica de su formulación, por lo que toca al código mismo", requisito que es garantizado por la existencia de "un sostenido trabajo de elaboración y creación científicas por parte de los juristas sobre el derecho de sus naciones" y la existencia de "unas obras epigonales en las que culmina el trabajo anterior presentando el conjunto de sus resultados parciales y dispersos". 53

Y precisamente esas garantías se dieron al enfrentarse nuestra Comisión Redactora a la tarea encomendada, pues aún cuando sus miembros no fuesen juristas avezados en la materia penal, coincidieron en este punto fundamental: la elección de un modelo legislativo avanzado para su época, el Código penal español de 1850, teniendo a la vista su fuente, el de $1848 ;{ }^{54}$ y de una obra epigonal para su valoración crítica: El Código penal concordado y comentado, de Pacheco. ${ }^{55}$

En efecto, aunque al abrirse las sesiones de la Comisión Redactora del Código Penal, en su sesión preparatoria de 8 de marzo de 1870, el entonces Ministro de Justicia, don Joaquín Blest Gana, quien la presidió,

\begin{abstract}
"hizo presente que ha adoptado como base de la discusión el Código Penal belga porque, aunque un tanto deficiente, su precisión, claridad i sencillez lo hacian superior a cualquier otro para servir de base o punto de partida en la reforma de nuestra legislación penal. La época reciente de su publicación, por otra parte, i el largo período e veinte años que se habia gastado en su revision para la que se tuvieron en vista los cambios operados en las legislaciones penales de toda la Europa en los últimos tiempos, daban, a su juicio, una ventaja inmensa en el trabajo que se iba a emprender." 56
\end{abstract}

\footnotetext{
52 Sobre las relaciones de nuestra codificación con la centroeuropea, ver, en particular, MATUS, Jean Pierre, "Por qué citamos a los alemanes y otros apuntes metodológicos," Polít. crim. № 5 (2008), A5-5, pp. 5-7, en : http://www.politicacriminal.cl/n_05/a_5_5.pdf [visitado por última vez el 15.03.2010]. ${ }^{53}$ GUZMÁN BRITO, Fijación, cit. nota $\mathrm{n}^{\mathrm{0}} 5$, p. $13 \mathrm{~s}$.

${ }^{54}$ RIVACOBA, Evolución, cit. nota n ${ }^{\circ} 3$, p. 48, quien, siguiendo a JIMÉNEZ DE ASÚA, Tratado I, cit. nota al pie $\mathrm{n}^{\circ} 28$, p. 1166 , consiente en la idea de que el Código penal español de 1850 "era infinitamente superior al Código belga", al que el primero califica de "simple revisión del francés". En la época de promulgación del Código, FUENZALIDA, Código I, cit. nota $\mathrm{n}^{\mathrm{o}}$ 29, p. x, califica al español de 1850 "como obra científica y artística", "la primera de Europa".

55 El carácter epigonal de esta obra, al menos para el derecho español, viene dado por su carácter de "cúlmine" de una época que, con sus concordancias y constantes remisiones al derecho español precodificado y a las precedentes codificaciones europeas, "viene a resumir el conjunto de resultados parciales y dispersos ofrecidos por su predecesores", de modo que pudo "reemplazar en el uso científico y práctico al conjunto de trabajos anteriores" (GUZMÁN BRITO, Fijación, cit. nota n 5, p. 33s.), tal cual sucedió en el proceso de elaboración de nuestro Código penal. Históricamente, además, sus últimas ediciones, así como el propio Código chileno de 1874, aparecieron unos pocos años antes que las primeras obras de la Escuela Positiva que nacía en Italia y pronto encontraría seguidores en España y Latinoamérica (ver el respecto: MATUS, Jean Pierre, "El positivismo en el Derecho penal chileno: análisis sincrónico y diacrónico de una doctrina de principios del Siglo XX que se mantiene vigente, Rev. Derecho (Valdivia), vol. 20, nº 1 (2007), pp. 175-203).

${ }^{56}$ Actas, cit. nota ${ }^{\circ} 49$, sesión preparatoria, p. 3.
} 
MATUS, JEAN PIERRE. "La doctrina penal de la (fallida) recodificación chilena del Siglo XX y principios del XXI".

Dicha propuesta fue desechada por los comisionados presentes, en base a las argumentaciones de Alejandro Reyes, quien añadió a sus opiniones favorables al código español ya transcritas, añadió que su "división" era "más lógica" que la del belga, y que, además, no era "pequeña razón para esta preferencia", el que dicho código contase "con un comentador como el señor Pacheco, cuyos estudios se hallaban concordados a la vez con disposiciones de seis códigos distintos, que servirían inmensamente para ilustrar la materia". 57

La elección de este modelo y de esta obra de referencia fue recibida con "plácemes" no sólo por la doctrina posterior, ${ }^{58}$ sino por la inmediatamente siguiente a la promulgación del Código de $1874,{ }^{59}$ que, como antes hemos señalado, no dudó en utilizar los Comentarios de Pacheco como fuente para su propia interpretación de nuestro texto punitivo, llegando incluso a la copia literal. ${ }^{60}$

1.3.3. La calidad personal y el compromiso político de los Miembros de la Comisión Redactora del Código penal

Aunque ninguno de los juristas designados por decreto de 17 de enero de 1870 del entonces Ministro de Justicia, don Joaquín Blest Gana para integrar la Comisión Redactora de un Proyecto de Código Penal, ${ }^{61}$ pueda estar a la par con la genialidad de Bello, sí poseían al menos similar e incluso mayor peso político en el gobierno de la época que éste en los que sirvió: la mayor parte de ellos no sólo eran prominentes políticos de la entonces coalición Liberal gobernante, sino, además, autoridades principales de la República, incluyendo varios Ministros y ex Ministros de Estado, Senadores, Diputados y miembros de los Tribunales Superiores de Justicia de la época, quienes podían, como de hecho lo hicieron, influir en la comunidad jurídica para lograr la aprobación del Código y su adopción plena por los Tribunales de justicia. ${ }^{62}$

En efecto, su Presidente en ausencia del Ministro de Justicia, don Alejandro Reyes Cotapos había sido antes Ministro de Hacienda, y era al momento de iniciar sus trabajos la Comisión, Ministro del Interior y de Relaciones Exteriores, asumiendo luego como Senador por Curicó y Ministro de la Corte Suprema de Justicia, de la cual llegaría a ser su Presidente en 1882, amén de ejercer la Cátedra del curso del ramo en la Universidad de Chile.

\footnotetext{
${ }^{57}$ Actas, cit. nota $\mathrm{n}^{\mathrm{o}} 49$, sesiones preparatoria y $2^{\mathrm{a}}$., p.3s.

${ }^{58}$ Es la expresión que emplea JIMÉNEZ DE ASÚA, Tratado I, cit. nota nº 28, p. 1166.

${ }^{59}$ Como se aprecia de estas palabras de FUENZALIDA, Código penal I, cit. nota no 29, p. x: "Esta comisión, con un acierto que bastaria para su elogio si no tuviera otros titulos, adoptó por base el Código Español de 1850."

${ }^{60}$ Véase al respecto MATUS, Jean Pierre, "Fernández, Fuenzalida y Vera: Comentaristas, autodidactas y olvidados. Análisis diacrónico y sincrónico de la doctrina penal chilena del siglo XIX", Ius et Praxis, Vol. $12, n^{\circ} 1$ (2006), pp. 31-67.

${ }^{61}$ Ellos fueron: José Alejo Valenzuela, Alejandro Reyes Cotapos, don Eulogio Altamirano, José Antonio Gandarillas, José Clemente Fabres, José Vicente Abalos, y Manuel Rengifo, quien actuó como redactor, asignándosele un sueldo especial. Posteriormente, en febrero, se integra don Diego Armstrong, y a mediados de julio de ese año, deja de concurrir Abalos y es reemplazado por Adolfo Ibáñez. Actuaron como Secretarios, sucesivamente, Julio Prieto Urriola, Robustiano Vera y Osvaldo Rengifo (RIVACOBA, Evolución, cit. nota n ${ }^{\circ} 3$, pp. 41s.).

${ }^{62}$ Véanse, por ejemplo, las importantes intervenciones de Fabres, Altamirano y Reyes en las discusiones habidas en el Congreso nacional, transcritas por FERNÁNDEZ, Código penal, en la obra y lugar citados en la nota al pie $\mathrm{n}^{\mathbf{0}} 45$, y el discurso del propio Alejandro Reyes, de 29 de marzo de 1875, con que inauguró su Cátedra de "Profesor de Código Penal" de la Universidad de Chile, transcrito en VERA, Código penal, cit. nota $\mathrm{n}^{\mathrm{o}} 28$, pp. 53-70.
} 
Polit. crim. Vol. 5, No 9 (Julio 2010), Art. 4, pp. 143-206.

[http://www.politicacriminal.cl/Vol_05/n_09/Vol5N9A4.pdf]

También Ministro de Estado, en Hacienda, era al momento de integrarse a la Comisión Redactora don José Antonio Gandarillas, quien al comenzar en 1871 el Gobierno de Errázuriz pasó a desempeñarse como Ministro Suplente de la Corte de Apelaciones de Santiago, asumiendo en propiedad en 1875. Posteriormente, durante la Guerra del Pacífico, ocupó el cargo de Ministro de Justicia, Educación y Culto, obtenido más adelante una diputación y una senaduría por el Maule.

Por su parte, don Eulogio Altamirano, siendo Juez del Crimen en Santiago al momento de integrar la Comisión, llegó a ser Ministro de Justicia unos meses después, durante al año 1870, y Ministro del Interior durante toda la presidencia de Errázuriz (1871-1876). Y don Manuel Rengifo, quien recibía sueldo especial como redactor, había sido antes también Ministro de Hacienda de Pérez, participó en el Congreso Constituyente de 1870 y ejerció la Diputación por Santiago entre 1870 y 1876, habiendo sido antes Diputado por Curicó.

Militante del Partido Conservador, don José Clemente Fabres, era Profesor de Código Civil en la Universidad de Chile (y luego fundador de la Universidad Católica) y llegó a ser Diputado suplente por Rancagua en 1873 y Senador por Cachapoal entre 1891 y 1897.

Finalmente, de aquéllos que menos participación tuvieron en la redacción del Código, la integraba nominalmente el entonces Presidente de la Corte Suprema don José Alejo Valenzuela, quien no asistió nunca. Don Diego Armstrong, de asistencia irregular, fue Diputado suplente por Llanquihue y Osorno entre 1870 y 1873, y luego por Osorno, entre 1885 y 1888, pasando a ser titular en 1887. Don José Vicente Abalos Valderrama, por su parte, era miembro del poder Judicial y llegó a ser también Presidente de la Corte Suprema en 1891. Su reemplazante en la Comisión, don Adolfo Ibáñez, la integró después de su regreso al país desde una misión en el Perú, a fines de 1871, mientras ejercía el cargo de Ministro de Relaciones Exteriores del entonces Presidente Santa María.

Por lo tanto, la crítica que desde la obra de Fuenzalida, suele hacerse a la composición de esta Comisión Redactora, aduciendo que "el Código, con hombres especiales en la ciencia penal, pudo ser una obra mas perfecta", ${ }^{63}$ o en términos de Etcheberry, que ella "no estuvo integrada por juristas versados en la técnica penal, y en general las innovaciones introducidas se debieron a la influencia de las críticas de Pacheco", agregando que "las pocas que se deben a la originalidad de la Comisión Redactora no fueron muy felices", ${ }^{64}$ ocultan el hecho de que en la integración de la Comisión se tuvo en cuenta la idea de conformar una del más alto nivel posible en la sociedad de la época, cuyo prestigio y peso político se puso al servicio de lograr su concreción y aprobación, a pesar de los defectos técnicos que puedan atribuírseles. ${ }^{65}$

\footnotetext{
${ }^{63}$ FUENZALIDA, Código Penal, cit. nota $\mathrm{n}^{\mathrm{o}} 59$, p. $\mathrm{x}$.

${ }^{64}$ ETCHEBERRY, Alfredo, Derecho penal, parte general, t. I, $3^{a}$ ed. Revisada y actualizada, Santiago: Ed. Jurídica de Chile, 1997, 361 pp., p. 47, crítica reproducida en tono aprobatorio por RIVACOBA, Evolución, cit. nota $\mathrm{n}^{\mathrm{o}}$ 3, p. 42.

${ }^{65}$ Defectos que, con todo, no han impedido la vigencia hasta hoy en día del más que centenario texto punitivo nacional.
} 
MATUS, JEAN PIERRE. "La doctrina penal de la (fallida) recodificación chilena del Siglo XX y principios del XXI".

\subsubsection{La oportunidad política y la completitud del Proyecto de la Comisión Redactora de 1870}

Aunque pareciera una obviedad, no es un dato menor el que mientras el Código civil se formó y promulgó bajo el gobierno de una misma fracción política gobernante, la conservadora, con participación activa y personal en su última etapa del propio Presidente de la República; lo mismo ocurrió con el Código penal: iniciados los trabajos de la Comisión Redactora el último año del Gobierno Liberal de Prieto ( 8 de marzo de 1870), terminaron éstos el 22 de octubre de 1873, justo en la medianía del de su sucesor, Errázuriz (1871-1876), con tiempo suficiente para ser presentado ante al Congreso Nacional, como el propio Ministro de Justicia había requerido a los comisionados, según se lee en el acta de la sesión n ${ }^{\circ} 129$, de 2 de mayo de 1873 , en que:

“el Señor Reyes dió lectura a una nota pasada por el señor Ministro de Justicia, en que a nombre de S.E. el Presidente de la República, pide a la Comisión que arbitre un medio para activar sus trabajos, a fin de que puede el Código presentarse a la aprobación del Soberano Congreso, en las sesiones del año actual."

A partir de esta fecha, las sesiones comenzaron a realizarse diariamente, de lunes a viernes, y de siete a diez de la noche, terminando la Comisión su trabajo el 22 de octubre de 1873, en la sesión numerada como 175, pero que, en realidad, correspondía a la 174 , según demuestra Rivacoba. ${ }^{67}$

El Proyecto terminado contemplaba, amén de sus 504 artículos correlativos originales, un "artículo final", el cual, tras la discusión parlamentaria, fue promulgado con el siguiente tenor:

“ARTÍCULO FINAL. El presente Código comenzará a regir el primero de marzo de mil ochocientos setenta y cinco, y en esa fecha quedarán derogadas las leyes y demás disposiciones preexistentes sobre todas las materias que en él se tratan." 68

De este modo, el Proyecto y el Código en definitiva aprobado podían cumplir con la importante función de ser realmente una obra fijadora, da carácter "totalizador y comprensivo" y cuyo contenido, si bien normativamente recogía valoraciones de la legislación anteriormente vigente, expresaba "hacia el futuro el derecho vigente" en la materia. ${ }^{69}$

\subsubsection{La estabilidad socioeconómica en la República Liberal}

Finalmente, como ya dijimos, otra de las principales condiciones que Guzmán Brito estima podrían "garantizar" el éxito de una codificación, es la existencia de un "período de estabilidad socioeconómica -no necesariamente política- durante el cual el código

\footnotetext{
${ }^{66}$ Actas, cit. nota n ${ }^{\circ} 49$, sesión 129, p. 228. Este incidente, transcrito por RIVACOBA, Manuel, "Estudio Preliminar", en Código penal de la República de Chile y Actas de las sesiones de la Comisión redactora del Código penal chileno, Valparaíso: Edeval, 1974, 574 pp., pp. ix-lv, p. $x v$, junto con la existencia de importantes pausas durante el tiempo que la Comisión trabajó, de que también da cuenta este autor, contradice un poco la idea que él mismo afirma más adelante acerca de su supuesta "reposada gestación" (p. xxiii).

${ }^{67}$ RIVACOBA, Evolución, cit. nota n ${ }^{\circ} 3$, p. $44 \mathrm{~s}$.

${ }^{68}$ El texto aprobado por la Comisión fijaba como fecha de entrada en vigencia el primero de junio de 1874, pero hubo de ser modificada tras la reñida discusión parlamentaria, centrada, como ya vimos, en la disputa religiosa de la época (Vid. nota $\mathrm{n}^{\circ} 45$, y el texto a que hace referencia).

${ }^{69}$ GUZMÁN BRITO, La fijación, cit. nota ${ }^{\circ}$ 5, p. 24.
} 
sea elaborado y promulgado", y que un período de esta naturaleza, respecto del Código Civil, se vivió durante nuestra República Conservadora. ${ }^{70}$ No otra cosa se vivió durante la República Liberal, en cuya medianía apogeo se promulgase nuestro Código penal, pues, según Jocelyn-Holt,

“durante tres décadas al menos, hasta llegar a 1891, no se produjo ningún quiebre al interior del sistema político o de la elite dirigente. $\mathrm{Y}$ eso que hubo dos guerras internacionales, se sobrevivió la crisis económica de los años 70 , la más aguda hasta la fecha, se transitó a una sociedad marcada por crecientes niveles de urbanización, migraciones internas y expansión territorial. Se experimentó un gran cambio en el sistema económico a causa del salitre, alcanzándose las más altas tasas históricas de crecimiento."

\subsection{Resumen preliminar: las condiciones generales para una (re)codificación}

Aceptando como hipótesis de trabajo que los procesos históricos de fijación y codificación del Derecho son reiterativos y necesarios hasta cierto punto, ${ }^{72}$ hemos intentado en los apartados anteriores reconstruir las condiciones históricas de la codificación penal chilena de 1874 , cuya perdurabilidad es ejemplar y casi única, para poder evaluar a su luz las razones del fracaso de los proyectos (re)codificadores del siglo XX y la fortuna que pueda correr el del año 2005.

Desde luego, habremos de partir por afirmar que la mera pérdida aparente de unidad y coherencia ("crisis") del sistema normativo, debido únicamente a su supuesta "antigüedad" o, como señala Grisolía, por el sólo hecho del "transcurso del tiempo",73 desde la codificación dieciochesca, o por la "pérdida de plenitud" del texto original, como sostiene Etcheberry, ${ }^{74}$ no es, a mi modo de ver, una "condición" que haga "necesaria" una recodificación de ese material, como no sea ello un ejercicio puramente "técnico" o "académico", 75 pues es evidente que en límites tolerables, esa dispersión, contradicciones y falta de regulación de temas determinados, pueden ser funcionalmente suplidas con disposiciones específicas, tanto materiales como procesales, como se hizo

\footnotetext{
${ }^{70}$ Vid. nota $n^{\circ} 5$.

71 JOCELYN-HOLT, “El liberalismo moderado", cit. nota n 37, p. 448.

${ }^{72}$ Baste para ello la mirada histórica que a diversos procesos de fijación y codificación del derecho entrega GUZMÁN BRITO, La fijación, cit. nota n ${ }^{\circ}$ 5, pp. 91-119.

${ }^{73}$ GRISOLÍA, "La reforma penal", cit. nota al pie no 38 , p. 325.

74 ETCHEBERRY, Alfredo, "Centenario del Código penal chileno: ¿permanencia o caducidad?", en RIVACOBA, Manuel (Ed.), Actas de las Jornadas Internacionales de Derecho penal en celebración del centenario del Código penal chileno, Valparaíso: Edeval, 1975, 398 pp., pp. 373-379, p. 376.

${ }^{75}$ Esto es, una simple "fijación”, en los términos de GUZMÁN BRITO, La fijación, cit. nota no 5, p. 30s. Pero, como el propio GUZMÁN BRITO, percibe esta labor puramente técnica es algo que no requiere en caso alguno el impulso oficial, o, dicho de otra manera, es completamente independiente del sistema político, del cual depende, en última instancia, una verdadera (re)codificación, que haga congruentes las disposiciones formalmente vigentes con las valoraciones sociales acerca de lo permitido y lo prohibido y los mecanismos para hacerlas cumplir. En efecto, esta labor de fijación privada no es una condición necesaria para la fijación oficial, mediante un código, sino simplemente un hecho de la causa: las recopilaciones de leyes, jurisprudencia y opiniones doctrinales que dan cuenta del derecho vigente en una comunidad se encuentran habitualmente en los textos al uso en las clases universitarias y en el foro. Hoy en día, además, el accesos a las bases de datos informáticas permite también una consulta más o menos expedita de toda la normativa formalmente vigente, aún cuando no se disponga de toda la información que sería necesaria para ubicarlas, en caso de no contar con las ventajas de la digitalización.
} 
MATUS, JEAN PIERRE. "La doctrina penal de la (fallida) recodificación chilena del Siglo XX y principios del XXI".

en el Chile de las primeras épocas de la independencia y durante nuestra República Conservadora, sin pérdida de funcionalidad del sistema. ${ }^{76}$

En cambio, entre las verdaderas condiciones que permitieron la codificación penal de $1874,{ }^{77}$ y que, presumiblemente, podrían permitir una nueva (re)codificación, pueden contarse las siguientes:

1.4.1. Cambio más o menos pronunciado en las valoraciones sociales acerca de lo permitido y lo prohibido, en un marco de estabilidad social y política. ${ }^{78}$

Desde el punto de vista social, un Proyecto de nuevo Código penal sólo parece tener posibilidades de ser planteado y aceptado cuando se ha perdido la congruencia entre las valoraciones sociales y las del sistema normativo anterior $\mathrm{y}$, consecuentemente, cuando existe congruencia entre el verdadero sistema de valoraciones sociales y el del nuevo ordenamiento propuesto.

\footnotetext{
${ }^{76} \mathrm{La}$ arbitrariedad judicial que eventualmente podría justificarse en la existencia de un sistema de fuentes desordenado y de difícil acceso, como bien señalaba Portales, de existir, no es producto exclusivo de dicho sistema, sino del carácter de los jueces que la llegan a practicar (ver nota al pie $n^{\circ} 8$ ) y, por tanto, ni exige ni se soluciona únicamente con una codificación.

${ }^{77}$ El carácter histórico de esta investigación deja fuera de su alcance la discusión acerca de si, aparte de deseable, es necesario contar con una dosis importante de información empírica acerca del funcionamiento real de nuestro sistema penal para emprender una (re)codificación, más que sea para no establecer sanciones imposibles de ejecutar, risibles o absolutamente inútiles, como proponía Bascuñán en una sesión preparatoria del lanzamiento del denominado "Foro Penal", que culminó con la entrega del Anteproyecto de 2005, señalando que "una redefinición del Derecho Penal ciega a los datos empíricos es una empresa demasiado aventurada: su realización no sería signo de valentía sino de temeridad" (BASCUÑÁN R., Antonio, Observaciones sobre la Reforma del Código Penal (Intervención en la Jornada de Reflexión convocada por el Ministerio de Justicia el día Lunes 2 de Agosto de 1999), Documento inédito en mi poder, 8 pp., p. 5). Al respecto, lo único que puedo agregar es que el Código penal de 1874 se proyectó y aprobó careciendo de estudios empíricos e incluso de la noción misma de su posibilidad en el sentido actual, salvo lo que los comisionados podían conocer de mano propia en su experiencia como juristas o en las lecturas a que tenían acceso. Y a pesar de esta orfandad, ese Código así preparado rige hasta hoy en día.

También quedan fuera de discusión las elucubraciones acerca de la necesidad o no de reformar primero otros aspectos del sistema penal, como el proceso penal mismo y las condiciones de ejecución de las penas y otras medidas de ejecución penal, como las esbozadas por GRISOLÍA, "La reforma penal", cit. nota al pie $\mathrm{n}^{\mathrm{o}} 38$, pp. 327 ss., tanto por la base histórica que tomamos para nuestras afirmaciones, como por las siguientes constataciones de hecho:

a) Las reformas al procedimiento penal han sido, en Chile, completamente independientes del Código penal: el Código penal de 1874 se discutió y promulgó sin reformar el procedimiento inquisitivo español heredado, con las modificaciones que las leyes patrias le habían introducido; el Código Procesal de 1906 - también de corte inquisitivo - no requirió reformar el Código penal; y, salvo para adecuaciones puntuales de nomenclatura, tampoco lo exigió el Código Procesal Penal de 2000, que estableció un sistema oral y de corte acusatorio, como puede comprobarse consultado la obra de HORVITZ, Ma Inés; LÓPEZ, Julián, Derecho procesal penal chileno, t. I, Santiago: ed. Jurídica de Chile, 2002, 638 pp., pp. 19-24; y

b) Tampoco las reformas a los sistemas carcelarios y de ejecución de las penas han supuesto reformas directas al Código penal, aunque de hecho hayan modificado sus efectos y formas de ejecución, como puede verse en POLITOFF / MATUS / RAMÍREZ, Lecciones $P G$, cit. nota ${ }^{\circ} 16$, pp. 557ss.

${ }_{78}$ Quisiera ser absolutamente claro en que aquí, al hablar de "valoraciones sociales" me refiero a las decisiones acerca de lo permitido o no que sostiene aquella parte de la sociedad que forma una mayoría sustancial en ella, es destinataria de las normas que se trate, y tiene un poder real, directo o indirecto (como en nuestra democracias representativa), para influir en la formalización normativa de tales valoraciones y su aplicación y ejecución posterior.
} 
Un simple cambio de régimen político (aún de la mayor trascendencia, como ocurrió entre nosotros con la emancipación de España), en tanto no se traduce en un verdadero cambio perceptible en las valoraciones sociales no es suficiente para hacer viable una codificación penal que, necesariamente, ha de hacerse cargo de ellas para tener éxito. En el Chile del siglo XIX, una codificación penal, que en todos los modelos de la época se presentaba con un cariz más o menos liberal en lo político, no fue posible sino hasta la estabilización del paso de la República Conservadora de su primera mitad a la Liberal, de la segunda.

La acentuada congruencia entre los valores del liberalismo moderado prevaleciente en Chile en la segunda mitad del siglo XIX y los de la Escuela Clásica del Derecho penal española, ínsitos en el Código de 1848/1850, con su mezcla de liberalismo y pervivencia del derecho anterior y su orden social, permitió avanzar un poco más allá del "peso de la noche" en el ámbito de las valoraciones sociales.

Sin embargo, no por ello se evitó toda discusión al respecto. En efecto, contrariamente a cómo el Congreso había aprobado los restantes Códigos sustantivos, al discutirse allí el Código penal, las cuestiones en donde con mayor claridad se apreciaba el cambio de las valoraciones desde el Chile conservador de principios de siglo XIX al moderadamente liberal de su segunda mitad, suscitaron un intenso debate: las relaciones de la Iglesia y sus representantes con el Estado ocuparan la mayor parte de ellas, pero tampoco escaparon las relativas a la regulación de la vida familiar y sexual.

Por lo tanto, es evidente que si tales discusiones se producían en el siglo XIX, se volverán a presentar en cualquier época en que un Código sea discutido en el Congreso nacional, en la medida que existan grupos importantes en la sociedad con valoraciones divergentes sobre aspectos esenciales. El debate sobre esos aspectos estará presente sí o sí en el mundo político, cualquiera sea la posición que adopte el Proyecto en cuestión (e incluso, aún si no ofrece solución alguna) o tengan sus redactores, tanto si previamente las han debatido o no entre sí.

En consecuencia, las prevenciones que Bascuñán plantea, en el sentido de que una (re)codificación penal (hoy en día), no aceptaría la "astucia" de tratar de imponer las perspectivas políticas propias "bajo subterfugios conceptuales o técnicos", ni tampoco la de simplemente escabullir el bulto a las cuestiones acuciantes de la sociedad actual (finalidad misma del sistema punitivo, responsabilidad penal de las personas jurídicas, eutanasia, aborto, delitos contra el derecho penal internacional, el medioambiente, y económicos), ${ }^{79}$ deben entenderse como válidas en los siguientes sentidos: a) una (re)codificación penal puramente "técnica", esto es, destinada a la mera fijación formal del derecho del pasado $\mathrm{y} / \mathrm{o}$ a ofrecer soluciones de técnica legislativa a problemas puntuales, sin hacerse cargo de la vida política del país, es superflua; ${ }^{80}$ y b) un proyecto de (re)codificación cuyas decisiones valorativas apuntan en todos los casos o en la mayor parte de ellos en sentido completamente contrario al de las valoraciones sociales imperantes, no sería congruente con la sociedad a que se dirige, se deslegitimaría y no pasaría de ese estadio.

Finalmente, no debe olvidarse que este cambio de valoraciones, para reflejarse en un Código más o menos duradero, como el chileno de 1874, tiene que darse dentro de un

\footnotetext{
${ }^{79}$ BASCUÑÁN R., Antonio, Observaciones, cit. nota no 77, pp. 6 a 8.

${ }^{80}$ Véase la nota $\mathrm{n}^{\circ} 75 \mathrm{y}$ el texto a que hace referencia.
} 
MATUS, JEAN PIERRE. "La doctrina penal de la (fallida) recodificación chilena del Siglo XX y principios del XXI".

período de estabilidad socioeconómica, como lo fue el de la República Conservadora para el Código Civil, y el de la Liberal, para el de nuestra materia.

1.4.2. Compromiso político del Gobierno de turno con la reforma (oportunidad política), y de los miembros de la Comisión Redactora del Proyecto (calidad personal)

Así como la Codificación civil contó con la genialidad de Bello y el compromiso y participación activas del entonces Presidente Montt, en el caso de la codificación penal chilena, bastó con el compromiso efectivo de los Gobiernos a cargo, y de los miembros de la Comisión Redactora designada en 1870, que si no eran grandes humanistas como Bello, sí tenían al menos un enorme prestigio e importantes responsabilidades de Estado con las que avalaron su trabajo.

En efecto, al nombrar a sus integrantes, el ya casi saliente Gobierno Liberal de Pérez se comprometió verdaderamente con el objetivo propuesto y, no pudiendo contar con redactores dotados de la genialidad y erudición de Bello - las cuales, a decir verdad, no abundaban en esa época ni tampoco hoy en día-, contó, en cambio, con algunos de sus Ministros y funcionarios, todos políticos del más alto nivel, que ocupaban o llegaron a ocupar las más altas magistraturas, en el Poder ejecutivo, como Ministros de Estado; en el Congreso Nacional, como Diputados o Senadores; y en el Poder Judicial, como Ministros de sus Tribunales Superiores.

No menos compromiso con la Comisión Redactora mostró la siguiente administración, también Liberal, de Errázuriz, que no alteró sus miembros, a pesar de designar algunos como Ministros de Estado y en otros puestos relevantes. Además, la administración de Errázuriz se preocupó especialmente de que el Proyecto que se estaba estudiando se completase en tiempo y forma para poder ser presentado y tramitado ante el Congreso Nacional, mientras tuviese oportunidad de hacerlo, como efectivamente sucedió.

En la actualidad, el proceso de adopción de un nuevo sistema procesal penal de corte acusatorio, que reemplazó completamente a nuestro anterior sistema inquisitivo, es otro ejemplo de cómo, con independencia del trabajo "técnico" de los especialistas, éste no puede desencadenar por sí solo una reforma de envergadura, una (re)codificación, si no cuenta con un soporte político que recoja, de una manera u otra, una parte más que importante del conjunto de la sociedad. ${ }^{81}$

\footnotetext{
${ }^{81}$ Según HORVITZ/LÓPEZ, Derecho procesal penal I, cit. nota ${ }^{\circ}$ 77, p, 22, nota 17, "la alianza de dos instituciones no gubernamentales en la génesis de la [reforma], una vinculada a la Concertación (CPU) y la otra a la derecha (FPC), permitió un consenso político inédito en la historia del país". El proceso de elaboración del Código, ocupó la agenda del Ministerio de Justicia, durante el Gobierno de los Partidos por la Concertación Democrática del Presidente Eduardo Frei Ruiz-Tagle (1994-2000) y luego, su implementación, acordada tanto por el gobierno como por la oposición, quedó a cargo de su sucesor, de la misma coalición política, Ricardo Lagos.
} 
1.4.3. Consenso básico en los redactores y el estamento jurídico en torno al modelo legislativo y la obra de referencia del proyecto codificador, que recojan las nuevas valoraciones sociales $^{82}$

Como vimos, en el seno de la Comisión Redactora del Código de 1874, se formó rápidamente un consenso en torno a tomar como modelo la codificación española de 1848/1850 y, para su contraste y contar con información adicional, el Código penal concordado y comentado de Pacheco. En el caso de la Codificación Civil, todo ello se refería a los proyectos preparados por Andrés Bello, quien tenía a su vez de modelo principal la Codificación francesa y las obras de referencia de los más importantes autores franceses y españoles de la época.

En ambos casos, este consenso facilitó enormemente el proceso de discusión y redacción de los Códigos respectivos, al contarse con textos ya elaborados sobre los cuales centrar la discusión y recurrir para consultar soluciones normativas divergentes, sin que éste debiese partir ex nihilo, con la elaboración de materiales preparatorios de derecho comparado u otros más o menos complejos, que lo hubiesen retrasado enormemente. $^{83}$

\footnotetext{
${ }^{82}$ Luego, no nos referimos aquí a la simple existencia de eventuales acuerdos "dogmáticos" más o menos extendidos sobre aspectos "técnicos" o interpretativos de mayor o menor importancia "teórica", que no afecten las valoraciones sociales antes existentes acerca de lo prohibido y lo permitido y los medios de hacerlas cumplir. Tal clase de acuerdos, en vez de favorecer una reforma, la paralizarían, pues serían funcionales a la legislación vigente y no, como podría creerse, un acicate para su reforma. La "pax dogmática" (entre los dogmáticos y con las valoraciones sociales) y la idea de que la reforma penal consiste principalmente en la "aplicación de las mejores soluciones técnicas posibles" (GRISOLÍA, "La reforma penal”, cit. nota $\mathrm{n}^{\circ} 38$, p. 325), no conduce necesariamente a una reforma, sino a un acuerdo interpretativo independiente del texto legal, que no requiere una (re)codificación, como bien lo ha demostrado la larga vida de nuestro Código, "sin que hayan encontrado inconvenientes para adaptarse a él y reconstruirlo científicamente con arreglo a sus criterios las teorías y tendencias más avanzadas" (RIVACOBA, "Estudio preliminar", cit. nota al pie no 66, p. xxxii). En definitiva, es muy posible que esas cuestiones "dogmáticas" que se debaten al margen de los textos legales sean propias de aquellas doctrinas que ven en la elaboración dogmática una suerte de derecho natural (racionalista o no), que no se encuentra vinculado a decisiones legislativas, sino al contrario: exigen el acomodo de éstas o al menos de su interpretación a aquéllas, de manera que un texto positivo nuevo o antiguo ni guía ni les impide su desarrollo (véase al respecto, MATUS, Jean Pierre, La transformación de la teoría del delito en el Derecho penal Internacional, Barcelona: Atelier, 2008, 185 pp., pp. 65-67).

${ }^{83}$ Por lo tanto, la cuestión acerca del modelo de codificación, el "horizonte de referencia" que adoptemos, no puede consistir en una extensa colección de legislación, códigos y proyectos extranjeros; con su más extensa todavía colección correlativa de obras de referencia o epigonales, que permitan conocer los problemas que suscitan, sus dudas, dificultades y propuestas de solución. La propuesta de BASCUÑÁN, Observaciones, cit. nota al pie $\mathrm{n}^{\circ} 77, \mathrm{p}$. 5 s, en orden a tener en cuenta alguna legislación moderna aún no pertenecientes a nuestro ámbito hispano, para así lograr una "renovación de nuestro horizonte cognitivo", no es incompatible con lo que aquí se sostiene (aunque su fundamento histórico esté errado: el Código belga tuvo una marginal influencia en nuestra codificación decimonónica), pero sólo en la medida que ello se concrete en la elección de un número muy reducido de modelos legislativos, respecto de los cuales se cuente al menos con una obra comprensiva de referencia, que permita apreciar sus problemas interpretativos, vacíos y contradicciones, aportando ideas para su solución.

Estos requisitos no se cumplen si el conjunto de modelos es ajeno, abigarrado y disperso en sus orientaciones, con lo que el propósito de Bascuñán puede desembocar en una discusión paralizante, más aún si se toma en serio su propuesta de no considerar legislaciones latinoamericanas y ni siquiera tomar muy en serio el Código español de 1995; prefiriendo, en cambio, los proyectos alemanes e italianos de la segunda mitad del siglo XX, junto con los españoles que antecedieron al Código actualmente vigente. Pero esto no sólo es impracticable por las grandes diferencias técnicas entre todos ellos, sino porque, a pesar del buen propósito que anima a Bascuñán, tales proyectos tienen algunos ya más de 50 años (como el oficial alemán de 1962) y los más recientes, rondan entre los 30 y 40 años (como los españoles de las primeras legislaturas tras la muerte de Franco), representando, necesariamente, valoraciones sociales de
} 
Es, además, muy destacable que el criterio de la Comisión representaba también el consenso del estamento jurídico, que tenía por función la aplicación del derecho en el día a día, el cual, al menos en los primeros comentarios, recibió con elogios y sin discusión la elección tanto del modelo legislativo como de la obra de referencia para su comprensión. ${ }^{84}$

\subsubsection{Completitud del Proyecto}

No hay codificación o (re)codificación a medias. Se trata de una cuestión técnica de Perogrullo, pero que vale la pena destacar. Sin un Proyecto completo no es posible su revisión ni su presentación como tal al órgano legislador, como no fue posible en el caso del incompleto Proyecto de Carvallo. Reformas parciales son sólo eso, nada más, y en poco se diferencian de las leyes especiales que se dictaron durante la República Conservadora, completamente funcionales al sistema social y normativo de la época.

Pero no sólo eso: un nuevo Código penal, para ser tal, debería producir el efecto de fijar el derecho aplicable para el futuro, haciéndose cargo de todas las disposiciones penales antes en vigor, sea para su derogación orgánica total, como lo proponía el artículo final del Código de 1874, sea para indicar precisamente cuáles mantienen su pervivencia. ${ }^{85}$ De otro modo, el Proyecto, aunque "aparentemente" "completo", se incorporaría al sistema de fuentes ya existentes, como una más, perdiéndose, con ello la ventaja "técnica" de una codificación: la fijación del derecho vigente en un texto único, accesible y con disposiciones que guardan la mayor armonía posible entre sí. ${ }^{86}$

esa época en dichos países, las que, seguramente, han sido superadas en la legislación hoy vigente. Otra cosa es que tomando como modelo alguna de las (re)codificaciones más recientes, respecto de las cuales se tenga, además, un texto de referencia accesible para la mayor parte de la comunidad (lo cual, evidentemente, está limitado por las cuestiones idiomáticas), se tengan también en cuenta los textos que Bascuñán sugiere, como referencia para el caso de ser necesario contar con un modelo de solución técnica diferente.

${ }^{84}$ Aunque se sabe que en la última etapa de revisión del Proyecto de Bello se recibieron, además, observaciones de magistrados, políticos y juristas, las que se discutían junto con la labor de revisión del texto propiamente tal (ver, Supra, nota al pie $\mathrm{n}^{\mathrm{o}} 23 \mathrm{y}$ el texto a que hace referencia), este proceso estuvo completamente ausente de la codificación penal, sin que ello fuese óbice para su aprobación y perdurabilidad en el tiempo. Quizás ello fue compensado por la propia calidad de los integrantes de la Comisión o, sencillamente, se trata de un ejercicio que puede ser reemplazado por las obras de referencia donde las dudas y dificultades que el derecho vigente presente se manifiestan. Por lo tanto, la "cuenta secular" de las "dudas y dificultades que ocurren a los jueces y los vacíos que ellos notan en la inteligencia y aplicación de las leyes” que BASCUÑÁN, Observaciones, cit. nota $\mathrm{n}^{\mathrm{o}} 77$, p. 4, exige como condición, "que de no ser cumplida, conducirá al fracaso de la recodificación", mediante el encargo a cada juez y Ministro de Corte de la evacuación de un informe al respecto, y su posterior vertido en un texto final que los unifique, no tiene sustento en la experiencia histórica chilena.

${ }^{85}$ Parcialmente en contra, RIVACOBA, "Estudio preliminar", cit. nota $\mathrm{n}^{\circ}$ 66, p. xxi y s., quien, en atención a la interpretación que hace de la disposición final del Código vigente, entendiendo que derogaba la legislación anterior sólo respecto de las materias que contenía, parece no ver inconveniente en que la derogación del Código se reduzca a esto, subsistiendo el sistema de fuentes anterior.

${ }^{86}$ BASCUÑÁN, Observaciones, cit. nota $\mathrm{n}^{\circ} 77$, p. 2, se refiere a esta condición en términos algo más pretenciosos, señalando que de no hacerse cargo del derecho anterior, el "Código Penal nunca tendrá el efecto restaurador de la racionalidad sistemática del Derecho Penal chileno", pero su conclusión es la misma que la aquí expresada: “'Reformar' el Código Penal dejando subsistente todo el universo de delitos tipificados y sancionados en la legislación penal especial y extravagante sería el equivalente a que en el siglo [XIX] el Código Penal se hubiera aprobado dejando subsistente las leyes patrias, las Recopilaciones de leyes de Indias y de Castilla y hasta las mismísimas Leyes de Partidas, como una especie de norma supletoria de estas viejas leyes."

Sin contar la pérdida de tiempo que ello implicaría, no es claro, sin embargo, que los encargados de la (re)codificación requieran realizar por sí mismos o encargar a terceros la realización de una labor de 
Polit. crim. Vol. 5, No 9 (Julio 2010), Art. 4, pp. 143-206.

[http://www.politicacriminal.cl/Vol_05/n_09/Vol5N9A4.pdf]

\section{2. ¿Por qué fracasaron los proyectos de (re)codificación del siglo XX?}

\subsection{Los proyectos de la "política criminal" (positivista) de la "Comisiones de Magistrados" ${ }^{\$ 7}$ tras el derrumbe de la República Oligárquica (1891-1925)}

Según hemos expuesto anteriormente, el "positivismo" empezó a tener influencia en Chile a partir de fines del siglo XIX y ya hasta bien entrada la década de $1930 .{ }^{88}$ Sus críticas de fondo al sistema penal del Código de 1874, las resumía en 1916 Raimundo del Río: "no conseguir la finalidad de su fundación, i estar basada en principios científicos i filosóficos antiguos":

"La criminalidad se desarrolla; la reincidencia i la precocidad en los ajentes del delito son cada dia mayores; la lei es impotente para reprimirlas, aun para aminorarlas: manifestaciones son éstas que muestran claramente cuan infructuosos han sido los esfuerzos de las viejas escuelas de derecho penal para solucionar el problema" ${ }^{, 89}$

Y en 1932, Rafael Fontecilla, entonces Ministro de la Corte de Apelaciones de Valdivia, constataba todavía una idéntica situación:

"La bancarrota del sistema clásico es un hecho que no se discute. Ese regimiento de reincidentes y e multi-reincidentes que ambulan por las prisiones del país, es el

\footnotetext{
"redefinición exhaustiva de los contenidos normativos", mediante una "disciplinada tarea de investigación, recopilación y concordancias de toda la legislación penal especial y extravagante" (BASCUÑÁN, Observaciones, cit. nota $\mathrm{n}^{\circ} 77$, pp. 4), pues como ya hemos visto, esta es una labor de fijación privada previa del derecho vigente que se encuentra disponible para los que quieran consultar sin prejuicios la bibliografía al uso en las universidades y el foro, amén de las infinitas facilidades que ofrecen los actuales sistemas informáticos de los que Bascuñán parece desconfiar. Otra cosa es que se quiera afirmar que tales fijaciones privadas no existen o son insuficientes o no son del agrado de todos. Los dos primeros juicios son falsos en la realidad chilena donde existen textos universitarios más menos completos y actualizados y bases informáticas disponibles. La última, una cuestión de juicio que afecta otra de las condiciones que aquí señalamos para hacer posible la (re)codificación — la existencia de obras epigonales de referencia-, pero no la que aquí se discute.

Además, desde el punto de vista estrictamente histórico, dicho trabajo previo de fijación no se realizó en la codificación penal del siglo XIX, y Bello también lo descartó, recurriendo precisamente a las obras doctrinarias al uso en su época, especialmente las españolas y francesas, donde encontraba tanto el modelo técnico de redacción como el contenido de las disposiciones, pues estimaba que "en materia de legislación civil casi todo está hecho; y para lo que falta o lo que necesita de enmiendas tenemos abundantes materiales en las obras de los expositores. Sus disputas sus paradojas, sus aberraciones mismas no señalan como con el dedo las frases que el legislador debe aclarar, las cuestiones que importa dirimir, los puntos en que se echa de menos una regla para una mejor dirección de los particulares en sus negocios y de 1 judicatura en sus fallos" (El texto de Bello está reproducido en GUZMÁN BRITO, Historia, cit. nota $\mathrm{n}^{\mathrm{o}} 2$, p. 202).

${ }^{87}$ Así se refiere Abraham Drapkin a todos los proyectos anteriores a 1945, creyendo que se trababa de uno solo, en "Primera Sesión Plenaria" de la Comisión formada en ese año para la reforma del Código penal (Proyecto de Reforma del Código penal, Libro Primero, Santiago de Chile: Dirección General de Prisiones, 1946, 158 pp., p. 39. El calificativo es absolutamente verídico respecto de los Proyectos Ortizvon Bohlen y Erazo-Fontecilla, ambos de 1929, y parcialmente del Labatut -Silva de 1938, donde sólo Pedro Silva era magistrado en ese momento. Queda clara así, sin más, la escasa repercusión de estos proyectos y la completa desvinculación de sus redactores con respecto al mundo político, académico y social de entonces.

${ }^{88}$ MATUS, "Positivismo", cit. nota $n^{\circ} 55$. Sobre la influencia de la doctrina italiana en general en Chile, véase también CARNEVALI, "La ciencia penal italiana", cit. nota n 39 .

${ }^{89}$ DEL RÍO, Raimundo, El problema penal, Memoria de Prueba, Santiago de Chile: Imp. Universitaria, 1916, 104 pp., p. 3.
} 
MATUS, JEAN PIERRE. "La doctrina penal de la (fallida) recodificación chilena del Siglo XX y principios del XXI".

signo más elocuente de este estado de falencia científico-penal en que nos encontramos" $" 90$

"Pero ...", agrega,

“estamos acostumbrados a vivir, más de ambiciones políticas que de inquietudes científicas. Y por eso bien poco nos ha importado el problema penal, que es problema no sólo de defensa, sino también de redención y de amor.

Y aquí estamos: frente a un Código sin entrañas y que carece de armas de lucha contra el crimen"91

Esta "indiferencia" de la sociedad oligárquica y del sistema político al "problema penal" era la misma que se tenía ante la denominada "cuestión social" en general, ${ }^{92}$ lo que, en definitiva, originó su colapso al término de la primera presidencia de Arturo Alessandri Palma (1920-1925), con el surgimiento de un nuevo orden social, en que el Estado se hizo cargo de buena parte de la denominada "cuestión social", traducida en una nueva regulación laboral y en la creación de un Estado empresario y proveedor, pero manteniendo el control político en manos de la tradicional clase dirigente, básicamente mediante la cooptación de las clases medias, que encontraron un cauce de expresión política en nuevos partidos y coaliciones políticas. ${ }^{93}$ La supervivencia del orden social y de la clase gobernante mediante este arreglo institucional, que mantuvo el inquilinaje, el cohecho y el intervencionismo electoral, permite a algunos historiadores modernos calificar las convulsiones y transformaciones institucionales ocurridas a partir del año 1924 y hasta 1932 como "un orden en paréntesis", luego restablecido en la segunda Presidencia de Alessandri, el que iniciaría un período de "orden restablecido",

"caracterizado por la presencia en el Ejecutivo de alianzas construidas sobre la base de acuerdos y negociaciones entre cúpulas partidistas, mediadoras éstas de los intereses y demandas de los sectores sociales con mayor poder y capacidad de presión en el país." 94

\footnotetext{
${ }^{90}$ FONTECILLA, Rafael, El Código Penal Chileno ante las nuevas orientaciones de la Ciencia Penal, Santiago de Chile: Imp. Lagunas \& Quevedo Ltda., 1932, 41 pp., p. 10.

${ }^{91}$ Íd., p. 6.

${ }^{92}$ Así, lo mismo que mientras en la primera presidencia de Alessandri el Congreso retardaba el despacho de las más o menos urgentes "leyes sociales" (al punto que debieron esperar el "ruido de sables" de 1924 para ser aprobadas); una Comisión nominativa de Diputados, Senadores, Magistrados y profesores universitarios, nombrada por Decreto de 23 de Julio de 1921 del entonces Ministro de Justicia Armando Jaramillo para estudiar la reforma del Código penal, "en pos de la celeridad de los procesos judiciales", "no se reunió o lo hizo sin dejar rastro" (JIMÉNEZ DE ASÚA, Tratado I, cit. nota n 28, p. 1171). Los miembros de esta amplia Comisión, según informa RIVACOBA, Evolución, cit. nota al pie no 3, p. 101, nota 116, fueron: Isidro Salas, Ministro de la Corte Suprema; Fermín Donosos, Ministro de la Corte de Apelaciones de Santiago; Manuel Alonso Maira, profesor de Universidad; Senadores Alfredo Barros Errázuriz, Malaquías Concha y Armando Quezada; diputados Tomás Ramírez y Romualdo Silva; y el Subsecretario de Justicia, Jorge Gaete Rojas. Posteriormente se designó en reemplazo de Silva a Roberto Peragallo y se agregó a Ricardo Cabieses, profesor de Universidad.

93 PORTALES, Felipe, "Los mitos de la democracia chilena en torno al bicentenario", en Omnibus, Año 7, II (2006), en http://www.omni-bus.com/n7/chiledemocracia.html [visitado por última vez el 15.03.2010].

${ }^{94}$ CORREA S., Sofía; FIGUEROA G., Consuelo; JOCELYN-HOLT, Alfredo; ROLlE C., Claudio; VICUÑA U., Manuel, Historia del Siglo XX chileno. Balance paradojal, Santiago de Chile, Ed. Sudamericana, 2001, 428 pp., pp. 89-110 y 193.
} 
Polit. crim. Vol. 5, No 9 (Julio 2010), Art. 4, pp. 143-206.

[http://www.politicacriminal.cl/Vol_05/n_09/Vol5N9A4.pdf]

Ello explica en buena parte la naturaleza de los Proyectos de (re)codificación penal de este período y su destino por todos conocido, como veremos a continuación.

\subsubsection{Los proyectos de "política criminal” (positivistas) de la Dictadura de Ibáñez}

La Dictadura de Ibáñez (1927-1931), quizás "el primer Estado policial en Chile”, no sólo realizó una "profunda transformación en la organización del Estado" (creando muchas reparticiones que aún hoy perduran, como el Cuerpo de Carabineros, la Fuerza Aérea, la Tesorería General de la República, Superintendencias y la Contraloría General de la República, por mencionar algunas), sino que, al mismo tiempo empleó el poder en toda su dimensión, deportando y exiliando a todo quien consideraba opositor, incluyendo "parlamentarios de todos los partidos, miembros del Poder Judicial" e incluso al propio Presidente de la Corte Suprema. ${ }^{95}$

No parece casual, entonces, que en este contexto también en el Ministerio de Justicia de Ibáñez, a cargo de su entonces yerno, Osvaldo Koch Krefft, quien ocupó la cartera de Justicia entre el 24 de febrero de 1928 y el 28 de julio de 1930, pretendiera una reforma del Código penal, que se hiciera cargo del antes mencionado "Problema Penal", nombrándose al efecto, por medio del citado por Decreto $\mathrm{N}^{\circ} 1171$, de 21 de julio de 1928, una Comisión integrada por el Senador Alberto Cavero; el Diputado Samuel Guzmán; el Ministro de la Corte Suprema, Agustín Parada; el de la Corte de Apelaciones de Santiago, Eduardo Erazo; los magistrados del Segundo Juzgado del Crimen de Santiago, don Rafael Fontecilla, y del Tercero Civil, Pedro Ortiz; el Profesor de Clínica Neurológica, Hugo Lea-Plaza; y el abogado Alfredo Cañas O'Ryan. Sin embargo, como hemos dicho, esta Comisión se reunió una sola vez, lo que quizás refleja el desinterés por el tema (sobre todo de los miembros del Parlamento), quedando radicada la redacción del anteproyecto, primero en Pedro Ortiz (según decisión de la Comisión, la única vez que se reunió); y luego, por designación ministerial, en los también magistrados Erazo y Fontecilla. Ambos proyectos se entregaron el año 1929, pero sólo el último fue adoptado oficialmente. ${ }^{96}$

Como ya hemos dicho, en este período histórico, las ideas penales dominantes eran las del positivismo, lo que, desde el punto de vista historiográfico, se destaca como "coincidente" con "las ideas eugenésicas de "depuración" y "regeneración"” de la Dictadura, ${ }^{97}$ y explica el contenido de los proyectos elaborados.

Sin embargo, es más o menos claro que esa coincidencia ideológica se enfrentaba ante un momento histórico en que el arreglo en el orden social no involucraba grandes transformaciones en las valoraciones de lo prohibido y permitido y los medios para hacerlas efectivas; no se había decantado aún; como tampoco existía la "estabilidad socioecómica" que permitiese la discusión de un Código que lo reflejase. Es más, como es sabido, tras el auge de fines de los años 1920, la abrupta caída de la economía con la

\footnotetext{
${ }^{95}$ CORREA/FIGUEROA/JOCELYN-HOLT/ROLLE/VICUÑA, Historia, cit. nota n ${ }^{\circ}$ 94, p. 103.

${ }^{96}$ FONTECILLA, Rafael, La Pena (evolución natural, jurídica y técnica). Los Problemas Modernos y sus influencias en el Nuevo Derecho Penal Chileno, Santiago, Imp. Cisneros: 1930, 424 pp., p. 202, ello se debió a que la Comisión sólo alcanzó a reunirse una vez y, sin haber avanzado en las materias, el Ministro de Justicia, Sr. Koch, prescindió de la misma y encargó personalmente a los Srs. Eduardo Erazo, Ministro de la Corte de Apelaciones de Santiago y Rafael Fontecilla, Ministro de la Corte de Apelaciones de Valdivia, la elaboración del proyecto de reforma. Éste fue entregado al Ministerio a fines de 1929 y enviado al Congreso en Octubre de ese año, aunque sin llegar a discutirse en propiedad.

${ }^{97}$ CORREA/FIGUEROA/JOCELYN-HOLT/ROLLE/VICUÑA, Historia, cit. nota no 94, p. 103.
} 
MATUS, JEAN PIERRE. "La doctrina penal de la (fallida) recodificación chilena del Siglo XX y principios del XXI".

crisis de 1929 trajo urgencias que sobrepasaban todo intento de codificación, incluyendo la caída de la propia Dictadura de Ibáñez y los intentos más bien utópicos de establecer una "República Socialista" de muy breve duración.

A lo anterior, deberíamos agregar otras dificultades no menores en los aspectos técnicos de la confección de los mencionados proyectos de 1929, que, vistos en retrospectiva, carecían de toda posibilidad de reemplazar al todavía vigente Código de 1874.

\section{a) El proyecto Ortiz - von Bohlen}

Pedro Ortiz Muñoz (1893-1947) se licenció en Derecho en la Universidad de Chile con una breve memoria de prueba sobre la filiación ilegítima, ${ }^{98}$ iniciando una carrera judicial como Juez de Talcahuano en 1919.

Entre el año 1925 y principios de julio de 1928 residió en Santiago, como Juez del 3er. Juzgado Civil de la Capital. En este período se desempeñó, además, como asesor del entonces Ministro de Justicia, quien le nombró Ministro de la Corte de Apelaciones de Talca, pero relevándole de la obligación de asistir al Tribunal, durante el encargo de la Comisión.

Como reconoce en sus posteriores Nociones de Derecho Penal (1933), al momento de recibir el encargo de redactar un anteproyecto de Código penal, no contaba con ningún conocimiento específico en la materia, y "tuv[o] que reunir para el estudios las más conocidas obras italianas, españolas y francesas, que eran las únicas disponibles en nuestras bibliotecas". ${ }^{99}$ En esta búsqueda del conocimiento, pasó de la sugestión por las ideas positivistas en boga en ese entonces, al encantamiento con el Proyecto Alemán de 1927 y la dogmática alemana de ese entonces, representada por las obras de v. Liszt, Kramer y Frank, ${ }^{100}$ de cuya traducción se sirve al punto que, con justicia, Jiménez de Asúa califica estas Nociones de "calco del Tratado de Franz von Liszt", 101 lo que parece aplicable al conjunto de sus obras generales, con el mérito, si se quiere, de que el propio Ortiz Muñoz lo reconoce sin tapujos y con humildad. ${ }^{102}$ Eso sí, su apego a la dogmática alemana y el rechazo al positivismo lo mantuvo Ortiz Muñoz durante toda su carrera posterior como Profesor Universitario. ${ }^{103}$

\footnotetext{
${ }^{98}$ ORTIZ MUÑOZ, Pedro, La ilegitimidad y la ley de matrimonio civil; reformas necesarias, Santiago de Chile: Imp. Selecta, $26 \mathrm{pp}$.

${ }_{99}$ ORTIZ MUÑOZ, Pedro, Nociones Generales de Derecho Penal, t. I, Santiago: Nascimento, 1933, 226 pp., p. 5 .

${ }^{100}$ ORTIZ MUÑOZ, Nociones I, cit. nota no 99, pp. 6 y 8, donde señala: "las doctrinas que doy a conocer son las de von Liszt, van Calker y Frank, tres de los más eminentes hombres de la ciencia de Alemania". ${ }^{101}$ JIMÉNEZ DE ASÚA, Tratado I, cit. nota n ${ }^{\circ} 28$, p. 1181.

${ }^{102}$ ABARZA, René; MATUS, Jean Pierre (Prof. Guía), Pedro Pablo Ortiz Muñoz. Vida, obra e influencia en el Derecho penal chileno., Talca: U. de Talca (Memoria de Prueba), 2005, 55 pp., p. 53.

${ }^{103}$ Esta carrera comienza en el año 1936, cuando jubila como Ministro de la Corte de Apelaciones de Talca, para dedicarse en Santiago a la vida profesional y universitaria, ejerciendo como Profesor de Derecho penal en las Universidad de Chile y Católica hasta su fallecimiento. Su nombramiento como Profesor de Derecho Penal de la Universidad de Chile entre 1928 y 1930 puede explicarse por la naturaleza del Gobierno dictatorial al que servía y el encargo que se había hecho, de redactar un anteproyecto de Código penal. En este período posterior de producción científica, amén de una decena de artículos sobre variadas materias de parte general y especial, produjo otras obras generales, como sus Nociones de Derecho Penal, t. II, Santiago: Nascimento, 1937, 214 pp.; y Curso Breve de Derecho penal, común y militar, Santiago: Imp. Carabineros de Chile, 1947. Para los detalles acerca de sus obras y vida, véase ABARZA/MATUS, Ortiz Muñoz, cit. nota n 102.
} 
Su Proyecto, siguiendo las directrices del Proyecto Alemán de 1927, resultó, en palabras de Jiménez de Asúa, "demasiado fiel al modelo germánico, hasta en el lenguaje". ${ }^{104}$ Un ejemplo de esto último es el reemplazo de la expresión culpabilidad por "culpa" (art. 11)..$^{105}$

No obstante lo anterior, aunque quizás desde un punto de vista externo ello aparecería como algo, además, distante de las ideas positivistas en boga durante la Dictadura de Ibáñez, lo cierto es que, en el fondo, el apego al modelo alemán significó que el Proyecto Ortiz - von Bohlen incorporara las ideas de la escuela moderna alemana de "política criminal", fuertemente influenciada por el positivismo italiano, ${ }^{106}$ lo que se reflejaba en un sistema dualista de penas y medidas de seguridad, las que incluían el "internamiento en asilo" para el inimputable "siempre que la seguridad pública lo exigiese" (art. 56); el "internamiento en casos de temperancia y de toxicómanos", para los condenados por delitos cometidos en ese estado que "habitualmente ingirieren en exceso bebidas u otras sustancias embriagantes" (art. 57); el "internamiento en casa de trabajo" para los que "habitualmente" se dedican al "rufianismo o a otras actividades análogas" o, en todo caso, si "es necesario para constreñirlos al trabajo y acostumbrarlos a una vida ordenada" (art. 58); la "custodia de seguridad" indefinida para el reincidente condenado "como delincuente habitual peligroso para la seguridad pública" (art. 59); y la "vigilancia protectora" en libertad (art. 61). ${ }^{107}$

A esta particularidad "germánica" del Proyecto se añade otra no menos relevante: Ortiz y von Bohlen sólo redactaron la Parte General de los dos Libros relativos a los crímenes y simples delitos y las faltas, respectivamente, con el argumento de que "la parte especial, es del resorte exclusivo de la política criminal del legislador y sólo su redacción deberá estar sujeta a las reglas de la ciencia". ${ }^{108}$

Adicionalmente, como ya también hemos dicho, este proyecto no fue, en definitiva, auspiciado por el Gobierno, poniéndose término al encargo conferido a Ortiz Muñoz,

El mantenimiento de su apego a la doctrina alemana puede verse después en su artículo "Los Problemas de la Reforma Penal", Revista de Ciencias Penales, t. I (1935), p. 13-15, p. 15, donde enfrentado de nuevo al tema de la reforma penal, sugiere a los reformadores que "abandonen los prejuicios que los liguen demasiado al pretérito, pero que, al mismo tiempo, resistan con patriótica entereza a esa avalancha imprudente e irreflexiva que se llama avanzada", en abierta alusión al positivismo y sus variantes.

${ }^{104}$ JIMÉNEZ DE ASÚA, Tratado I, cit. nota n ${ }^{\circ} 28$, p. 1174.

105 "Art. 11. No es punible el que en el momento de la ejecución del hecho no es capaz de obrar con culpa".

${ }^{106}$ RÜPING, Hinrich, Grundriß der Strafrechtsgeschichte, 3. Auf., München: C.H. Beck, 1998, 137 pp., p. $87 \mathrm{~s}$.

${ }^{107}$ Si hubiese alguna duda acerca de lo apegado del texto de Ortiz-von Bohlen a su modelo alemán, permítaseme reproducir la descripción de Mezger acerca de las "medidas de seguridad y corrección" de los Proyectos alemanes de la década de 1920, y particularmente del de 1927, adoptado por el Reichstag en 1930: "los Proyectos alemanes siguen este dualismo de pena y medida de seguridad, esta "duplicidad" de las medidas de lucha contra el delito. Así, por ejemplo, el Proyecto de 1930, prevé como medidas preventivas del delito, situadas fuera de la pena, las siguientes: el establecimiento de curación y cuidado para inimputables y sujetos de imputabilidad disminuida (parágrafo 56), el asilo de bebedores para los alcohólicos (parágrafo 57), la casa de trabajo para los refractarios a él, etc. (parágrafo 58), la custodia de seguridad para los delincuentes habituales peligrosos (parágrafo 59), la vigilancia de protección (parágrafo 61), etc." (MEZGER, Edmund, Tratado de Derecho penal, t. II, $2^{a}$ ed. (1933), trad. J. RODRÍGUEZ MUÑOZ, Madrid: Ed. Rev. de Derecho Privado, 1949, 453 pp., p. 434.

${ }^{108}$ ORTIZ MUÑOZ, Nociones I, cit. nota $\mathrm{n}^{\circ}$ 99, p. 116. 
MATUS, JEAN PIERRE. "La doctrina penal de la (fallida) recodificación chilena del Siglo XX y principios del XXI".

mediante decreto de 2 de julio de 1929, al contarse ya con otro proyecto paralelo completo: el de Erazo-Fontecilla. ${ }^{109}$

En resumen, el Proyecto Ortiz-Von Bohlen, inconcluso, basado en un modelo cuyas fuentes y posibles obras de referencia no sólo eran desconocidas por la comunidad jurídica nacional, sino que, además, derechamente no existían en Chile en ese momento y cuyo acceso estaba fuertemente limitado por el idioma, ${ }^{110}$ difícilmente iba a encontrar apoyo político, tanto en la Dictadura que lo promovió como en el futuro, aún cambiando las condiciones sociales. Si a lo anterior sumamos el, hoy diríamos, "bajo perfil" de su autor principal, incluyendo su nulo peso político personal, su residencia en la provincia y su escasa producción científica a la época en que le correspondía defenderlo, puede comprenderse con facilidad el por qué, a pesar del "deber patriótico" que se impuso en su divulgación, no obtuvo por ello su consideración en los procesos de reforma posteriores.

\title{
b) El Proyecto Erazo-Fontecilla
}

Según relata Fontecilla, tras el nombramiento en 1928 de la Comisión formada al efecto por el Ministro de Justicia de la Dictadura de Ibáñez,

\begin{abstract}
"Como transcurriera un año sin que los trabajos hubieran avanzado lo conveniente, el Ministro de Justicia, prescindió de la Comisión nombrada y designó a don Eduardo Erazo P. y a don Rafael Fontecilla R., ministros de las Cortes de Apelaciones de Santiago y Valdivia, respectivamente, para que presentaran al Gobierno un proyecto de Código Pena.
\end{abstract}

La Nueva Comisión así formada, bajo la Presidencia del Ministro Sr. Koch, y en que cupo a don Eduardo Erazo, hoy Fiscal de la Exma. Corte Suprema, una brillante y concienzuda actuación, trabajó con tesón en la reforma. Así nació el Proyecto de Código Penal, enviado a fines del año 1929, al Congreso Nacional para su discusión." 111

\footnotetext{
${ }^{109}$ Según la Nota del Ministro de Justicia de 2 de julio de 1929, el Sr. Ortiz fue nombrado en una "subComisión" de la mencionada en la nota al pie anterior, "con el objeto de que presentase a la brevedad posible un ante - proyecto que sirviera de base para la discusión del proyecto definitivo". Para colaborar con Ortiz, se contrató al Magistrado alemán von Bohlen, pero como el Ministro recibiese de los Srs. Erazo y Fontecilla un anteproyecto completo, que, según explica en dicha Nota, "consulta en todas sus partes las nuevas orientaciones científicas en esta rama del Derecho", estimó que tal proyecto podía enviarse sin más al Congreso, sin someterlo a la Comisión, motivo por el cual el Gobierno resolvió "poner término a la Comisión constituida por el recordado decreto $\mathrm{N}^{\circ} 1.171$, de 21 de junio de 1928". Como es evidente, este Proyecto Ortiz-von Bohlen, no fue presentado al Congreso y ni siquiera se encontraba completo al momento de relevarse al Sr. Ortiz del encargo, pues consultaba únicamente una parte general, de la cual, con todo, dice el Sr. Ortiz, algunas disposiciones "se copiaron" en el Proyecto Erazo-Fontecilla. Estos antecedentes, junto con la transcripción de la Nota citada, se encuentran en ORTIZ MUÑOZ, Nociones I, cit. nota $\mathrm{n}^{\circ} 99$, pp.115s. y $157 \mathrm{~s}$.

${ }^{110}$ Con todo, a pesar de que no se conocieran suficientemente en ese momento en Chile las doctrinas alemanes, al menos Ortiz Muñoz no estaba solo ante un "ambiente totalmente conquistado por la Escuela Positiva, cuyos dioses Lombroso, Ferri y Garófalo, emitían destellos que deslumbraban y enceguecían a quienes pretendían recorrer en Chile la senda áspera del Derecho penal", como se señala en una reseña de su pensamiento hecha como homenaje póstumo (MONTERO SCHMIDT, Mario. "El pensamiento jurídico penal de Pedro Ortiz", Revista de Ciencias Penales, t. X, nº 2 (1948), p. 110 y siguiente), como puede verse en MATUS, "El positivismo", cit. nota n ${ }^{\circ} 55$, p. $187 \mathrm{~s}$.

${ }^{111}$ FONTECILLA, La pena, cit. nota ${ }^{\circ}$ 96, p. 202.
} 
Como ya dijimos, amén de la situación de anormalidad institucional que se vivía en la Dictadura de Ibáñez, que dificultaba enormemente cualquier iniciativa (re)codificadora, al año siguiente (1930), la situación en el país se centró en los efectos desencadenados por la crisis económica y el llamado "Congreso Termal", de escasa legitimidad representativa, por así decirlo, se encontró abocado a la solución de los acuciantes problemas que dicha crisis provocó en el país. ${ }^{112}$

Por lo tanto, ni el posterior reconocimiento personal de Rafael Fontecilla como penalista; ${ }^{113}$ ni el prestigio que pudiera derivarse de las excepcionales circunstancias en que él y el Sr. Erazo ascendieron a los escalafones superiores del Poder Judicial; ${ }^{114} \mathrm{ni}$ mucho menos el decidido apoyo que recibieran en un comienzo del entonces Ministro de Justicia, "hombre joven, dinámico e innovador", según Rivacoba, ${ }^{115}$ fueron suficientes para contrarrestar la situación social reinante, que dificultaba de sobremanera la discusión política de un nuevo Código penal.

En tal ambiente social, tampoco fue suficiente para el éxito del Proyecto el que estuviese completo y que, al menos en sus fundamentos, aceptase como "un verdadero dogma del Derecho Penal moderno" el lema positivista entonces en boga: "no hay delitos sin delincuentes"; ${ }^{116}$ su reconocimiento de que "de las diversas direcciones

${ }^{112}$ CORREA/FIGUEROA/JOCELYN-HOLT/ROLLE/VICUÑA, Historia, cit. nota no 94, p. 105s.

113 Al igual que Ortiz Muñoz, Fontecilla era al momento de ser designado miembro de la Comisión Redactara, Juez de Letras, aunque en lo Criminal de Santiago y en el importante Segundo Juzgado de la época. Su reconocida dedicación, capacidad y sagacidad como Magistrado e investigador criminal compensaban, con todo, el hecho de que al año 1928 no se le conociese ninguna obra escrita en la materia, aunque sí había asumido una Cátedra provisionalmente en la Universidad de Chile, durante el agitado 1927. En efecto, su memoria de prueba trató del Estudio sobre las expropiaciones por causa de utilidad pública, Santiago: Imp. Bellavista, 1914, 46 p.; y su primera obra penal fue el texto en el que publica y fundamenta el Proyecto que elaborase para la Dictadura de Ibáñez (La pena, cit. nota $n^{\circ} 96$,). Posteriormente, publicó importantes artículos en revistas chilenas y extranjeras, libros de la especialidad y un impresionante tratado de Derecho Procesal Penal, en dos tomos, en las cuales demostraba su conocimiento y dominio de los idiomas italiano, francés y alemán; se reincorporó a la Universidad de Chile como Profesor en 1957 y llegó a ser Ministro y Presidente de la Corte Suprema de Justicia. Sobre la vida y obra de Rafael Fontecilla, véase CABELLO, Carlos; MATUS, Jean Pierre (Prof. Guía), Rafael Fontecilla Riquelme, vida, obra e influencia en el Derecho penal chileno, Talca: U. de Talca (Memoria de Grado), 2005, 65 pp.

${ }^{114}$ Recuérdese que, sin perjuicio de su méritos personales, como puede verse, especialmente respecto de Fontecilla en la nota anterior; sus designaciones y ascensos judiciales en un período de destituciones y destierros a voluntad del Dictador, parecen indicar no sólo el hecho de que el régimen no los considerase "problemáticos", sino, además, su adecuación a las directrices del mismo. No menos compromiso con la Dictadura parecía mostrar Eduardo Erazo Paredes: siendo Juez del Cuarto Juzgado de Letras de Valparaíso, fue ascendido a Ministro de la Corte de esa ciudad en abril de 1927, pasando el año siguiente a desempeñar igual cargo en la Corte de Apelaciones de Santiago. En esa calidad, integró no sólo esta Comisión de Reforma del Código Penal, sino también las creadas por el Ministro Koch para reformar la Ley de Organización y Atribuciones de los Tribunales y el Código de Procedimiento Civil. Finalmente, Ibáñez lo ascendió a fiscal de la Corte Suprema en junio de 1930, cargo en el que jubiló en 1945 (RAMÓN, Armando de (Ed.), Biografías de chilenos, vol. II, Santiago: Ed. Universidad Católica de Chile, 1999, 269 pp., p. 54s.).

${ }^{115}$ RIVACOBA, Evolución, cit. nota n ${ }^{\circ} 3$, p. 87. En todo caso, tal apoyo parece que no pasó más allá de la presentación al Congreso del Proyecto, en el cual, tras alguna discusión inicial en una comisión mixta formada al efecto, se paralizó, a nuestro juicio, producto de las condiciones sociales de la época; aunque, con cierta amargura e ingenuidad, Fontecilla lo atribuye al "sueño de nuestra inercia científica" (FONTECILLA, El Código Penal, cit. nota n ${ }^{\circ}$ 90, p. 6, nota 2).

${ }^{116}$ Como ya hemos dicho, el influjo positivista en Fontecilla era en ese entonces innegable. De hecho, todo el texto que antecede al del Proyecto está basado, como se señala en su "Advertencia", en "el Programa que Enrico Ferri acostumbraba a desarrollar en su Cátedra de la Universidad de Roma”, y sus 
científico-penales la que lo ha influido más hondamente es la política criminal", la misma que influyó tan significativamente en el del Ortiz-von Bohlen; ${ }^{117}$ ni la generalizada aprobación del texto por los autores extranjeros a que se les hizo llegar y respondieron al pedido de su estudio. ${ }^{118}$

Técnicamente, el Proyecto constaba de 341 artículos, divididos en tres libros, más un artículo final derogatorio. En el Primer Libro, denominado "Disposiciones Generales" se contienen las propuestas penológicas del Proyecto, que incluyen no sólo las atribuidas a la escuela de "política criminal" para reducir las penas cortas de prisión (condena condicional, perdón judicial, y un uso extensivo de la multa); sino también una introducción del "estado peligroso", como fundamento para la imposición preventiva de medidas de seguridad a "casos de peligro no constitutivos de delito", reservando - teóricamente - la clásica responsabilidad penal para los imputables, ${ }^{119}$ en un sistema aparentemente "vicarial", pero consagrando, en realidad, un sistema "dualista", pues se encontraba matizado fuertemente por la introducción de la sentencia indeterminada en los casos de imputables reincidentes (art. 30), lo que sencillamente borra la distinción entre "pena" y "medida de seguridad". También la distinción propuesta por el Proyecto queda en entredicho, cuando en el artículo 55 se califica como en "estado peligroso" y, por tanto, susceptibles de medidas de seguridad ("internamiento en manicomios u hospicios, establecimientos de reeducación, casas de salud, casas de trabajo"; "expulsión del extranjero"; "caución de buena conducta"; y "sujeción a la vigilancia de la autoridad", art. 56), no sólo a los "alienados mentales", los "inimputables", "los que observen una conducta desarreglada o viciosa", "los que vivan o se beneficien ordinariamente del comercio carnal", "los que tuvieren el hábito del juego", "los que practiquen el homosexualismo", "los vagos y toxicómanos"; sino también a los "afectos a responsabilidad disminuida" y a "los mendigos, ebrios y delincuentes crónicos."

tres primeras citas, corresponden en este orden, a Garófalo, Ferri y Garófalo (FONTECILLA, La pena, cit. nota $n^{\circ}$ 96, pp. 3-6). Sin embargo, ya en una Conferencia dictada diciembre de 1931 Fontecilla, como recién asumido Ministro de la Corte de Apelaciones de Valdivia, funde como fundamentos de su crítica al Código penal vigente, al que tilda de "oprobio para la ciencia contemporánea", ubicándolo "al nivel del Derecho Penal de hace doscientos años" sobre cual gravita "un fárrago de doctrinas inútiles", las citas a Liszt son numerosas y fundamentan el reclamo del autor por un Derecho penal de la "defensa social", donde "la pena no era más que un medio de defender a la sociedad" (FONTECILLA, El Código Penal, cit. nota $\mathrm{n}^{\circ}$ 90, pp. 5, 6, 12 y 19). Posteriormente, según RIVACOBA, "Estudio preliminar", cit. nota $\mathrm{n}^{\circ}$ 66 , p. xxvii, ya en 1974, "el docto jurista ha modificado profundamente sus juicios de otrora y se complace en reconocer y proclamar las excelencias del Código".

${ }^{117}$ MINISTERIO DE JUSTICIA, Proyecto de Código penal, Santiago: Imp. Nacional, 1929, 123 pp. y un "Mensaje" numerado en romanos, p. iv. La ácida crítica de ORTIZ MUÑOZ, Nociones I, cit. nota $\mathrm{n}^{\circ}$ 99, p. 115, confirma esta declaración, cuando señala que "los autores del Proyecto de Código Penal que el Gobierno envió al Congreso", "copiar[o]n algunas disposiciones del proyecto de Von Bohlen y de Ortiz, introduciendo en ellas algunas modificaciones de redacción que perjudicaron la claridad de los conceptos y la armonía que entre ellos debía mantenerse". Por su parte, CUELLO CALÓN, "El proyecto del Código penal chileno", Revista General de Legislación y Jurisprudencia, t. 157, n 1 (1930), señala que "nótanse en el este Proyecto muy marcadas influencias del alemán de 1927 y del suizo de 1918; el influjo de aquél es manifiesto en el libro primero, mientras que el de éste aparece en el libro segundo" (el artículo citado está transcrito completo por el propio FONTECILLA, La pena, cit. nota nº 96, pp. 399-417).

118 Estas opiniones, de los profesores Eusebio Gómez, Ladislao Thot, Mariano Ruiz Funes, Joseph Magnol, Luis Jiménez de Asúa, y el antes citado Cuello Calón, las reproduce el propio FONTECILLA, La pena, cit. nota $n^{\circ} 96$, pp. 384-417. Más tarde, el propio JIMÉNEZ DE ASÚA, Tratado I, cit. nota $n^{\circ}$ 28, p. 1172s., al referirse a este Proyecto señala que le parecía "de buena factura y correcto estilo" y merecedor de "sinceros plácemes".

${ }^{119}$ Proyecto 1929 , cit. nota $\mathrm{n}^{\circ} 117$, pp. $i v-i x$. 
En su Parte Especial, ("Libro II"), se innova la sistemática del Código de 1874, empezando "con los delitos que afectan a las personas, enseguida al patrimonio y después al Estado y empleados públicos", lo que se justifica en el Mensaje, diciendo que "este ha sido el orden seguido por casi todos los Códigos recientemente promulgados". Además, el quebrantamiento de condena pasa del Libro I a ser un párrafo especial dentro del Título XVII ("Delitos contra la administración de justicia"), a continuación del que castiga el "encubrimiento", también como delito especial (arts. 295 a 300). Por otra parte, se propone la supresión del delito de adulterio ("para dejarlo donde precisamente debe estar: en el orden moral") y de buena parte de los delitos formales relativos al estado civil (matrimonio de la viuda antes de plazo, casamiento sin consentimiento). En cambio, se estima necesario introducir los nuevos delitos de contagio venéreo y nutricio, "ligados al mejoramiento de la raza" (arts. 96 a 99); uno de peligro común relativo a las construcciones realizada con inobservancia de las reglas del arte (art. 188); el delito de sustracción de expedientes (art. 157); la coacción como delito independiente (art. 120); y el maltrato de niños (art. 104), entre otros. ${ }^{120}$

2.1.2. El proyecto "ecléctico" de Labatut-Silva (1938), al término de la segunda presidencia de Alessandri (1932-1938)

El 11 de junio de 1937, por Decreto No 2696 del entonces Ministro de Justicia, el miembro del Partido Radical don Alejandro Serani Burgos, quien había escrito su memoria de grado sobre un tema de Derecho penal, ${ }^{121}$ se encargó nominativamente a Gustavo Labatut, entonces Profesor Titular de Derecho Penal de la Facultad de Derecho de la Universidad de Chile, ${ }^{122}$ y a Pedro Silva, Ministro de la Corte de Apelaciones de Santiago, ${ }^{123}$ la redacción de un Proyecto de Código penal. ${ }^{124}$

\footnotetext{
${ }^{120}$ Proyecto 1929, cit. nota $\mathrm{n}^{\mathrm{o}}$ 117. Para mayores detalles del contenido del Proyecto, véase RIVACOBA, Evolución, cit. nota $\mathrm{n}^{\circ} 3$, p. $87 \mathrm{~s}$.

${ }^{121}$ Teoría de la investigación de los delitos, Santiago: imp. Escuela Secundaria de Anormales, 1928, 75 pp. En: RAMÓN, Armando de (Ed.), Biografías de chilenos, vol. IV, Santiago: Ed. Universidad Católica de Chile, 2003, 321pp., p.128s.

${ }^{122}$ Una exposición de su vida y obra, no completamente lograda, puede verse en ESPINOZA H., Mauricio; MATUS, Jean Pierre (Prof. Guía), Gustavo Labatut Glena: vida, obra y aporte al Derecho penal actual, Talca: Memoria de Grado U. Talca, 2005, 65 p. en el plano científico, como Fontecilla, Labatut transitó desde el positivismo italiano y la escuela de Política Criminal a la dogmática más neutra de la "Escuela técnica jurídica italiana". Así, mientras en su Manual de Derecho penal. Santiago: s/e, 1948, 551 pp., Labatut habla, siguiendo a Ferri, de que "hoy en día se considera a la escuela clásica en completa bancarrota, porque ha sido impotente para contener el aumento de la criminalidad, especialmente en dos de sus formas: reincidencia y delincuencia infantil" (p. 46) y afirma, junto a los positivistas, que "el delito es fundamentalmente un hecho del hombre que se realiza en el seno de la sociedad" (p. 47) y llama a Lombroso, ya desmitificada su tesis del "criminal nato", "el verdadero creador del derecho penal moderno, porque a él se debe la idea de sistematizar las investigaciones penales tomando como punto de partida la persona del delincuente, que es una realidad, en sustitución de la abstracción del delito" (p. 20); ya en el prólogo de la Tercera Edición considera los párrafos que antes dedicara a la criminología y la escuela positivista "de importancia secundaria", mostrando una marcada inclinación por la "escuela técnico-jurídica", que "depura al derecho penal de las infiltraciones filosóficas con que los clásicos la desvirtuaron, y de las concepciones biosociológicas de los positivistas" (LABATUT, Gustavo, Manual de Derecho penal, t. I. $3^{a}$ ed., Santiago: Ed. Jurídica de Chile, 1958, 480 pp., p. 13.

${ }^{123}$ Un retrato de la figura de Pedro Silva como magistrado, carrera en la que llegaría a ser Presidente de la Corte Suprema en 1963, ya que como penalista pocas son las obras que publicó, salvo el Proyecto que estudiamos y la que se citará Infra, nota al pie $n^{\circ} 130$, puede verse en la publicación del INSTITUTO DE CIENCIAS PENALES, Evocación de procesos penales olvidados, discurso de incorporación del Académico D. Pedro Silva Fernández y Discurso de recepción de D. Arturo Alessandri Rodríguez, Santiago: Ed. Andrés Bello, 1966, 20 pp., donde éste le atribuye una "capacidad intelectual poco común,
} 
MATUS, JEAN PIERRE. "La doctrina penal de la (fallida) recodificación chilena del Siglo XX y principios del XXI".

Este encargo tuvo como fruto un Proyecto entregado al sucesor en el cargo del Sr. Serani, desde agosto del mismo año 1937, el Sr. Guillermo Correa, del Partido Liberal, quien asumió tras el alejamiento de los radicales del gobierno de Alessandri. ${ }^{125}$ Aunque, en general, estábamos en lo inicios de la consolidación del nuevo orden creado después de las convulsiones de la década de 1920, lo cierto es que la reforma penal parecía ser un proyecto personal del Ministro Serani, pues su sucesor no le dio curso y el proyecto quedó archivado con el cambio de Gobierno de 1938 y la asunción de la nueva coalición política, el "Frente Popular", que con la incorporación de comunistas, socialistas y radicales, vino a terminar con la participación en el gobierno de los antiguos partidos liberal, democrático y conservador, que apoyaban al candidato Ross, Ministro de Hacienda del segundo gobierno de Alessandro.

Muy indicativo de la escasa importancia que a la reforma penal le asignaba el propio Alessandri, es su discurso con motivo a su incorporación como Miembro Académicos de la Facultad de Ciencias Jurídicas y Sociales de la Universidad de Chile, el 8 de julio de 1943, titulado "Nuestro Derecho en el Siglo XX", donde en el capítulo dedicado a los "Códigos chilenos y sus reformas" sólo hace mención de las reformas hechas a (una reorganización administrativa, propia de la época, por cierto), mencionando al Código penal sólo una vez, como una obra hecha y concluida en el Siglo XIX, de la cual no se preocupó, como sí lo hizo respecto de la creación de la legislación laboral y el Código del Trabajo (la respuesta jurídica a la "cuestión social"), así como de la reorganización administrativa de los Tribunales de Justicia, mediante la transformación en el Código Orgánico de Tribunales, de la Ley de Organización y Atribuciones de los Tribunales de $1875 .^{126}$

Por tanto, a pesar de encontrarse completo, el Proyecto Labatut-Silva, huérfano de apoyo político, y con un cambio de Gobierno ad portas, quedó depositado, junto con la breve nota que lo acompañó, en los archivos del Ministerio de Justicia.

En cuanto a su contenido, en palabras de sus redactores,

"El proyecto representa un progreso apreciable en nuestra legislación sustantiva penal, si bien mantiene en algunas materias el sistema del actual Código.

La Comisión Redactora, aún a riesgo de suscitar las críticas de los prosélitos de distintas escuelas penales, ha aplicado un criterio mixto o ecléctico, y ha elaborado un texto que está en consonancia con los principios generalmente admitidos por la doctrina y la legislación penal modernas hasta los extremos que han parecido compatibles con la idiosincrasia nacional, con las posibilidades de nuestro orden

\footnotetext{
vastos conocimientos jurídicos, ecuanimidad, serenidad de juicio e independencia de carácter para prescindir de las pasiones y de las convenciones e influjos de toda índole" (p. 17).

${ }^{124}$ La Nota con que se remite el Proyecto al Ministerio y los antecedentes transcritos, así como el Proyecto íntegro se encuentran en el t. IV (1938) de la Revista de Ciencias Penales, pp. 79-192.

${ }^{125}$ CORREA/FIGUEROA/JOCELYN-HOLT/ROLLE/VICUÑA, Historia, cit. nota $\mathrm{n}^{\circ}$ 94, p. 124s.: el alejamiento de los radicales del Gobierno de Alessandri, se debió a la formación del "Frente Amplio", a mediados de 1937, con el propósito de presentar un candidato único a las elecciones presidenciales de 1938, y al creciente descontento de este partido con "la política represiva" de Alessandri.

${ }^{126}$ ALEESANDRI PALMA, Arturo, Recuerdos de Gobierno, Administración 1932-1938, t. III, Santiago de Chile: Ed. Nascimento, 1967, 592 pp., p. 385.
} 
financiero y administrativo, con los deficientes medios de investigación de que disponen, con la escasa especialización de éstos en materia penal, etc."127

No obstante, según Jiménez de Asúa, "lo cierto es que el Proyecto Silva-Labatut no es más que una modificación" del Código de 1874, donde se mantiene el sistema de penas y sus "escalas graduales" (arts. 43 y 53), "la novedad" es "hacer responsables criminalmente a las "personas jurídicas"” (arts. 93ss). ${ }^{128}$ Un juicio similar, aunque más benevolente, tiene Grisolía, para quien el Proyecto Silva-Labatut "es, en verdad, una revisión bastante intensa en algunos sentidos, del Código vigente, pero sin romper en ningún caso la estructura de éste". ${ }^{129}$

Sin embargo, lleva más razón Grisolía que Jiménez de Asúa, pues el proyecto contempla más novedades que la sola introducción de la responsabilidad penal de las personas jurídicas, muy discutida en su época ${ }^{130}$ y que debió esperar hasta el año 2009 para ser una realidad normativa en Chile. ${ }^{131}$

En primer lugar, aunque conserva el sistema de escalas graduales y similares penas al Código de 1874, incluyendo la de muerte, introduce, conforme a la tendencia positivista del momento, un sistema dualista de "medidas seguridad y corrección", ${ }^{32}$ que salvo denominaciones y modalidades específicas, no difiere sustancialmente de las ideas de los Proyectos de 1929: se establece el "internamiento" indefinido en manicomio, hospicio u "otro establecimiento adecuado", tanto para el inimputable como para el condenado con "imputabilidad disminuida", que sea "peligroso para sí o los demás", hasta que se "declare desaparecido el peligro" (art. 59). El "internamiento" indefinido también es aplicable, "en casas de salud", a los condenados "alcohólicos o toxicómanos crónicos o dipsómanos" (art. 61). El "reincidente que haya sido condenado anteriormente más de tres veces y manifieste inclinación al delito, a la vagancia o a la mendicidad" (art. 63), puede ser también internado indefinidamente, "en casa de trabajo o en una colonia agrícola". Sólo los que sean únicamente "vagos o mendigos" están sometidos a medidas de seguridad temporales, salvo que posteriormente vuelvan a esa condición (arts. 64 y 65). Y para los imputables no sujetos a estas medidas, se propone determinar la pena "teniendo en cuenta el grado de peligrosidad que revela el delincuente" (Art. 44); especialmente para hacer las rebajas y aumentos por atenuantes y agravantes "que denotan, respectivamente, que el delincuente no es peligroso o que lo es" (Art. 47); e incorpora la institución de la "condena de ejecución condicional" (art. 76), esto es, la suspensión e la condena para los "no peligrosos"; y el cumplimiento progresivo de las penas, la "libertad condicional", ya antes introducido al sistema penal por el DL 321 de 1925.

\footnotetext{
${ }^{127}$ LABATUT, Gustavo; SILVA, Pedro, "Nota", Revista de Ciencias Penales, t. IV (1938), pp. 79-192, p. $79 \mathrm{~s}$.

${ }^{128}$ JIMÉNEZ DE ASÚA, Tratado I, cit. nota no 28, p. 1174s.

${ }^{129}$ GRISOLÍA, "La reforma penal", cit. nota $\mathrm{n}^{\circ} 38$, p. $318 \mathrm{~s}$.

130 Véase, en su defensa, el texto de SILVA FERNÁNDEZ, Pedro, "La responsabilidad penal de las personas jurídicas", Revista de Ciencias Penales, t. IV (1938), pp. 317-329.

131 Sobre los orígenes y fundamentos de la actual legislación en la materia (Ley $N^{o} 20.393$, de 02.12.2009), véase MATUS, Jean Pierre, "Presente y futuro de la responsabilidad penal de las personas jurídicas por los delitos cometidos por sus directivos y empleados", Revista de Derecho del Consejo de Defensa del Estado, № 21 (2009), pp. 47-68.

${ }^{132}$ Una detallada exposición de estas medidas, puede verse en LABATUT, Gustavo, "La peligrosidad de las personas naturales en el Proyecto de Código Penal Chileno," Revista de Ciencias Penales. t. IV (1938), pp. 289-296.
} 
Por otra parte, aunque conserva la estructura y contenido principal de las eximentes, atenuantes y agravantes, contiene este Proyecto también novedades de carácter "dogmático" o "técnico", como el reemplazo de la división tripartita de crímenes, simples delitos y faltas, por una bipartita (delitos y faltas); la ampliación del "estado de necesidad" a cualquier menoscabo o destrucción de "un derecho" de otro (art. 20, $\mathrm{n}^{\circ} 8$ ); la creación de un delito autónomo de "encubrimiento" (art. 302); la supresión de la figura del delito "frustrado", restando sólo la tentativa y la consumación (art. 5\%); la exclusión expresa de la punibilidad de la "tentativa imposible", pero permitiendo, en su caso, imponer medidas de seguridad, "según el grado de peligrosidad del sujeto" (art. $6^{\circ}$ ). Y, en la parte especial, mantiene en buena medidas las innovaciones en cuanto a la ordenación de los Títulos del Libro II del Proyecto Fontecilla — Erazo, y también en cuanto a la tipificación de muchos de ellos, aunque no siempre con igual fortuna, como aparece al menos respecto de los delitos contra la propiedad, cuya redacción fue fuertemente criticada en su época, ${ }^{133}$ al contrario que las propuesta relativas a los delitos de aborto, violación, incesto, estupros, abusos deshonestos y a la "explotación del libertinaje" (arts. 176 a 179), favorablemente acogidas. ${ }^{134}$

Con todo, estas innovaciones dentro de una reforma o revisión relevante del Código de 1874 en un proyecto completo, que técnicamente pudo someterse a discusión, como ya se dijo, no encontraron apoyo político, a pesar de la "moderación" en las propuestas innovadoras que contenía; pues, en verdad, al términos de una administración desgastada políticamente, con un nuevo Ministro de Justicia y el anterior en el bando opuesto del saliente Presidente, personalmente sin interés alguno de la materia, otra cosa no se podía esperar.

2.1.2. La adecuación de la legislación penal al arreglo institucional. Reformas parciales del segundo cuarto del siglo XX

Al igual que con la emancipación del régimen colonial, el nuevo arreglo institucional creado a partir del derrumbe de la República Oligárquica en 1925, supuso una serie de reformas en la legislación penal y en el Código, que permitieron adecuar el sistema penal al nuevo orden, sin necesidad de una trasformación radical del mismo o una (re)codificación, acogiendo parcialmente las ideas positivistas en boga funcionales al mismo y, al mismo tiempo, dando lugar a tipificaciones acordes con las necesidades de control en los nuevos campos de intervención estatal.

Así, en cuanto a las ideas positivistas y de la escuela de "política criminal" que inspiraron los proyectos de 1929 y el de 1938, éstas se reflejaron parcialmente en la exclusión de los menores de edad del sistema penal, mediante la Ley $N^{\circ} 4.447$, de 1928, sobre Protección de Menores y sus sucesivas modificaciones; el Decreto Ley No 321 , que estableció formalmente un régimen de cumplimiento progresivo de la pena y su cumplimiento en libertad (libertad condicional); y la Ley $\mathrm{N}^{0} 7.821$, que estableció el primer régimen más o menos amplio de remisión condicional de las penas privativas de libertad inferiores a un año, como medida contra las penas cortas de prisión.

\footnotetext{
${ }^{133}$ PEÑA, Federico, “Observaciones al nuevo Proyecto de Código penal”, Revista de Ciencias Penales, t. IV (1938), pp. 379-392 y 465-470.

134 BRÜCHER, Eduardo, "Anotaciones médico-legales al Proyecto de Código penal Silva-Labatut", Revista de Ciencias Penales, t. IV (1938), pp. 379-392 y 465-470.
} 
Polit. crim. Vol. 5, No 9 (Julio 2010), Art. 4, pp. 143-206.

[http://www.politicacriminal.cl/Vol_05/n_09/Vol5N9A4.pdf]

Y en cuanto a las adecuaciones en la determinación de los prohibido y lo permitido, numerosas leyes especiales comienzan a contener disposiciones para sancionar penalmente conductas dentro de áreas fuertemente reguladas de la economía, entre ellas, las relativas a prendas especiales, construcciones y urbanización, compraventa de muebles a plazo, arrendamiento de inmuebles, cheques, quiebras, aeronavegación, ferrocarriles, alcoholes, etc. ${ }^{135}$ También el control político de la época se aprecia en las leyes de Abusos de Publicidad (DL No 425 de 1925) y de Defensa Permanente de la Democracia ( ${ }^{o}$ 8.987, de 1948).

\subsection{El abandono del proyecto positivista en la (re)codificación penal: el incompleto proyecto "técnico" de 1946 y la Ley $\mathbf{N}^{0} 11.625$ sobre "estados antisociales"}

\subsubsection{El Proyecto de "reformas técnicas" de 1946}

Por Decreto $\mathrm{N}^{\mathrm{o}} 2.729$, de 15 de junio de 1945, "teniendo presente que el tiempo transcurrido desde la dictación del Código Penal aconseja estudiar su reforma", se creó una Comisión, integrada mayormente por Ministros de los Tribunales Superiores y Profesores Universitarios, y presidida por el entonces Ministro de Justicia, don Enrique Arriagada Saldías, "para que estudio y proponga al Gobierno las reformas urgentes que necesita el Código Penal, sin romper la estructura y armonía de sus actuales disposiciones". ${ }^{136}$

La sola transcripción del encargo conferido a la Comisión podría, en atención a lo expuesto en el apartado $\mathrm{N}^{0} 1$ de este trabajo, darnos una buena razón del por qué de su fracaso: una reforma puramente "técnica" de ciertas disposiciones del Código penal, que no pretendiera ser una fijación del texto punitivo para el futuro, con un propósito penológico determinado y de conformidad con los cambios sociales producidos hasta el momento, era y es innecesaria.

A ello debe agregarse el carácter incompleto del Proyecto, centrado en la Parte general del texto punitivo, donde, aparte de reformas "técnicas" o de carácter "dogmático" (algunas de ellas ya propuestas en los proyectos anteriores), ${ }^{137}$ no apunta a una reforma

\footnotetext{
${ }^{135}$ Véase detalladamente al estado de situación en 1960 de las diversas modificaciones del Código penal y las leyes especiales y complementarias, en NOVOA MONREAL, Eduardo, Curso de Derecho penal chileno, Parte general, t. I, $3^{\circ}$ ed. Texto original (1960) con notas, Santiago: 2005, 585 pp, pp. 105-107.

${ }^{136}$ El texto del Decreto de creación de esta Comisión y nombramiento de sus integrantes, se encuentra en Proyecto de Reforma del Código penal, Libro Primero, elaborado por la Comisión designada en el Decreto Supremo Núm. 2.729 de 15 de junio de 1945, del Ministerio de Justicia, Santiago de Chile: Dirección General de Prisiones, 1946, 158 pp., p. 3. Esta Comisión, de tan limitados propósitos, estaba conformada por el propio Sr. Ministro de Justicia, don Enrique Arriagada, quien la presidió; el Ministro de la Corte Suprema, don Gregorio Schepeler; los Ministros de las Cortes de Apelaciones de Santiago, don Luis Agüero y don Franklin Quezada; el ex Ministro, Sr. Bianchi; el Juez del 7º. Juzgado del Crimen de Santiago, don Luis Montero; el Presidente del Instituto de Ciencias Penales, don Luis Cousiño MacIver; el Profesor de Derecho penal de la Universidad de Chile, don Miguel Schweitzer; el Director General de Prisiones, don Julio Olavarría; y los abogados Srs. Abraham Drapkin y Eduardo Novoa Monreal, quien actuó como Secretario. Oficialmente, el Proyecto se reduce a una reforma de la Parte General del Código de 1874, publicado junto con las Actas del trabajo de la Comisión en el texto arriba citado.

137 Éstas son, principalmente, las siguientes: cambio de la expresión "voluntaria" por "dolosa" en la definición de delito del artículo primero; se suprime el delito frustrado y se vuelven a redactar las reglas del desistimiento (art. $8^{\circ}$ ); se "ordenan" las eximentes (art. 11), pasando a ser la primera la de la "fuerza física irresistible", agregando la "amenaza de un mal" como cuarta, y ampliando el estado de necesidad a a delitos contra las personas (art. $11 \mathrm{n}^{\circ} 8^{\circ}$ ); se elimina el "encubrimiento" como forma de participación
} 
MATUS, JEAN PIERRE. "La doctrina penal de la (fallida) recodificación chilena del Siglo XX y principios del XXI".

del sentido y propósito del sistema penal, sino que se enmarca dentro de la estructura y filosofía del Código vigente, manteniendo la división tripartita en crímenes, simples delitos y faltas, su estructura penológica y casi todas sus disposiciones, e incorporando a él, en lo sustancial, únicamente la ya vigente legislación que permitía la remisión condicional de las penas privativas de libertad inferiores a un año (arts. 83-86) y el cumplimiento progresivo de las condenas, mediante la libertad condicional (arts. 74-82). "Su mayor novedad", del Secretario de la Comisión, "está en un título completo destinado a asegurar la reparación del daño al ofendido por el delito, mediante medidas de eficacia práctica". ${ }^{138}$

De ahí que incluso Grisolía, quien proponía todavía en 1967 "utilizar el Proyecto de 1946", para "hacer, con urgencia, ciertas reformas parciales que son efectivamente necesarias", reconoce que este proyecto no contiene, en verdad, "ninguna innovación espectacular" y se mantiene "dentro del criterio clásico exclusivamente retribucionista", calificándolo como "un simple y aceptable $<<$ remozamiento $>>$ de la Parte General del actualmente vigente." $" 139$

Debido a este condicionamiento básico, a lo que se suma el hecho de no contar la Comisión entre sus integrantes con Diputados y Senadores en ejercicio, de nada pudo servir el apoyo político al Proyecto del entonces Ministro de Justicia, Sr. Arriagada, quien participó personalmente y presidió todas las Sesiones Plenarias de la Comisión y a casi todas las de su Subcomisión, encargada de "traer las sugestiones concretas relativas a las reformas que debe estudiarse del Libro Primero del Código Penal", ${ }^{140}$ llevadas a cabo entre el 28 de junio de 1945 y el 16 de enero de 1946; ni la intervención en ella del entonces Presidente del Instituto de Ciencias Penales, don Luis Cousiño Mac-Iver y del ya destacado penalista don Eduardo Novoa Monreal, como Secretario.

No obstante, el Proyecto se presentó a la Comisión de Legislación y Justicia del Senado, la cual "sólo esporádicamente" se preocupó de su estudio. ${ }^{141}$ Según Novoa,

"La Comisión de Reforma continuó sus trabajos con el Libro II, y avanzó en la elaboración de nuevos títulos relativos a delitos contra la seguridad exterior e interior del Estado y contra los derechos garantidos por la Constitución. El desánimo provocado por la indiferencia del Legislativo para sus anteriores esfuerzos, la dispersó a mediados de 1949."142

Aunque Novoa no se explica la "indiferencia" del Congreso con el Proyecto de reforma, ello ya parece meridianamente claro por lo antes dicho: el Proyecto, en realidad, no

(art. 15) y se agrega una forma de autoría mediata ("al que para la perpetración del delito se vale de la acción de otro a quine no afecta responsabilidad penal" (art. 16, $\mathrm{n}^{\circ} 3^{\circ}$ ); moral"; agregándose también una definición de "delito continuado" (art. 25).

${ }^{138}$ NOVOA MONREAL, Eduardo, Curso de Derecho penal chileno, Parte general, t. I, $3^{\circ}$ ed. Texto original (1960) con notas, Santiago: 2005, 585 pp., p.108.

${ }^{139}$ GRISOLÍA, "La reforma penal", cit. nota no 38 , pp. 320 y 329.

${ }^{140}$ Proyecto de reforma (1946), cit. nota $\mathrm{n}^{\circ} 136, \mathrm{p} .40$.

${ }^{141}$ COUSIÑO MAC IVER, Luis, Derecho penal chileno, $t$. I, Santiago: Ed. Jurídica de Chile, 1975, 960 pp., p. 77.

${ }^{142}$ NOVOA, Curso I, cit. nota $\mathrm{n}^{\circ} 138$, p. 108. El Título I del Libro II que elaborase esta Comisión, sobre "Delitos contra la Seguridad Exterior y Soberanía del Estado", apareció publicado posteriormente en la Revista de Ciencias Penales, t. X (1948), pp. 146-149, incluía, según la nota al pie que contiene "novedosos tipos delictivos que se configuran como consecuencia de la experiencia obtenida de la última guerra mundial", lo que, al revisarse las disposiciones en cuestión, no resulta del todo exacto. 
Polit. crim. Vol. 5, No 9 (Julio 2010), Art. 4, pp. 143-206.

[http://www.politicacriminal.cl/Vol_05/n_09/Vol5N9A4.pdf]

contenía ninguna proposición novedosa que obligase a su estudio y sin la cual nuestro sistema penal no pudiese seguir operando de conformidad a las valoraciones sociales de la época, o con la cual se esperase una importante mejoría en el cumplimiento de sus fines, aún dentro de esquema social reinante que, como ya hemos apuntado, no había variado sustancialmente del heredado desde el siglo XIX, a pesar del arreglo institucional que dio lugar al derrumbamiento de la República Oligárquica en 1925.

Tampoco debe olvidarse, para explicar el fracaso de este proyecto, que fue elaborado en el imprevisto último año del Gobierno del gobierno radical de Juan Antonio Ríos, bajo el impulso del Ministro de Justicia Arriagada Saldías, miembro del Partido Socialista Auténtico, quien dejó el cargo el 30 de enero de $1946,{ }^{143}$ tras asumir el Vicepresidente Duhalde, producto de la enfermedad de Ríos. A ello se sumó luego la muerte de Ríos y las vicisitudes electorales de ese año dejaron al Partido Socialista fuera del primer Gabinete de Gabriel González Videla, ad portas de la nueva división que condujo, en 1948, a la dictación de la Ley de Defensa Permanente de la Democracia, instaurándose una etapa que Mulián denomina de "dominación represiva" por parte de la alianza radical y conservadora, en pos de la mantención del status quo frente a lo que entonces se consideró la "amenaza" comunista. ${ }^{144}$

2.1.3. El "canto de cisne" del proyecto positivista en Chile: la Ley $\mathrm{N}^{\circ} 11.625$, de 4 de octubre de1954. Otras reformas de la legislación penal durante la segunda mitad del siglo XX

Ya hemos señalado que en el segundo cuarto del siglo XX, a pesar de no haber prosperado los proyectos positivistas vinculados a la llamada escuela moderna o de política criminal alemana de 1929 y 1938, parte de sus ideas habían tenido consagración legal, a través en la exclusión de los jóvenes del sistema punitivo, mediante de la Ley de Protección de Menores; la reducción de las penas cortas de prisión, mediante la Ley de Remisión Condicional de las penas privativas de libertad menores a un año; y de la instauración de un sistema progresivo de cumplimiento de penas, mediante el DL 321 de 1925, sobre Libertad Condicional.

No obstante, la idea de establecer medidas de seguridad para personas en "estado peligroso", tanto si habían o no cometido delitos, no tenía éxito todavía. Es más, según declaraba Schepeler en las Jornadas Nacionales de Ciencias Penales del año 1949,

"el proyecto de reforma del año 46 importa un retroceso con respecto a los anteriores, ya que se limita a someter al reincidente a la vigilancia de la autoridad (art. 28), medida insuficiente para curar el hábito del delito."

Schepeler defendía en ese año 1949 el Proyecto propuesto ya en 1941 por el Instituto de Ciencias Penales, ${ }^{146}$ pretendiendo con su adopción "contribuir a solucionar el problema

\footnotetext{
${ }^{143}$ RAMÓN, Armando de (Ed.), Biografias de chilenos, vol. I, Santiago: Ed. Universidad Católica de Chile, 1999, 335 pp., p. 105s.

${ }^{144}$ MULIÁN, Tomás, Fracturas. De Pedro Aguirre Cerda a Salvador Allende (1938-1973), Santiago de Chile: LOM, 2006, 274 pp. , pp. 126-131 y 143ss.

${ }^{145}$ SCHEPELER, Enrique, "Estados anti-sociales. Aspecto Jurídico", Revista de Ciencias Penales, t. XI (1949), pp. 53-61, p. 57. Véase también, en este mismo tomo de la Revista d Ciencias Penales, las otras aportaciones hechas, en defensa del Proyecto de 1941, en las mencionadas Jornadas Nacionales de Ciencias Penales de 1949, por Manuel BECA ("Estados antisociales. Aspecto Psiquiátrico", pp 62-67); Francisco FILIPENSKY ("Los Estados anti-sociales. Aspecto policial”, pp. 68-73); y María ASTICA ("La asistencia social en los estados antisociales", pp. 74-83).
} 
MATUS, JEAN PIERRE. "La doctrina penal de la (fallida) recodificación chilena del Siglo XX y principios del XXI".

de la represión y tratamiento adecuado de la vagancia y otros estados afines", frente al cual se denuncia la "insuficiencia y atraso" del Código vigente, para salir de lo cual sería preciso que:

“a) Debe aceptarse ampliamente en nuestro sistema penal la fórmula del estado peligroso, tanto delictual como predelictual, lo cual requiere una profunda reforma del Código Penal que nos rige;

"b) Debe establecerse como medio de lucha contra el sujeto peligroso la aplicación de medidas de seguridad, sin perjuicio de la pena, cuando la peligrosidad se manifiesta por la comisión del delito; $y$

“c) Las medidas de seguridad deben sr impuestas por la judicatura ordinaria, como un medio de evitar la arbitrariedad". ${ }^{147}$

Dicho proyecto contemplaba la descripción de los "estados antisociales" o "peligrosos" delictuales (reincidentes) y, sobre todo, predelictuales (vagos, mendigos, alcohólicos, toxicómanos, jugadores), y una serie de "medidas de seguridad" indefinidas (básicamente, internamientos en casas de salud, trabajo y colonias agrícolas), con la sola advertencia de que ellas no podrían empezar a aplicarse sino hasta el momento en que efectivamente existiesen los establecimientos de trabajo, salud y agrícolas que se establecen para el internamiento de los sujetos peligrosos, pues de otro modo, "dicho proyecto, de llegar a ser ley, nada cambiaría, porque es previo crear los institutos adecuados para que pueda funcionar la ley". ${ }^{148}$

\section{Según relata Novoa,}

"El interés prestado a esta materia movió a los Poderes Públicos a ocuparse de ella y es así como el Ejecutivo envió al Congreso un proyecto a base del preparado por el Instituto [de Ciencias Penales]. Dicho proyecto, después de un amplio debate parlamentario, pasó a ser, con algunas modificaciones, la Ley $\mathrm{N}^{\mathrm{o}} 11.625$.,149

Sin embargo, no debe perderse de vista que esta Ley no contemplaba solamente la realización de un proyecto "académico" de instalar en Chile las "medidas de seguridad" 150 para "peligrosos"; ${ }^{151}$ sino también modificaciones radicales al Código

\footnotetext{
${ }^{146}$ En Revista de Ciencias Penales, t. V (1941), pp. 60-68. Los antecedentes del Proyecto, entre ellos, la Ley española de vagos y maleantes de 1933, pueden verse en RIVACOBA, Evolución, cit. nota n 3 , p. $109 \mathrm{~s}$.

${ }^{147}$ SCHEPELER, "Estados anti-sociales", cit. nota no 145 , pp. 56, 58 y 60.

${ }^{148}$ SCHEPELER, "Estados anti-sociales", cit. nota no 145, pp. 60.

149 NOVOA MONREAL, Eduardo, Curso de Derecho penal chileno, Parte general, t. II, $3^{\circ}$ ed. Texto original (1960) con notas, Santiago: 2005, 475 pp, p. 376.

${ }^{150}$ Éstas eran, según el art. $3^{\circ}$, las siguientes:“ $1^{\circ}$ ) Internación en casa de trabajo o colonia agrícola por tiempo indeterminado que no podrá exceder de cinco años; $2^{\circ}$ ) Internación curativa en establecimientos adecuados por tiempo absolutamente indeterminado; $3^{\circ}$ ) Obligación de declarar domicilio o de residir en un lugar determinado por tiempo que no podrá exceder de cinco años; $4^{\circ}$ ) Prohibición de residir en lugar o región determinados por un plazo no superior a cinco años; $5^{\circ}$ ) Sujeción a la vigilancia del Patronato de Reos que corresponda por un tiempo que no podrá exceder de cinco años; $6^{\circ}$ ) Caución de conducta por un tiempo que no podrá exceder de cinco años; $7^{\circ}$ ) Multa de quinientos a cincuenta mil pesos, y $8^{\circ}$ ) Incautación y pérdida de dinero o efectos."

${ }^{151} \mathrm{Su}$ artículo $1^{\circ}$ califica como tales a vagos ("los que no teniendo hogar fijo o viviendo en el de otra persona por mera tolerancia o complacencia, carezcan de medios lícitos de subsistencia y sin estar impedidos para el trabajo, no ejerzan habitualmente profesión u oficio"); mendigos ("los que sin la competente licencia, pidan habitualmente limosna en lugares públicos o de acceso al público"); "ebrios consuetudinarios"; "toxicómanos"; a los que "por cualquier medio induzcan, favorezcan, faciliten o exploten las prácticas homosexuales"; a "los que oculten su verdadero nombre, disimulen su personalidad
} 
penal, en materia de hurtos y robos, particularmente contra el llamado "cogoteo" o robo violento, con el "propósito de reprimir estos hechos con la mayor severidad": 152 se amplía la legítima defensa privilegiada a la evitación de tales delitos (art. 40); se aumentan las penas y redefine el llamado robo calificado del art. 433, ampliándose su ámbito de aplicación (art. 43); se crea el delito de "robo por sorpresa" del artículo 436 (art. 45); se asimila la pena de la tentativa a la de la consumación en los delitos de robo en lugar habitado y robo violento y se establece una agravante especial de porte de armas (art. 51); se castiga como cómplice al receptador (art. 52); y se agregan las circunstancias agravantes específicas del actual artículo 456 bis del Código penal (art. 53). Quizás la única temperación de esta ley, es la reforma al artículo 70 del Código penal, que permite el pago de las multas impuestas en parcialidades (art. 42). En los aspectos procesales, las principales innovaciones son la reducción del tiempo del sumario y, sobre todo, la facultad que se concede al tribunal de apreciar la prueba en conciencia, sin someterse a las entonces vigentes reglas de valoración de prueba (arts. 54 y 59$)$.

Esta preocupación por el "combate" a los delitos de hurto y robo, particularmente el violento, era coincidente con los programas políticos de la casi totalidad de los partidos políticos en el último gobierno radical de Gabriel González Videla (1946-1952), incluyendo los de izquierda; y, por cierto, también los de su sucesor, el general Carlos Ibáñez del Campo (1952-1958). ${ }^{153}$

En cambio, la imposición de costosas medidas de seguridad en nuevos establecimientos curativos, de trabajo y colonias agrícolas que debían crearse y financiarse, no contó en ningún momento con el respaldo gubernamental real, quedando las medidas de seguridad puramente en letra muerta, aún cuando la ley permitía que, en tanto esos establecimientos se crearan, el Presidente designara como tales, por Decreto, "los establecimientos adecuados para la detención y la intervención de los antisociales, aun cuando fueren mantenidos por instituciones privadas que los acepten" (art. 65). Ese Decreto nunca se dictó, a pesar de la sucesión posterior de Gobiernos de muy distinto signo; y, de conformidad a con lo dispuesto en el artículo 69 de la Ley, todo su Título I,

o falseen su domicilio"; a "los que habiendo sido condenados por delitos contra el patrimonio, sean sorprendidos con especies cuyo modo legítimo de adquisición no expliquen satisfactoriamente, o con instrumentos, llaves, mecanismos o artificios habitualmente empleados para la comisión de delitos de robo"; y a los que comercien con "especies de dudosa procedencia". Sólo excepcionalmente se establecía un "estado antisocial" como consecuencia directa de la comisión de delitos, como los de los condenados tres veces por ebriedad y el de "los que hayan reincidido o reiterado en toda clase de hechos punibles en los que sea de presumir la habitualidad criminal."

${ }^{152}$ NOVOA, Curso I, cit. nota ${ }^{\circ} 138$, p. 105.

153 Esta coincidencia en la torno a una "postura moralizadora y represiva en relación a los grupos populares" está bien documentado por CANDINA Polomer, Azun, "Seguridad Ciudadana y Sociedad en Chile Contemporáneo. Los delincuentes, las políticas y los sentidos de una sociedad”, Revista de Estudios Históricos, Vol. 2 , $\mathrm{N}^{\mathrm{o}} 1$ (2005),

http://www.estudioshistoricos.uchile.cl/CDA/est_hist_simple/0,1474,SCID\%253D15047\%2526ISID \%25 3D540\%2526PRT\%253D15044,00.html [visitado por última vez el 15.03.2010]. Allí pueden verse, entre otras, las apreciaciones de Salvador Allende sobre el particular y el programa "represivo" en lo penal del candidato socialista en 1946, Adolfo Ibáñez. Sin embargo, que esta coincidente preocupación llevase también a un acuerdo real por la implantación efectiva de "medidas de seguridad" contra ciertos grupos sociales, como parece desprenderse del resto de las afirmaciones contenidas en el texto citado, es más que discutible por la sola constatación histórica de que ello estuvo a la mano de cualquier Presidente de los distintos gobiernos que se sucedieron al segundo de Ibáñez: Alessandri Rodríguez, Frei Montalva, Salvador Allende, Augusto Pinochet y Patricio Aylwin esquivaron sin más la cuestión, simplemente no dictando el Decreto a que hacía referencia el artículo 65 de la Ley $N^{\circ} 11.625$, 
MATUS, JEAN PIERRE. "La doctrina penal de la (fallida) recodificación chilena del Siglo XX y principios del XXI".

que establecía los estados antisociales y las medidas de seguridad, nunca entró en vigor, hasta su derogación formal por el artículo $1^{\circ}$ de la Ley Nº 19.313, de 1.994.

Por otra parte, en las doctrina penal, la favorable acogida inicial de las "medidas de seguridad" predelictuales que establecía esta ley ${ }^{154}$ fue rápidamente perdiendo apoyo, tanto en Chile como en el extranjero. ${ }^{155}$

En consecuencia, este Título I de la Ley $\mathrm{N}^{\circ} 11.625$ puede ser visto como el "canto de cisne" del positivismo en Chile, una suerte de victoria a lo Pirro de sus defensores, pues nunca entró a regir, pero sí lo hicieron las medidas represivas de sus Títulos II y III.

No obstante, como hemos demostrado en un texto anterior, las ideas positivistas han mantenido su influencia entre nosotros, aún a pesar de que ya no se estila su defensa en los términos que lo hacían Fontecilla y Del Río ni tampoco existen entre nosotros defensores de las medidas de seguridad predelictuales como las de la Ley $\mathrm{N}^{\mathrm{o}} 11.625{ }^{156}$ lo cierto es que sobre todo a partir de la enorme extensión dada a las medidas alternativas al cumplimiento de las penas privativas de libertad por la Ley $\mathrm{N}^{\circ} 18.216 \mathrm{y}$ otros sustitutos penales contenidos en el nuevo Código Procesal Penal y en la Ley sobre Responsabilidad Penal de los Adolescentes. ${ }^{157}$

\subsection{El abandono de la pretensión (re)codificadora por el Estado y por la doctrina penal chilena en la segunda mitad del Siglo XX. El salto hacia el vacío del proyecto del Código penal tipo para Latinoamérica}

\subsubsection{El contexto en las décadas de 1950 a 1970}

Inconcluso y sin éxito legislativo el Proyecto de 1946, desde ese momento, no se intentó oficialmente por el Estado de Chile ningún proceso de (re)codificación del Código penal durante el resto del siglo. ${ }^{158}$

\footnotetext{
${ }^{154}$ Véase, por ejemplo, NOVOA, Curso I, cit. nota n ${ }^{\circ} 138$, p. 105, quien señalaba en 1960 que "el alcance de esta ley es trascendental, puesto que organiza la prevención del delito e inyecta en nuestra vetusta legislación penal preceptos que se ajustan a adelantados principios científicos". Por su parte, desde el extranjero, JIMÉNEZ DE ASÚA, Tratado I, cit. nota n 28, p. 1176, calificaba en 1963 entre las "leyes modernas contra el estado peligroso".

${ }^{155}$ Así, ya en 1967, GRISOLÍA, "La reforma penal", cit. nota $n^{\circ} 38$, p. 306, nota 53, calificaba la no entrada en vigor del Título I de la Ley $\mathrm{N}^{\circ} 11.625$ como una "feliz circunstancia" ante el carácter "desafortunado" que le atribuye; y en 1974, Marino Barbero, habla directamente del "recriminable sistema de la peligrosidad predelictual" que dicha ley contemplaba (BARBERO, Marino, "La fundamentación doctrinal y la orientación político-criminal del Código penal chileno en el panorama actual del Derecho penal", en RIVACOBA, Actas, cit. nota $\mathrm{n}^{\circ} 74$, pp. 35-41, p.40. No obstante, todavía en 1991, RIVACOBA, Evolución, cit. nota n ${ }^{\mathrm{o}} 3$, p. 112, mantiene un juicio más o menos favorable, tanto al hecho de deferir su aplicación mientras no se cuente con los establecimientos adecuados, como a su contenido mismo, respecto del cual señala: "hay que reconocer que tiende a lograr su cometido y finalidad sin avasallar la dignidad humana ni la libertad personal, si bien la perspectiva actual en la materia ofrece criterios para proteger con más eficacia al individuo frente a las limitaciones y privaciones a que sin duda queda sometido por la aplicación de dichas medidas."

${ }^{156}$ Véase, por todos, CURY, Enrique, Derecho penal, parte general, $7^{a}$ ed. Ampliada, Santiago: Ed. Universidad Católica de Chile, 2005, 812 pp., p. 776.

${ }^{157}$ MATUS, "El positivismo", cit. nota al pie no 88, p. 197.

${ }^{158}$ Es cierto que el denominado "Foro Penal" venía reuniéndose con los auspicios del Ministerio de Justicia desde agosto de 1.999, pero no fue sino hasta por Decreto del Ministerio de Justicia de 12 de junio de 2003 que esta Comisión se formalizó y recibió el encargo de redactar un Anteproyecto de Nuevo Código Penal.
} 
Polit. crim. Vol. 5, No 9 (Julio 2010), Art. 4, pp. 143-206.

[http://www.politicacriminal.cl/Vol_05/n_09/Vol5N9A4.pdf]

Candina intenta la siguiente respuesta a la pregunta acerca por qué después de los años 1950, para la política nacional el "problema penal" dejó de ser tal y, en consecuencia, careció de urgencia o necesidad una (re)codificación:

\begin{abstract}
“¿Qué ocurrió después de los años cincuenta? A nivel exploratorio y en una hipótesis que debe investigarse con mayor acuciosidad y profundidad, entre los años sesenta y los ochenta, la delincuencia "pura" parece haber pasado a un remoto segundo plano. Hablar de "seguridad" se transformó, para los sectores derechistas y luego para los partidarios de la Dictadura, en hablar de "seguridad interior del Estado", es decir, de la amenaza y el necesario control a los elementos subversivos. Asimismo, hablar de "seguridad" para los sectores de izquierda y centro - los opositores a ella- se refirió a la represión contra los sectores populares y de izquierda. La delincuencia, aparentemente, no fue para los chilenos una de sus grandes preocupaciones. Pareció haber en Chile, durante muy largo tiempo, situaciones y personas mucho peores y más peligrosas que los asaltantes, los borrachos o los niños vagos que robaban en las calles." 159
\end{abstract}

Sea esta hipótesis correcta o no, lo cierto es que la sociedad de la segunda mitad de siglo empezó a sufrir el intento de realizar grandes transformaciones animadas tanto por el espíritu reformista, revolucionario como por el contra revolucionario, que dejaban poco espacio para la discusión de asuntos como la reforma a un Código penal, si el país estaba preocupado por los cambios estructurales que suponían una reforma agraria, la distribución más equitativa del ingreso y el mejoramiento de las condiciones de vida de la población, particularmente, en cuestiones relativas a la educación, la salud y la vivienda, todo ello dentro del juego global de la Guerra Fría y las intervenciones de ambos bandos en el financiamiento y defensa de los intereses de quienes entendían sus aliados. $^{160}$

\title{
2.3.2. Pax dogmática y Código Penal Tipo para Latinoamérica
}

Curiosamente, mientras la sociedad transitaba hacia este ambiente confrontacional, después de los años 1940, los penalistas chilenos se refugiaban en lo que Rivacoba calificó de pax dogmática, ${ }^{161}$ a través de la "acción decisiva de juristas como M. Schweitzer, L. Cousiño, G. Labatut. E. Novoa, A. Bunster”, quienes, según Grisolía,

“apartándose de todo bizantinismo de Escuelas, conforme a las más destacadas corrientes del pensamiento jurídico penal que conocen y saben manejar, emprenden la tarea de elaborar científicamente, con estricto rigor dogmático, nuestra ley punitiva vigente."162

En este ambiente se formaron los "espíritus jóvenes" que, según el mentor de buena parte de ellos, Álvaro Bunster, "anuncia[ban] una nueva época en los estudios jurídicos chilenos ... que tiende dignamente a huir del comentario exegético sin visión", 163

${ }^{159}$ CANDINA, Seguridad ciudadana, cit. nota $\mathrm{n}^{\mathrm{o}} 153$.

${ }^{160}$ CORREA/FIGUEROA/JOCELYN-HOLT/ROLLE/VICUÑA, Historia, cit. nota n ${ }^{\circ}$ 94, pp. 210-276.

${ }^{161}$ RIVACOBA, "Estudio preliminar", cit. nota n ${ }^{\circ} 66$, p. $x l$.

162 GRISOLÍA, "La reforma penal", cit. nota $\mathrm{n}^{\mathrm{o}}$ 38, p. 310.

${ }^{163}$ BUNSTER, Álvaro, "Prólogo", En POLITOFF, Sergio, El delito de apropiación indebida, Santiago de Chile: Ed. Nascimento, 1957, 241 pp. , pp. 5-7, p. 5. En el excelente trabajo de BERNALES, Emmanuel; MATUS, Jean Pierre (Prof. Guía), Álvaro Bunster Briceño: vida, obra e influencia en el Derecho penal actual, Memoria de Grado U. de Talca, Talca: 2009, 65pp., más anexos, aparece claramente la influencia de Bunster en la motivación de sus "discípulos para hacer del derecho penal la rama jurídica de 
MATUS, JEAN PIERRE. "La doctrina penal de la (fallida) recodificación chilena del Siglo XX y principios del XXI".

recogiendo la nueva forma dogmática en sus primeros trabajos monográficos: Enrique Cury, ${ }^{164}$ Alfredo Etcheberry ${ }^{165}$, Luis Ortiz ${ }^{166}$, Sergio Politoff ${ }^{167}$, Armando Uribe ${ }^{168}$ y Jaime Vivanco ${ }^{169}$, Antonio Bascuñán V., ${ }^{170}$ Jorge Mera $^{171}$ y Mario Garrido, ${ }^{172}$ entre otros.

Estos profesores y estudiosos se congregaban simultáneamente en el Seminario de Derecho Penal de la Universidad de Chile, dirigido en los años 1960 por Álvaro Bunster; y en el Instituto de Ciencias Penales, dirigido por Eduardo Novoa Monreal. ${ }^{173}$

Allí concibió Eduardo Novoa Monreal la idea de que:

"el Instituto se haga cargo de propiciar el estudio de un proyecto de Código Penal Tipo para Latinoamérica. Este proyecto sería elaborado en diversas etapas y con el concurso de todos los penalistas más calificados del continente, para lo cual se celebrarían reuniones o congresos periódicos con este fin. Chile tomaría la iniciativa y organizaría la primera reunión internacional de este tipo, invitando a Santiago para el próximo año a un grupo de destacados especialistas latinoamericanos." $" 174$

El objetivo final de estos trabajos sería la elaboración de un:

"modelo estructural básico de la legislación penal iberoamericana, [que] contenga un conjunto de normas comunes [las cuales] serían adoptadas por los países iberoamericanos, en virtud de acuerdo conjunto o adhesión sucesiva de sus gobiernos". ${ }^{175}$

La sola transcripción de "la idea" y "objetivo" del Proyecto, que, según Rivacoba, resultaba "conformista con la situación existente y sólo renovadora en lo externo y

preferencia" (p. 60), aunque, posteriormente, "no juega un rol fundamental en el derecho penal como referente bibliográfico" (p. 64).

${ }^{164}$ CURY U., Enrique, El delito continuado, Memoria de Prueba U. de Chile, Santiago de Chile: Ed. Jurídica, 1962, 119 pp.

${ }_{165}$ ETCHEBERRY O., Alfredo, El concurso aparente de de leyes penales, Santiago de Chile: Ed. Jurídica de Chile, 1955, 118 pp.

166 ORTIZ Q., Luis, Teoría de las hipótesis preterintencionales, Santiago de Chile: Ed. Jurídica, 1959, $107 \mathrm{pp}$.

${ }^{167}$ POLITOFF, Apropiación indebida, cit. nota $\mathrm{n}^{\circ}$ 167. Una década después, esta nueva dogmática aparece en una obra general: POLITOFF, Sergio; BUSTOS, Juan y GRISOLÍA, Francisco, Derecho penal chileno, parte especial, Santiago de Chile: Ed. Jurídica, 1971, 405 pp.

${ }^{168}$ URIBE A., Armando, De los delitos calificados por el resultado, Santiago de Chile: Ed. Jurídica, $1957,75 \mathrm{pp}$.

${ }^{169}$ VIVANCO S., Jaime, El delito de robo con homicidio. Ensayo a la luz de la doctrina del delito-tipo, Santiago de Chile: Ed. Jurídica, 1957, 102 pp.

${ }^{170}$ BASCUÑ́́N V., Antonio, El delito de abusos deshonestos, Santiago de Chile: Ed. Jurídica, 1961, 159 pp.

${ }^{1}$ MERA F., Jorge, El delito de entrega fraudulenta. Santiago de Chile: Ed. Encina, 1971, 269 pp.

172 GARRIDO M., Mario, Los delitos contra el honor, Santiago de Chile: Carlos Gibbs Ed., 1963, 381 pp.

173 Sobre la enorme influencia e importancia en la vida nacional de este autor, véase GUERRA G., Beatriz; MATUS, Jean Pierre (Prof. Guía), Eduardo Novoa Monreal: vida, obra e influencia dogmática en el Derecho penal actual, Memoria de Prueba U. Talca: Talca, 2005, 84 pp., más anexos.

174 INSTITUTO DE CIENCIAS PENALES, Proyecto de Código penal tipo para Iberoamérica. Antecedentes, plan de trabajo, documentos preparatorios, Santiago de Chile: 1963, 21 pp., p. 1.

${ }^{175}$ Íd., p. 8. 
Polit. crim. Vol. 5, No 9 (Julio 2010), Art. 4, pp. 143-206.

[http://www.politicacriminal.cl/Vol_05/n_09/Vol5N9A4.pdf]

superficial, nada original y de evidente sentido elitista"; ${ }^{176}$ nos ahorra mayores explicaciones acerca de su fracaso en cuanto a servir, en Chile, de modelo para una (re)codificación penal: se trataba de una iniciativa privada, ajena a la vida política del país, de carácter "técnico", entregada únicamente a un conjunto de académicos y sin plazos fijos para su término. ${ }^{177}$

Además, como hemos escrito anteriormente,

"La manera como se organizaron los trabajos podía difícilmente conducir a un resultado satisfactorio: la proposición de soluciones técnicas complicadas a reuniones heterogéneas, en las que se procedía con los debates y votaciones propios de las asambleas democráticas y en las que se consideraban los matices "sofisticados" de las doctrinas prevalecientes en Alemania o Italia, con escasa preocupación por la realidad social de los respectivos países, condujo - a pesar de las buenas intenciones - a un exuberante y escasamente utilizable despliegue de erudición." ${ }^{\prime 178}$

No obstante, se debe decir que si no en Chile, al menos la Parte General del Proyecto influyó significativamente en las reformas penales de Costa Rica, de 1970; Guatemala y El Salvador, de 1973; Colombia, de 1980; y del Estado de Nuevo León, México, de 198, lo que Rivacoba en 1987 atribuía al "entusiasmo" que esta idea aristocratizante y "técnica" había provocado, afirmando que:

“en un mundo que apenas hacía veinte años que se había incorporado al pensar y al quehacer dogmático en Derecho penal, en que quedaban y aún quedan, muchos profesores que no han descubierto otro horizonte que el de una corta exégesis, y que ni siquiera en sus cabezas más altas y mejor informadas había recibido todavía el eco de las corrientes del momento en Europa [...] y, menos, naturalmente, se

\footnotetext{
${ }^{176}$ RIVACOBA, Manuel, "Pensamiento penal y criminológico del Código penal tipo para Iberoamérica", Doctrina penal, Año 10, ns 37 a 40 (1987), pp.713-734, p. 719. La visión “optimista” y que no se hacía cargo de estos cuestionamientos, sino, al contrario, manifestaba su acuerdo "en cuanto a que la unificación de las leyes penales de las naciones hispanoamericanas es posible en la práctica y deseable para una más eficaz tutela de los valores jurídicos fundamentales en que se cimenta la convivencia entre esos pueblos; a que la diversidad de sistemas legislativos imperantes no es un obstáculo insalvable, puesto que el estado de la ciencia penal en su momento actual permite llegar a fórmulas técnico-legales concretas", puede verse en GRISOLÍA, Francisco, El Código penal tipo para Hispanoamérica. Proceso formativo y estudio crítico, Tesis Doctoral, Madrid: U. Complutense, 1967, 151 pp. tipografiadas más anexos, p. 110.

${ }^{177}$ GRISOLÍA, "La reforma penal", cit. nota no 38, p. 328, nota al pie 113, escribía en 1967, cuando ya se había realizado tres Reuniones Plenarias (Santiago, 1963; México, 1965; y Lima, 1967), y se habían elaborado y aprobado textos que representaban "los dos tercios de la Parte general" (sobre ley penal, el hecho punible, las causas de justificación, la imputabilidad, la culpabilidad, autores y partícipes, tentativa, reincidencia, habitualidad y profesionalidad, y penas y medidas de seguridad), que "se han calculado unos diez años a contar de su iniciación" (1963) para su término. La verdad es que el proyecto no avanzó más allá de una Parte General y algunos títulos de la Parte Especial. El desgaste del paso del tiempo y, a partir de 1973, las circunstancias políticas de Chile, donde radicaba la Secretaría Ejecutiva del Proyecto, lo hicieron languidecer al punto de quedar abandonado tras la XII Reunión Plenaria, celebrada en Buenos Aires, en 1979. La Parte General y los materiales que le dieron origen fue editada en dos Tomos y tres Volúmenes por la Editorial Jurídica de Chile (Santiago de Chile, 1973). Los textos aprobados de la Parte Especial hasta 1975 (delitos contra las personas, contra la propiedad, contra el honor contra el orden económico y contra la libertad), se encuentran en VARIA, "Estado actual del proyecto de Código penal tipo para Latinoamérica", Revista de Ciencias Penales, t. XXXIV (1975), pp. 143-157 Completo, con lo aprobado en Buenos Aires, en LEVENE/ZAFFARONI, Los códigos penales latinoamericanos, $t$. IV, Buenos Aires: La Ley, 1980, pp. 509-515.

${ }^{178}$ POLITOFF/MATUS/RAMÍREZ, Lecciones $P G$, cit. nota ${ }^{\circ} 16$, p. 44.
} 
MATUS, JEAN PIERRE. "La doctrina penal de la (fallida) recodificación chilena del Siglo XX y principios del XXI".

habían abierto al cuestionamiento y replanteo político criminal, en serio y a fondo, de los ordenamientos vigentes, la idea de unificar las legislaciones, según un patrón de depurada perfección técnica había de deslumbrar, expandirse y arraigar con facilidad y de proyectarse sin tardanza en las inquietudes y tareas legislativas." ${ }^{179}$

2.3.3. El contexto, diez años después del inicio de los trabajos del Código penal Tipo para Iberoamérica: Dictadura Militar (1973-1989) y posterior retorno a la democracia en Chile

Diez años después de iniciados los trabajos del Código penal tipo, la polarización política y social, así como el desgaste institucional consiguiente, condujeron al Golpe y consecuente Dictadura Militar de 1973 a 1989.

Luego, la labor de "reconstrucción nacional" emprendida por la Dictadura, con sus importantes y trascendentes reformas institucionales y económica, incluyendo no sólo la dictación de un Constitución y sus leyes complementarias, sino también un modelo neoliberal de la sociedad, transformaciones que en su mayoría rigen hasta hoy en día, tampoco parece haber dejado algún un espacio para discutir el "problema penal". En todo caso, en los hechos, el terrorismo de Estado desatado desde la Dictadura mitigaba bastante dicho "problema", por la constante presencia militar en las calles, el toque de queda de los primeros años, el propio aparato represivo secreto (DINA y CNI), y los estados de excepción constitucional más o menos permanentes.

Por su parte, el primer gobierno desde el retorno a la Democracia estuvo preocupado por el restablecimiento de las libertades públicas restringidas por la Dictadura y, en la medida de lo posible, de las formas democráticas en la vida social, consensuadas con la oposición y dentro de un marco de limitaciones impuestas real o imaginariamente por el todavía vigente poder militar, representado por quien permanecería como su Comandante en Jefe, Augusto Pinochet. ${ }^{180}$

Sólo durante el Gobierno de Eduardo Frei Ruiz-Tagle (1994-2000) la discusión en torno a los asuntos penales volvió al cauce de la "delincuencia común" y el "problema penal" resurgió con fuerza en la discusión pública. ${ }^{181}$

Sin embargo, la primera respuesta ensayada al respecto no tuvo que ver con el derecho penal, sino con el proceso penal: una alianza de intereses del Gobierno (por un mayor respeto a las garantías individuales) y de la oposición (por hacer más efectiva la "persecución penal"), creo el clima necesario para hacer posible la Reforma Procesal

\footnotetext{
${ }^{179}$ RIVACOBA, “Código penal tipo”, cit. nota no 176, p. 720. Es más. El fracaso de este Proyecto no ha sido óbice para que en un nuevo intento de "unidad iberoamericana", se haya dado comienzo el año 1994 a los trabajos de una "Comisión Redactora del nuevo Código penal tipo Latinoamericano", que han dado lugar a varias reuniones en diversos países latinoamericanos. El sólo hecho de que dicha Comisión tenga un "Secretario perpetuo" y otras particularidades de la misma (no hay representantes del Cono Sur y los españoles parecen reducirse a los de las Islas Canarias), le auguran un no muy diferente destino que a su antecesora (véase al respecto, JAÉN VALLEJO, Manuel, "Informe sobre los últimos trabajos de la Comisión Redactora del Nuevo Código Penal Tipo Iberoamericano", en http://www.unifr.ch/ddp1/derechopenal/articulos/a_20080526_18.pdf [visitado por última vez el 30.03.2010].

${ }^{180}$ Para los datos históricos de los tres párrafos anteriores, véase CORREA/FIGUEROA/JOCELYNHOLT/ROLLE/VICUÑA, Historia, cit. nota n ${ }^{\circ}$ 94, pp. 279-351.

${ }^{181}$ CANDINA, Seguridad ciudadana, cit. nota $\mathrm{n}^{\circ} 153$.
} 
Polit. crim. Vol. 5, No 9 (Julio 2010), Art. 4, pp. 143-206.

[http://www.politicacriminal.cl/Vol_05/n_09/Vol5N9A4.pdf]

Penal, hoy traducida en un razonable sistema oral y contradictorio de enjuiciamiento criminal. ${ }^{182}$

\section{El Anteproyecto de Código penal para la Nación de 2005}

\subsection{Conformación inicial y procedimientos de trabajo}

\subsubsection{Génesis del Foro Penal}

El 2 de agosto de 1999, un año antes del término del segundo Gobierno democrático posterior a la Dictadura de 1973-1989, la entonces Ministra de Justicia, Sra. Soledad Alvear, convocó a una reunión de penalistas chilenos, profesores universitarios y abogados, para inaugurar el trabajo del "Foro Penal", una instancia de "diálogo" "para abordar ordenadamente los diversos elementos que integran nuestra regulación sustantiva, de modo tal de obtener bases mínimas y comunes," para abordar una posterior reforma tanto de la legislación penal sustantiva como del proceso de ejecución de la pena, objetivo enmarcado dentro del propósito mayor de una reforma integral al Sistema de Justicia Penal, que se había iniciado con la discusión del entonces Proyecto de Nuevo Código Procesal Penal. ${ }^{183}$

Lamentablemente, el Foro así convocado no se reunió más que esa vez, atendidas las urgencias electorales que se avecinaban, no dejando otro producto que la citada intervención de Antonio Bascuñán R., sobre las condiciones para el éxito de una eventual (re)codificación. ${ }^{184}$,

Electo el nuevo gobierno del Presidente Ricardo Lagos Escobar, por iniciativa del entonces Director Jurídico del Ministerio de Justicia, Sr. Francisco Maldonado Fuentes, se reactivaron en 2001 las reuniones del "Foro Penal", siguiendo el modelo informal de "centro de encuentro y discusión", ${ }^{185}$ hasta que a principios de 2003, el recientemente nombrado nuevo Ministro de Justicia, Sr. Luis Bates, aceptó la propuesta del Sr. Maldonado y de un grupo importantes de miembros del Foro, en orden a transformar estos "encuentros" en un trabajo sistemático de redacción de un Anteproyecto de Código penal que se pudiese presentar ante el Gobierno y, luego de su revisión por éste, ante el Congreso Nacional.

Así, la "Comisión de Estudio Para la Elaboración de un Anteproyecto de Código Penal o Comisión Foro Penal", fue formalmente creada por Decreto $\mathrm{N}^{\mathrm{o}} 443$ de 12 de junio de 2003, con la "exclusiva tarea" de presentar un "Anteproyecto de Código Penal para la

\footnotetext{
${ }^{182}$ Ver, Supra, nota $\mathrm{n}^{\circ} 77$, letra a), y $\mathrm{n}^{\circ}$ 81. Sea o no verdad que la reforma procesal penal es una condición previa para la (re)codificación penal, como lo proponía en 1967 GRISOLÍA, "La reforma penal", cit. nota $\mathrm{n}^{\mathbf{0}} 38$, p. 329 s., lo cierto es que ya se producido en Chile y la discusión al respecto resultaría, en este momento, algo sobrepasada por los hechos.

183 ALVEAR, Soledad, Reforma penal: un aporte a la consolidación de la convivencia social, Intervención de la Ministra de Justicia al inaugurar el trabajo del Foro Penal, Santiago, documento inédito, 2 de agosto de 1999.

${ }^{184}$ BASCUÑÁN R., Antonio, Observaciones, cit. nota $\mathrm{n}^{\mathrm{o}} 77$.

${ }^{185}$ ETCHEBERRY O., Alfredo, "Reflexiones sobre Política Criminal," Polit. crim. No 7 (2009), D2-7, pp. 1-16, p. 3 .
} 
MATUS, JEAN PIERRE. "La doctrina penal de la (fallida) recodificación chilena del Siglo XX y principios del XXI".

nación", cometido que se cumplió recién en diciembre de 2005, apenas unos meses antes del término de la administración de Ricardo Lagos. ${ }^{186}$

La Comisión estuvo formada por un Consejo Directivo, una Secretaría Técnica y la Sala del Foro Penal propiamente tal.

El Consejo Directivo estuvo nominalmente compuesto por un grupo selecto de aquellos “jóvenes espíritus" de la generación de $1960,{ }^{187}$ todos ya convertidos en experimentados profesores de las más importantes universidades del país (Universidad de Chile o la P. Universidad Católica) y, al mismo tiempo, Diputado, Ministros de Corte Suprema, o influyentes abogados de la plaza, autores o coautores en su mayoría de los textos de estudio universitario al uso a principios del siglo XXI: Juan Bustos R. (Diputado), ${ }^{188}$ Enrique Cury U. (Ministro Corte Suprema), ${ }^{189}$ Alfredo Etcheberry O. (Abogado), ${ }^{190}$ Mario Garrido Montt (Ministro Corte Suprema), ${ }^{191}$ Luis Ortiz Q. (Abogado), ${ }^{192}$ Sergio Politoff L. (Profesor universitario), ${ }^{193}$ y Sergio Yáñez P. (Profesor universitario y entonces, Presidente del Instituto de Ciencias Penales). ${ }^{194}$

Como "Presidente del Consejo Directivo" y "Coordinador del Foro Penal", se designó a Alfredo Etcheberry O., quien a principios del año 2004 renunció al encargo y dejó de asistir a las sesiones, por las razones que se expondrán más adelante. Le sucedió Enrique Cury, quien continuó en el cargo, hasta el término de las labores del Foro, el 8 de diciembre de 2005.

La Secretaría Técnica, fue nombrada por Res. Exenta N ${ }^{\circ} 1785$ de 17 de Junio de 2003, y estaba formada, por los entonces jóvenes profesores Héctor Hernández B. y Jean Pierre Matus, y los funcionarios del Ministerio Srs. Francisco Maldonado F., Fernando Londoño L. y, el último año, la Srta. Nelly Salvo. A los dos primeros les correspondía la labor de quienes tenían por misión preparar los Materiales de Discusión y las Propuestas de Articulado que se debatirían en el Foro; estando encargados los funcionarios del Ministerio de los procesos de organización y registro. Los redactores de los Materiales de Discusión y Propuestas de Articulado estudiaron en la misma época en la P. Universidad Católica de Chile (1986-1991) y fueron alumnos en Derecho penal de Luis Ortiz Q.; ambos habían defendido sus tesis doctorales en el extranjero (Hernández en la U. de Friburgo; Matus, en la U. Autónoma de Barcelona); pero ninguno era profesor de

\footnotetext{
${ }^{186}$ El texto del Anteproyecto elaborado por la Comisión Foro Penal y sus Materiales de Discusión, preparados por los miembros de su Secretaría Técnica, Srs. Héctor Hernández y Jean Pierre Matus, así como un conjunto de artículos dedicados a su discusión, se encuentran en Polit. crim., N ${ }^{\circ} 1$ (2006), disponible en Internet en http://www.politicacriminal.cl [visitada por última vez el 20.03.2010]

${ }^{187}$ Véase Supra, nota al pie $\mathrm{n}^{\mathbf{0}} 163$, y el texto a que hace referencia.

${ }^{188}$ Por todas, baste la clásica POLITTOFF, Sergio; BUSTOS R., Juan; GRISOLÍA, Francisco, Derecho penal chileno, parte especial, Santiago de Chile: Ed. Jurídica de Chile, 1971, 396 pp.

${ }^{189}$ Véase Derecho penal, cit. nota $\mathrm{n}^{\mathrm{0}} 156$.

${ }^{190}$ Véase su Derecho penal, cit. nota ${ }^{\circ} 64$.

${ }^{191}$ Ha publicado cuatro tomos en varias ediciones de su Derecho penal, que comprenden tanto la parte general como la especial (Santiago de Chile: Ed. Jurídica de Chile, 1997-)

${ }_{192}$ Aunque Ortiz no ha participado en la elaboración de ninguna obra comprensiva del Derecho penal chileno, pero su valía como abogado del Foro y Profesor de Derecho penal de diversas generaciones, incluyendo a este autor, es innegable.

${ }^{193}$ Véase la nota $\mathrm{n}^{\mathrm{o}} 188$ y nuestras Lecciones de Derecho Penal, cit. nota $\mathrm{n}^{\mathrm{o}} 16$.

${ }^{194}$ Sobre la vida e influencia de Sergio Yáñez, formador de importantes profesores actuales, como Miguel Soto P., entre otros, véase MATUS, Jean Pierre, "Sergio Yáñez, obra e influencia: la dogmática chilena actual”, en Revista de derecho (Coquimbo), pp. 113-130.
} 
Polit. crim. Vol. 5, No 9 (Julio 2010), Art. 4, pp. 143-206.

[http://www.politicacriminal.cl/Vol_05/n_09/Vol5N9A4.pdf]

la Universidad de Chile o la P. Universidad Católica, sino de las recientemente creadas Universidad Alberto Hurtado y de Talca, respectivamente.

\subsubsection{Procedimientos de trabajo}

La misma Res. Exenta estableció el Reglamento de Trabajo correspondiente, y nombró al "cuerpo de especialistas" de todos los sectores políticos que serían los miembros el Foro Penal, ${ }^{195}$ encargados de estudiar, aprobar o rechazar las propuestas de articulado presentadas por la Secretaría Técnica, como asimismo formular sugerencias $u$ observaciones a las mismas. En este grupo se designaron la mayor parte de los profesores de Derecho Penal de las Universidades de Chile y Católica, más algunos de provincia, de universidades privadas y jóvenes profesionales con estudios en el extranjero. Sin embargo, no se designaron Ministros o Subsecretarios, Diputados o Senadores, o Miembros de los Tribunales Superiores de Justicia. Tampoco se designaron representantes nominativos de la Fundación Paz Ciudadana o de la Corporación de Promoción Universitaria, tan relevantes para el proceso de recodificación procesal. Hubo, en todo caso e informalmente, invitaciones a personas de instituciones como el Ministerio Público y la Defensoría Penal Pública.

El Reglamento del Foro Penal establecía una rígida mecánica del trabajo, con el propósito de lograr completar el trabajo dentro de un plazo razonable, fijado en un principio en dos años: la Secretaría Técnica remitía con anticipación de al menos una semana a los miembros del Foro los Materiales de Discusión y el Articulado Propuesto para cada unidad de trabajo, se recibían eventualmente observaciones que se discutían con sus autores en pequeñas reuniones, y el texto del articulado así revisado se sometía a la votación global de la asamblea del Foro, que se reunía regularmente los días jueves en la tarde. Para lograr soluciones "consensuadas" por la mayor parte de los miembros del Foro, el Reglamento establecía, además, un elevado quórum de aprobación de los proyectos (mayoría absoluta de los miembros de foro) y ponía sensibles trabas para la discusión de propuestas alternativas, las que debían presentarse fundamentadas y por escrito, con anterioridad a las sesiones. Con el tiempo y las prisas, durante el último año de sesiones el Articulado Propuestos era sometido directamente a discusión ante la Asamblea y los cambios se efectuaban en el mismo momento, gracias al uso de las tecnologías modernas.

\subsection{Divisiones y ausencias al interior del Foro Penal}

Prontamente, las diferencias entre los miembros del Foro, que terminaban resolviéndose en votaciones no siempre favorables a algunos de ellos, produjeron varias crisis entre los miembros del Foro Penal, que inevitablemente afectaron la valoración del Proyecto:

Respecto al Consejo Directivo, al finalizar el primer año y discutirse el sistema de penas propuesto por la Secretaría Técnica, el entonces Presidente del Consejo Directivo,

\footnotetext{
195 Según el número 9 del Decreto 443, estos “especialistas" deberían haber "ejercido influencia en nuestro medio en virtud de su trayectoria académica, de sus publicaciones o de su desempeño en el ejercicio de la profesión de abogado"; o encontrarse "en posesión de una cátedra del ramo en alguna Universidad reconocida por el Estado; o estar "dotados del título de Doctor o MG [sic] en Derecho penal".
} 
Alfredo Etcheberry, fue el único miembro en votar en contra de la propuesta, ${ }^{196}$ retirándose al año siguiente, y provocando, de paso, una suspensión de los trabajos por un lapso de dos meses durante el año 2004, hasta que Enrique Cury asumió la Presidencia y se reiniciaron los trabajos.

Al retiro de Etcheberry del Consejo Directivo, debía sumarse el hecho de que tampoco se podía contar, por razones de salud, con Sergio Yáñez, quien asistió sólo ocasionalmente; por su parte, por encontrarse en el extranjero, Sergio Politoff no asistió nunca; y por estar dedicado prácticamente por completo a la vida política, tampoco lo hizo Juan Bustos, entonces Diputado. Así, al finalizar la redacción del Anteproyecto, el Consejo Directivo estaba reducido, en la práctica, a los profesores Cury, Ortiz y Garrido Montt.

En cuanto a los miembros del Foro Penal, en las primeras sesiones se retiró Antonio Bascuñán R., profesor de la Universidad de Chile, cuya Propuesta Alternativa sobre "aplicación de la ley en tiempo", tras breve debate, no fue considerada, aduciéndose entre otras razones que no había sido presentada a tiempo. Durante el segundo año, la Profesora de la Universidad de Chile María Inés Horvitz dejó de asistir, luego de que se aprobase la propuesta sobre delitos de aborto que no contenía ninguna modificación sustantiva a la regulación vigente desde 1874, con una muy breve discusión, aduciéndose que, por reglamento, no podía discutirse una alternativa como la del "sistema de plazos" u otra que no se había presentado previamente por escrito. Por su parte, el Profesor Miguel Soto P., también de la Universidad de Chile, asistió irregularmente, manifestando en todo momento su disconformidad con el rígido procedimiento, que limitaba las alternativas a discutir al momento de su votación.

Justificada o no, la sensación de división y escaso apoyo de los principales profesores de la Universidad de Chile al Proyecto entregado a fines de 2005, llegó a las páginas de la prensa nacional, en un Reportaje publicado el día Domingo 30 de julio de 2006 por el Diario El Mercurio, significativamente titulado "Guerra Civil por el Código penal". Allí no solamente aparecen distanciándose del Proyecto los ya mencionados Profesores de la Universidad de Chile Bascuñán, Etcheberry, Horvitz, y Soto, sino también el de uno de los más influyentes asesores del Senado por su participación en el proceso de Reforma Procesal Penal, el profesor Jorge Bofill, y el entonces Director del Departamento de Ciencias Penales de la Universidad de Chile, Vivian Bullemore, quien había dejado de asistir a las reuniones del Foro Penal el mismo año 2003. ${ }^{197}$

En la carta de respuesta a este Reportaje, enviada por buena parte de los Miembros del Foro, su Consejo Directivo y Secretaría Técnica, no se niega la división producida ni el abandono del proyecto por parte de los profesores antes mencionados, pero se matiza en cuanto a las razones esgrimidas para ello:

"Como es fácil de comprender, en un debate donde se cita a discutir a un número importante de académicos siempre habrá diferencias de opinión. Y efectivamente, ellas existieron en las sesiones del Foro Penal. Pero siempre se procuraba

\footnotetext{
${ }^{196}$ La propuesta de Etcheberry, que incluye no sólo una importante reducción del uso de la cárcel, sino también medidas de seguridad postdelictuales, puede verse en el Discurso con que recibió el título de Doctor Honoris Causa de la Universidad de Talca, citado Supra, nota $\mathrm{n}^{\mathrm{o}} 185$.

197 Véase el texto completo del Reportaje citado en http://diario.elmercurio.cl/detalle/index.asp? $\mathrm{id}=\{9 \mathrm{f} 9254 \mathrm{ea}-\mathrm{b} 4 \mathrm{f1}-4 \mathrm{cae}-\mathrm{a} 31 \mathrm{e}-74670 \mathrm{e} 87 \mathrm{a} 27 \mathrm{a}\}$ [visitado por última vez el 20.03.2010].
} 
Polit. crim. Vol. 5, No 9 (Julio 2010), Art. 4, pp. 143-206.

[http://www.politicacriminal.cl/Vol_05/n_09/Vol5N9A4.pdf]

escucharlas, debatir su contenido y llegar a acuerdos aceptables por la mayoría de los concurrentes. Es por ello que, por su naturaleza de obra común, no todos estamos plenamente de acuerdo con la totalidad de las decisiones adoptadas, pero sí con la forma y resultado de nuestro trabajo." ${ }^{198}$

\title{
3.4. La pérdida del apoyo político del Proyecto en el Gobierno de Michelle Bachelet (2006-
} 2010)

Aunque podría ser esperable que, siendo el Gobierno de Michelle Bachelet una continuación de los anteriores de la Concertación de Partidos por la Democracia, las políticas de Reforma del Sistema Criminal iniciada en los anteriores continuasen, lo cierto es que los Ministros de Justicia de esta última administración rápidamente hicieron ver su disconformidad con el texto preparado por la Comisión Foro Penal.

En efecto, en el mismo Reportaje del Diario El Mercurio citado en el apartado anterior, el entonces nuevo Ministro de Justicia, Isidro Solís, declaraba su intención de formar "un comité para que le dé un hilo conductor al proyecto", al que, a reglón seguido, consideraba propiamente una "Comisión Redactora", que "debería tener escrito el texto este año, de modo que podamos buscar los consensos el primer semestre del próximo año, y así estar con el proyecto en el Congreso en el segundo semestre de 2007." Como alternativa, proponía la división del Proyecto en dos partes, enviando a discusión parlamentaria sólo la referida a aspectos menos problemáticos de la Parte General, y "y reservar la parte especial -de las penas- para un momento en que la serenidad y el rigor técnico permitan discutir seriamente" (sic).

Con la abrupta salida de Solís del Ministerio de Justicia a principios del año 2007 y su reemplazo por Carlos Maldonado, las ideas antes señaladas quedaron en el aire. El Ministro Maldonado no tuvo ningún acercamiento con los miembros del Consejo Directivo o de la Secretaría Técnica del Foro Penal, no habiéndose presentado en público, hasta el fin de su gestión, ninguna información acerca del resultado de los trabajos de la "Comisión Redactora" que habríase organizado en 2006.

\subsection{El Anteproyecto de 2005}

\subsubsection{Modelos, trabajo preparatorio y textos de referencia}

Según el no 2.1. del Decreto $\mathrm{N}^{\circ} 443$ de 12 de junio de 2004, que creó la Comisión Foro Penal, ésta debía considerar para la preparación del Anteproyecto:

\begin{abstract}
"las soluciones ofrecidas por la legislación nacional vigente, tanto en lo que respecta al Código penal como a las leyes extravagantes, críticamente apreciadas conforme al estado de la cuestión en la doctrina y la jurisprudencia nacionales, así como a la luz de los modelos de solución ofrecidos por los sistemas comparados históricamente más cercanos a nuestra tradición"
\end{abstract}

\footnotetext{
${ }^{198}$ El Mercurio, 8 de agosto de 2006, p. A2. La carta está suscrita por Enrique Cury, Mario Garrido Montt, Luis Ortiz, Carlos Künsemüller, Eduardo Novoa Aldunate, Miguel Schweitzer, Juan Domingo Acosta, Claudio Feller, Jorge Gálvez, René García, Héctor Hernández, Joanna Heskia, Karin Künsemüller, Fernando Londoño, Francisco Maldonado, Jean Pierre Matus, Juan Carlos Manríquez, María Cecilia Ramírez, Jaime Retamal, María Elena Santibáñez, Miguel Vivieros, Myrna Villegas y Raúl Carnevali.
} 
MATUS, JEAN PIERRE. "La doctrina penal de la (fallida) recodificación chilena del Siglo XX y principios del XXI".

En atención a lo anterior, al momento de redactarse las propuestas normativas, se realizó más bien un trabajo de revisión del Código penal vigente y de las leyes penales especiales, antes que la adopción de modelos completos extranjeros. La sistemática del Anteproyecto se ajustó, además, en cuanto varió de la del Código actualmente vigente, a la ordenación de las materias en los textos de estudio al uso entre nosotros. Raramente se tomaron en consideración normas extranjeras para su trasposición literal $o$ modificada, aunque, a través de la literatura nacional, se tuvo siempre en cuenta el estado de la doctrina alemana y española disponible.

Luego, para la detección de los problemas existentes en la legislación vigente y ofrecer soluciones a los mismos, se recurrió generalmente a los textos nacionales, y principalmente a las Lecciones de Derecho Penal, Parte General y Parte Especial, en cuya preparación había participado activamente uno de los miembros de la Secretaría Técnica, Jean Pierre Matus. ${ }^{199}$

Para el trabajo de fijación y ordenamiento de la normativa penal extravagante, se recurrió a un Informe preparado por el mismo Jean Pierre Matus durante el año 2002, que contenía todos los tipos penales vigentes a la fecha, ordenados según bien jurídico, junto a recomendaciones de supresión por redundancia o imposible aplicación. El Informe daba cuenta que a esa fecha la mayor parte de la frondosa legislación especial dictada durante las etapas de expansión de la actividad empresarial del Estado (19251973) habían sido ya derogada, subsistiendo únicamente alrededor de 1.250 tipos penales, entendiendo por tales, figuras que describían conductas sancionadas con penas privativas de libertad o con multas impuestas por tribunales en lo criminal. Sin embargo, la mayor parte de ellos no crean nuevos delitos, sino que modifican las tipificaciones del Código para nuevas circunstancias, restando requisitos o haciéndolas extensivas a situaciones que no existían en el siglo XIX. Particularmente significativo es el número de tipificaciones para fraudes de subvenciones varias y presentación de documentos o declaraciones falsas ante nuevas autoridades e instituciones. El Informe proponía, por lo tanto, más que incorporar todas esas modalidades delictivas a un nuevo Código, redactar nuevas normas generales o modificar las reglas del Código existente, para dar cuenta de ellas. Finalmente, se proponía una sistematización de la parte especial que diera cuenta de las valoraciones actuales, comenzando por los delitos contra la vida e incorporando algunos nuevos títulos que dieran cuenta de los cambios valorativos acaecidos a la fecha. Se propone, además, que los cuasidelitos y faltas se describan y sancionen en los respectivos títulos de los bienes jurídicos que afectaría, para determinar si realmente es necesario su castigo penal y en qué medida. ${ }^{200}$

Para una de las principales innovaciones del Anteproyecto, la regulación medioambiental y las "normas comunes" de los delitos de peligro común, se recurrió también a un trabajo de investigación anterior dirigido por Jean Pierre Matus sobre la misma materia, que había concluido con la presentación de una propuesta normativa. ${ }^{201}$

${ }^{199}$ La Parte General está citado Supra, nota $n^{\circ} 16$, cuya primera edición es del año 2003. La primera edición de la Parte Especial apareció a fines de 2004, pero su trabajo preparatorio databa de un buen par de años antes.

${ }^{200}$ MATUS, Jean Pierre, Informe final, Proyecto sistematización de tipos penales vigentes en Chile (Ministerio de Justicia), Inédito.

${ }^{201}$ MATUS, Jean Pierre (Ed.), Derecho Penal del Medio Ambiente. Estudios y propuesta para un nuevo Derecho penal ambiental chileno, Santiago: ed. Jurídica de Chile, 2004, 246 pp. La fecha de publicación del trabajo recopilatoria final es algo posterior a la de los textos que contiene, dado que el proyecto había terminado de ejecutarse precisamente el año 2002. 
Polit. crim. Vol. 5, No 9 (Julio 2010), Art. 4, pp. 143-206.

[http://www.politicacriminal.cl/Vol_05/n_09/Vol5N9A4.pdf]

Para otro de los claros cambios frente a la legislación anterior, la regulación de los delitos contra la propiedad y el patrimonio, se contó con los conocimientos y trabajos previos en la materia de Héctor Hernández, el otro de los redactores de la Secretaría Técnica. ${ }^{202}$

Para los casos en que habían recientes cambios más o menos relevantes en las leyes especiales o en el propio código, se optó por considerar que tales cambios reflejaban las valoraciones sociales actuales y que, por lo tanto, sólo correspondía mantenerlos o incorporarlos al Código, modificando únicamente los aspectos técnicos que podrían presentar dificultades de aplicación. A la inversa, el entonces abierto debate que reflejaba la falta de acuerdo político acerca de los delitos contemplados en el Derecho penal Internacional y, particularmente, en el Estatuto de Roma, llevó a que no se propusiera una regulación especial al respecto, entendiendo que la mayor parte de los delitos que se trata podrían ser reconducidos de una $u$ otra manera a las figuras tradicionales.

\subsubsection{El contenido del Anteproyecto}

El Anteproyecto contiene 417 artículos, divididos en dos Libros. No tiene disposición final derogatoria, por que no alcanzó a discutirse.

Según Fernández,

"De una lectura del articulado del APCP puede apreciarse una estructura político criminal liberal -sustentada en los en los principios de proporcionalidad y culpabilidad- y una depuración de gran parte de las disposiciones anacrónicas y superfluas del actual CP. También puede observarse que ha incluido gran parte de figuras penales que en la actualidad de encuentra en leyes penales especiales, recuperando así el espíritu de la codificación; y por último, ha iniciado un necesario proceso de modernización incluyendo dentro de su ámbito de protección bienes jurídicos o intereses como el medio ambiente y el orden socioeconómico". 203

En efecto, el Libro Primero, contempla cinco Títulos, siguiendo un orden muy similar al del Código de 1874: el I trata de los delitos y de las circunstancias que eximen de la pena, la atenúan o la agravan. Contiene una definición dogmática de delito (art. $1^{\circ}$ ); elimina la división tripartita y la reduce sólo a crímenes y simples delitos (art. $2^{\circ}$ ); contiene una regulación del error que recoge la dominante, entre nosotros, "teoría moderada de la culpabilidad" (arts. $3^{\circ}$ y $4^{\circ}$ ); no innova en la definición de tentativa y frustración, aunque pretende mejorar la del desistimiento (art. $5^{\circ}$ ); amplía el estado de necesidad a la comisión de cualquier delito (art. $6^{\circ}, 5^{\mathrm{a}}$ ), pero mantiene el resto de las eximentes intactas, salvo la supresión de la legítima defensa privilegiada (art. $6^{\mathrm{o}}, 4^{\mathrm{a}}$ );

${ }^{202}$ Véase, por ejemplo, HERNÁNDEZ B., Héctor, "Aproximación a la problemática de la estafa", en: VV. AA., Problemas actuales de Derecho Penal, Temuco: Universidad Católica de Temuco, 2003, pp. 148-190.

${ }^{203}$ FERNÁNDEZ C., José Ángel, "El Nuevo Código Penal: una lucha por el discurso de la criminalidad", Polít. crim. $\mathrm{N}^{\circ} 1$ (2006), A5, pp. 1-30, p. 2s., quien cree, en todo caso, que el Anteproyecto no debiera ser sometido a deliberación parlamentaria, para no ser "objeto de los mismos criterios de irracionalidad, discriminación y falta de rigor técnico que los acaecidos en las últimas reformas penales en materia de tráfico de drogas, delitos contra la propiedad y contra la libertad sexual e indemnidad sexual" (p. 3). 
mantiene las principales circunstancias atenuantes vigentes hoy en día y agrega las del motivo piadoso o altruista (art. $7^{\mathrm{o}}, 2^{\mathrm{a}}$ ) y la de "análoga significación" (art. $7^{\mathrm{o}}, 6^{\mathrm{a}}$ ); reduciendo, en cambio, las circunstancias agravantes a sólo tres: alevosía, precio o recompensa y ensañamiento, permitiendo su apreciación facultativa $\left(\operatorname{art} .8^{\circ}\right)^{204}$. En cuanto a los responsables del delito, regulados en el Título II, se suprime a los encubridores y las calificaciones del actuar artículo 15, pero se agrega la categoría de "autoría mediata", siguiendo la fórmula del Código español de 1995 (art. 10, 2º). El Título III establece las reglas de aplicación de la ley en el tiempo, las personas y el espacio, sin ofrecer mayores novedades que arreglos técnicos y la incorporación de una regulación expresa para la ultractividad (art. 16) y las leyes temporales (art. 15). El título IV, de las penas, contiene una regulación que externamente sigue la estructura del actual Código, con escalas penales incluidas, y rebajas obligatorias para los distintos grados de participación ${ }^{205}$ y ejecución de delito (salvo en el de la tentativa, cuyo segundo grado se hace facultativo) a) se suprimen las penas perpetuas; b) se propone un único sistema concursal de acumulación material con un límite de hasta 30 años (art. 53); c) al incorporar al Código las reglas de suspensión y remisión condicional de la pena (que pasa a llamarse "observación discreta"), se limita su aplicación únicamente a los simples delitos; dejando a los condenados por crímenes sólo la posibilidad de una libertad vigilada en casos excepcionales; y d) lo anterior, más la incorporación de las reglas de ejecución de la pena y libertad condicional, posibilitan al ciudadano y al legislador una previsión más precisa de los efectos de la comisión de un crimen o simple delito. Finalmente, el Título $\mathrm{V}$ trata de la extinción de la responsabilidad penal y no contiene más novedad que la introducción de algunas reglas de similar efecto contenidas en el Código Procesal Penal (acuerdo reparatorio, suspensión condicional del procedimiento y principio de oportunidad).

El Libro II contiene 16 Títulos. El primero, trata del homicidio y las lesiones, y su mayor reforma consiste en la elevación significativa de las penas para estos delitos: El homicidio simple pasa a ser castigado con penas de diez a quince años (art. 80) y el calificado, con quince a veinte (art. 81); se suprimen el parricidio y el infanticidio, pero se agrega un nuevo homicidio calificado, el que se "perpetre con motivo u ocasión de la comisión de otro delito", estableciéndose un caso agravado cuando tales delitos son el secuestro, la violación de menores, las torturas, el robo o la violación (art. 82); en sentido contrario, el homicidio "por motivos piadosos" aparece como una figura privilegiada, con una pena de cinco a diez años (art. 83). El auxilio al suicidio mantiene una descripción y penalidad similar a la actual, la misma que se aplica para su inducción (art. 84); pero las lesiones se modifican drásticamente en su descripción, suprimiéndose el sistema de duración de la enfermedad para su calificación (arts. 85-88). El Título II regula el aborto, manteniendo básicamente la prohibición absoluta que contempla la actual legislación, salvo correcciones técnicas menores (arts. 92-95). ${ }^{206}$ El III, el abandono de personas desvalidas y la omisión de socorro. El primero se trata en una

\footnotetext{
204 Al respecto, véase RAMÍREZ, María Cecilia, "Anteproyecto de Código Penal: hacia una racionalización de las circunstancias modificatorias de responsabilidad penal. El caso de las agravantes", Polit. crim. No4 (2007), A2, p. 1-22.

205 Sobre la regla particular de comunicabilidad de las circunstancias personales entre cómplices y partícipes (art. 45 del Anteproyecto), véase OSSANDÓN, Ma Magdalena. "Delitos especiales y de infracción de deber en el Anteproyecto de Código Penal”, Polít. crim. N 1 (2006), A4, p. 1-22.

${ }^{206}$ Las críticas de María Inés Horvitz a esta regulación, hechas en la discusión del Foro Penal, se plasmaron después en el texto HORVITZ L., María Inés ; SOTO P., Miguel, “Consideraciones críticas sobre la regulación del delito de aborto en el anteproyecto de nuevo código penal elaborado por el foro del Ministerio de Justicia”, Revista de Estudios de la Justicia, no 9 (2007), pp. 75-120.
} 
única y simplificada disposición general (art. 96); mientras la omisión de socorro se eleva a la calidad de simple delito, pero se transforma en delito especial, que sólo pueden cometer los encargados de los servicios de salud y policiales (art. 97).

El título IV regula los delitos contra la integridad sexual, manteniendo, como se ha dicho, las valoraciones incorporadas al Código penal por las últimas reformas importantes en la materia. ${ }^{207}$ El Título V, trata de los delitos contra la libertad y la seguridad personal, también sin grandes variaciones frente a la situación actual, salvo las inevitables modificaciones técnicas. Lo mismo acontece con el tratamiento de las injurias, Título VI, al que se incorporan las reglas de la legislación especial vigente, sobre difusión de informaciones de inertes público. El Título VII, trata los delitos contra la intimidad, procurando una regulación más precisa de las intervenciones y grabaciones subrepticias, que no criminalice su difusión en caso de existir un "interés público comprometido" (art. 137).

El título VIII, trata los delitos contra la propiedad y el patrimonio, alterando de manera radical la configuración actual: la figura de daños pasa al párrafo 1; la apropiación indebida y el hurto de hallazgo se regulan en el mismo párrafo 2, aunque sin otras grandes alteraciones; en el párrafo 3 se elimina la calificación del hurto según la cuantía de los sustraído (art. 148); la mayor parte de los casos que hoy se conocen como "robo con fuerza", pasan a ser "hurtos agravados" (Art. 149); y se establece el delito de hurto de uso de vehículos motorizados (art. 150); en el párrafo 4 se establece un único caso de robo con fuerza, el que se comete "en lugar habitado" (art. 152); en el 5, se regulan el robo violento y la extorsión, con penas significativamente inferiores a las actuales (arts. 153 y 154) ${ }^{208}$ En cuanto a los delitos patrimoniales, la novedad es la simplificación de la estafa a una figura genérica (art. 19) y la incorporación de los delitos de fraude informático (art. 160), administración fraudulenta (art. 161) y obtención indebida de suministros (art. 163) y 162).

El título X, como hemos dicho, es el que contiene la mayor novedad en cuanto a la propuesta punitiva, incorporando a nuestro ordenamiento los delitos relativos al medio ambiente (arts. 167 a 173), ${ }^{209}$ y reglas comunes que pretenden hacer posible y efectiva la sanción de las grandes organizaciones actuales y sus representantes, quienes los que controlan las mayores fuentes de peligro (arts. 228 a 233). ${ }^{210}$ Además, dicho título contempla normas contempladas actualmente tanto en el Código penal como en leyes

\footnotetext{
${ }^{207}$ Un análisis crítico del mismo puede verse en RODRÍGUEZ-COLLAO, Luis, "Sobre la regulación de los delitos contra la integridad sexual en el Anteproyecto de Código Penal”, Polít. crim. No 1 (2006), A1, pp. 1-19.

${ }^{208}$ KÜNSEMÜLLER, Carlos., "Los principios cardinales del ius puniendi a la luz de algunos delitos contra la propiedad contemplados en el Anteproyecto de Código Penal redactado por el Foro Penal," Polit. crim. $\mathrm{N}^{\mathrm{o}} 1$ (2006), A3, pp. 1-14, donde se valora la simplificación del texto (con la supresión de agravantes especiales y todo el régimen de "reglas comunes" actualmente vigente) y las reducciones punitivas que se proponen, pero se critica especialmente la mantención del delito de robo con fuerza en lugar habitado (p. 7s).

${ }^{209}$ Una crítica general y negativa respecto del articulado propuesto en materia de protección del medio ambiente, véase en BASCUÑÁN, Antonio, "Comentario crítico a la regulación de los delitos contra el medio ambiente en el anteproyecto de Código Penal de 2005”, Estudios Públicos, № 110 (2008), pp. 241322.

${ }^{210}$ Poniendo en duda la utilidad de una de esas reglas, la que regula la prueba de la causalidad en estos casos (art. 232), véase HERNÁNDEZ, Héctor, "El problema de la "causalidad general" en el derecho penal chileno (con ocasión del art. 232 del Anteproyecto de Nuevo Código Penal)", Polit. crim. N 1 (2006), A7, p. 1-33.
} 
MATUS, JEAN PIERRE. "La doctrina penal de la (fallida) recodificación chilena del Siglo XX y principios del XXI".

especiales, reformadas técnicamente para reprimir los delitos relativos a la pesca, caza y salud animal (arts. 174 a 181); los incendios, los delitos relativos a la energía nuclear y otros estragos (arts. 182 a 190); los delitos relativos a la manipulación genética (art. 191); el expendio de sustancias medicinales, bebidas y alimentos nocivos para la salud y otros delitos contra la salud pública (arts. 192 a 198); el tráfico ilícito de estupefacientes y sustancias psicotrópicas (arts. 200 a 214); y los que dicen relación con la seguridad de los medios de transporte, entre los que se incluye expresamente la figura del "piedrazo" en la carretera (art. 224).

Los restantes títulos del Libro II tratan con el mismo propósito general de mejorar las redacciones actuales, incorporando la legislación especial extravagante para evitar lagunas y superar contradicciones, aunque sin ofrecer grandes novedades, las falsedades (Título X); los delitos contra la administración pública (Título XI); los contra la administración de justicia (Título XII), a donde vienen a parar el encubrimiento (art. 277), la receptación (Art. 278) y el lavado de dinero (art. 279); los delitos contra la propiedad intelectual, industrial, el sistema financiero y otros intereses económicos (Título XIII), donde se refunde toda la dispersa legislación existente en la materia; lo miso que sucede en el Título XIV, delitos contra el orden público; en el XV, delitos contra la seguridad interior del Estado, que se hace cargo de las disposiciones de las leyes de Seguridad del Estado y sobre Conductas Terroristas; ${ }^{211}$ y en el XVI, sobre seguridad exterior y soberanía del Estado.

\subsection{El futuro del Anteproyecto de 2005}

Conforme a lo antes expuesto, el Anteproyecto de Código penal de 2005 puede verse principalmente como un trabajo de revisión, fijación y unificación "técnica" del Derecho penal vigente a la época de su elaboración, fundado en la literatura e investigaciones previas disponibles, pero sin pretensiones de transformación $o$ adecuación del mismo a una clara política criminal, salvo quizás en tres aspectos más o menos distinguibles: a) en la Parte General, la tímida distinción entre crímenes y simples delitos frente a las medidas de suspensión condicional de la pena y remisión condicional de la misma ("discreta observación de la autoridad"), en que parece esbozarse la posibilidad de que, al menos frente a los crímenes, la discreción judicial y el juego de atenuantes y agravantes no alteren significativamente la voluntad del legislador; b) En la Parte Especial, la introducción de un derecho penal ambiental moderno; y c) una nueva regulación de ciertos delitos tradicionales: homicidios y robos y hurtos.

Sin embargo, hemos dicho que la fijación "técnica" no es el propósito de un Código penal, sino el de hacer compatible la regulación punitiva con un cambio de valoraciones sociales del que ya no da cuenta la anteriormente vigente. Desde este punto de vista, ese cambio no lo propone el Anteproyecto, pues no enfrenta la cuestión del para qué se cuenta con un sistema punitivo (y por eso le es fácil adaptarse al del Código de 1874), ${ }^{212}$ ni tampoco sus redactores - un cuerpo de profesores de Derecho penal- estábamos en

\footnotetext{
${ }^{211}$ Crítica de esta regulación, véase VILLEGAS, Myrna, "Los delitos de terrorismo en el Anteproyecto de Código Penal", Polít. crim. № 2 (2006), A3, pp. 1-31.

${ }^{212}$ Esta falta de un verdadero y coherente programa de política criminal, puede verse con claridad al revisar, por ejemplo, las atenuantes y agravantes: mientras se rechaza la agravante de reincidencia por representar un "derecho penal de autor", se acoge con entusiasmo la de "irreprochable conducta anterior", aunque tienen igual fundamento.
} 
condiciones de acceder, salvo por sus reflejos en las recientes legislaciones (¡que ya eran pasado!), a los reclamos sociales en orden al cómo y qué debería o no ser prohibido, y en qué medida, por un nuevo texto punitivo (y por eso nos fue fácil plantear reformas "técnicas" a las legislaciones dispersas y nuevas, sin alterar su contenido valorativo).

Otra explicación a este inmovilismo, más pesimista, sería que efectivamente refleja el estado actual de las valoraciones sociales y que no hay espacio, hoy en día, para un cambio en el sentido de la función del sistema punitivo y de lo que se estima permitido o prohibido. ${ }^{213} \mathrm{Si}$ esto es cierto, con mayor razón no estarían dadas las condiciones para una verdadera (re)codificación, sino, a lo más, para una fijación técnica del derecho penal vigente.

En ambos casos, el Anteproyecto sería superfluo.

Contaba, eso sí, el Proyecto, con grandes figuras nacionales que, en un principio, lo respaldaban, como los miembros de su Consejo Directivo. Sin embargo, dado que este Consejo no estaba realmente a cargo de la redacción del articulado, su desapego por el mismo es comprensible. El abierto abandono del Proyecto por Etcheberry fue una señal más que clara de ese desapego. Tampoco debe olvidarse que, sea por las razones que fueren, buena parte de los profesores y el Director el Departamento de Ciencias Penales de la Universidad de Chile, todavía una de las más importantes e influyentes del país, abandonó el Proyecto. Estas divisiones y deserciones habilitaban al Ministerio de Justicia para dejar de lado, como efectivamente lo hizo, la idea de una codificación en base a un Anteproyecto con tan formidables detractores.

Concebido principalmente como una reforma y unificación técnica del Código penal de 1874 y las numerosas legislación penal extravagante, con fuerte oposición de un sector importante de la academia y ya anticuado en varios sentidos, ${ }^{214}$ el futuro del Anteproyecto no parece auspicioso. Además, perdido el apoyo político de la Concertación de Partidos por la Democracia, no se ve fácil que pueda conseguirlo del nuevo Gobierno de la coalición contraria, que acaba de asumir bajo la presión de las graves urgencias provocadas por la naturaleza.

No obstante, el mismo carácter "técnico" y "unificador" del Anteproyecto puede servirle para ser aceptado por el nuevo Gobierno como base de discusión de un Proyecto, que revisado por una Comisión "del más alto nivel”, pueda ser ajustado a su propia política criminal, que probablemente no sea otra que la que ya vivimos, con ciertos matices. $^{215}$

\footnotetext{
${ }^{213}$ Este es el sentido del texto antes citado de FERNÁNDEZ, "Nuevo Código Penal", cit. nota no 203.

214 Por ejemplo, ya se ha incorporado a nuestra legislación la responsabilidad penal de las personas jurídicas y un nuevo régimen de responsabilidad penal de los adolescentes: delitos contra la humanidad y demás contemplados en el Estatuto de Roma; e importantes modificaciones respecto de los delitos relativos a la violencia doméstica, etc., por mencionar sólo algunos aspectos que el Anteproyecto de 2005 omite.

${ }^{215}$ De nuevo, véase al respecto el texto de antes citado de FERNÁNDEZ, "Nuevo Código Penal", cit. nota $\mathrm{n}^{\circ}$ 203, cuyo diagnóstico acerca del "consenso" de toda la clase política nacional con la actual política criminal, que él califica de "neoliberal", es coincidente con el diagnóstico de CORREA/FIGUEROA/JOCELYN-HOLT/ROLLE/VICUÑA, Historia, cit. nota no 94, p. 339 y ss., acerca del "estancamiento" que en la vida social y la discusión pública ha supuesto este "consenso" promovido por los Gobiernos de la Concertación Por la Democracia desde 1989 hasta el presente, cuyas
} 
MATUS, JEAN PIERRE. "La doctrina penal de la (fallida) recodificación chilena del Siglo XX y principios del XXI".

Es claro, entonces, que para un nuevo Código Penal así aprobado, bien valdrán las palabras de Lampedusa:

"Si queremos que todo siga como está, es preciso que todo cambie. ¿Me explico?", 216

\section{BIBLIOGRAFÍA CONSULTADA}

ABARZA, René; MATUS, Jean Pierre (Prof. Guía), Pedro Pablo Ortiz Muñoz. Vida, obra e influencia en el Derecho penal chileno., Talca: U. de Talca (Memoria de Prueba), 2005, $55 \mathrm{pp}$.

Actas de las sesiones de la Comisión Redactora del Código Penal Chileno, Santiago: Imp. de la República, 1873, 314 pp.

ALESSANDRI PALMA, Arturo, Recuerdos de Gobierno, Administración 1932-1938, $t$. III, Santiago de Chile: Ed. Nascimento, 1967, 592 pp.

ALVEAR, Soledad, Reforma penal: un aporte a la consolidación de la convivencia social, Intervención de la Ministra de Justicia al inaugurar el trabajo del Foro Penal, Santiago, documento inédito, 2 de agosto de 1999.

AMUNÁTEGUI, Miguel Luis, Vida de Bello, Santiago de Chile: Imp. P. Ramírez, 1882, 672 pp., disponible en Internet en http://www.archive.org/stream/vidadedonandrsb00amungoog\#page/n687/mode/1u p [visitado por última vez el 15.03.2010].

ANGUITA, René, Leyes Promulgadas en Chile, t. II, Santiago: Imp. Barcelona, 1912, $930 \mathrm{pp}$.

ASTICA, María, "La asistencia social en los estados antisociales", Revista de Ciencias Penales, t. XI (1949), pp. 74-83

BARBERO, Marino, "La fundamentación doctrinal y la orientación político-criminal del Código penal chileno en el panorama actual del Derecho penal", en RIVACOBA, Manuel (Ed.), Actas de las Jornadas Internacionales de Derecho penal en celebración del centenario del Código penal chileno, Valparaíso: Edeval, 1975, 398 pp., pp. 35-41

BARROS, Enrique, "Alfredo Jocelyn-Holt: El peso de la noche. Nuestra Frágil Fortaleza Histórica”, Revista de Estudios Públicos, 70 (1998), pp. 301-307.

BASCUÑÁN R., Antonio, Observaciones sobre la Reforma del Código Penal (Intervención en la Jornada de Reflexión convocada por el Ministerio de Justicia el día Lunes 2 de Agosto de 1999), Documento inédito, 8 pp.

BASCUÑÁN V., Antonio, El delito de abusos deshonestos, Santiago de Chile: Ed. Jurídica, 1961, 159 pp.

BASCUÑÁN, Antonio, "Comentario crítico a la regulación de los delitos contra el medio ambiente en el anteproyecto de Código Penal de 2005", Estudios Públicos, $\mathrm{N}^{\mathrm{o}} 110$ (2008), pp. 241-322.

planteamientos políticos y reformas terminaron por consolidar el sistema político y económico heredado de la Dictadura militar, y la tuición militar y eclesiástica en buena parte de los asuntos públicos. No hay razones para creer que el Gobierno de la Coalición por el Cambio, asumido en marzo de 2010, salvo los esperables "matices" producidos por el cambio de administradores, vaya a dejar de lado esta tan conveniente política de "consenso", sobre todo, si se considera que carece de mayoría parlamentaria.

${ }^{216}$ LAMPEDUSA, Giussepe, El Gatopardo, Ed. R. Pinto, trad., Diego Lara, Madrid: Cátedra, 2003, 285 pp., p. 66. 
Polit. crim. Vol. 5, No 9 (Julio 2010), Art. 4, pp. 143-206.

[http://www.politicacriminal.cl/Vol_05/n_09/Vol5N9A4.pdf]

BECA, Manuel, "Estados antisociales. Aspecto Psiquiátrico", Revista de Ciencias Penales, t. XI (1949), pp 62-67.

BERNALES, Emmanuel; MATUS, Jean Pierre (Prof. Guía), Álvaro Bunster Briceño: vida, obra e influencia en el Derecho penal actual, Memoria de Grado U. de Talca, Talca: 2009, 65pp.

BIBLIOTECA DEL CONGRESO NACIONAL, Reseñas Parlamentarias, disponible en Internet http://biografias.bcn.cl/pags/biografias [visitado por última vez el 15.03.2010].

BRAVO LIRA, Bernardino, "Bicentenario del Código Penal de Austria: su proyección desde el Danubio a Filipinas“, en Revista de Estudios Histórico-Jurídicos, ํㅜ 26 (2004), pp. 115-155, disponible en Internet en: http://www.scielo.cl/scielo.php?script=sci_arttext\&pid=S071654552004002600005\&lng=es\&nrm=iso, [visitado por última vez el 15.03.2010].

BRÜCHER, Eduardo, "Anotaciones médico-legales al Proyecto de Código penal SilvaLabatut", Revista de Ciencias Penales, t. IV (1938), pp. 379-392 y 465-470.

CABELLO, Carlos; MATUS, Jean Pierre (Prof. Guía), Rafael Fontecilla Riquelme, vida, obra e influencia en el Derecho penal chileno, Talca: U. de Talca (Memoria de Grado), 2005, 65 pp.

CABIESES, Ricardo, Derecho penal, Apuntes de clases tomados por R. Belmar, P. Gandulfo y J. Guerrero, ampliados y redactados, Santiago de Chile: Imp. Estrella del Pacífico, 1918, 221 pp.

CANDINA POLOMER, Azun, "Seguridad Ciudadana y Sociedad en Chile Contemporáneo. Los delincuentes, las políticas y los sentidos de una sociedad", Revista de Estudios Históricos, Vol. 2, $\mathrm{N}^{\mathrm{o}} 1$ (2005), en http://www.estudioshistoricos.uchile.cl/CDA/est hist simple/0,1474,SCID\%253 D15047\%2526ISID\%253D540\%2526PRT\%253D15044,00.html [visitado por última vez el 15.03.2010].

CARNEVALI, Raúl, "La ciencia penal italiana y su influencia en Chile", Política criminal, $\mathrm{N}^{\circ} 6$ (2008), A4-6, pp. 1-19.

CARRARA, Francesco, Programa de Derecho Criminal, t. I, $1^{o}$, (1859), trads. J. Ortega y J. Guerrero, Bogotá: Temis, 1956, 383pp.

CORREA S., Sofía; FIGUEROA G., Consuelo; JOCELYN-HOLT, Alfredo; ROLLE C., Claudio; VICUÑA U., Manuel, Historia del Siglo XX chileno. Balance paradojal, Santiago de Chile, Ed. Sudamericana, 2001, 428 pp.

COUSIÑO MAC IVER, Luis, Derecho penal chileno, $t$. I, Santiago: Ed. Jurídica de Chile, 1975, 960 pp.

CURY U., Enrique, El delito continuado, Memoria de Prueba U. de Chile, Santiago de Chile: Ed. Jurídica, 1962, 119 pp.

CURY, Enrique, Derecho penal, parte general, $7^{a}$ ed. Ampliada, Santiago: Ed. Universidad Católica de Chile, 2005, 812 pp.

DEL RÍO, Raimundo, Apuntes del Derecho penal, Santiago de Chile: 1922, 356 pp.

DEL RIO, Raimundo, Derecho penal, t. I, Santiago de Chile: Ed. Nascimento, 1935, 320 pp.,

DEL RÍO, Raimundo, El problema penal, Memoria de Prueba, Santiago de Chile: Imp. Universitaria, 1916, $104 \mathrm{pp}$.

ESPINOZA H., Mauricio; MATUS, Jean Pierre (Prof. Guía), Gustavo Labatut Glena: vida, obra y aporte al Derecho penal actual, Talca: Memoria de Grado U. Talca, 2005, 65 pp.

ESTELLÉ, Patricio, "Un proyecto de código para Chile", Historia, No 12 (1974-1975), 1976, pp. 375-381. 
MATUS, JEAN PIERRE. "La doctrina penal de la (fallida) recodificación chilena del Siglo XX y principios del XXI".

ETCHEBERRY O., Alfredo, "Reflexiones sobre Política Criminal," Política Criminal $\mathrm{N}^{\mathrm{o}} 7$ (2009), D2-7, pp. 1-16

ETCHEBERRY O., Alfredo., El concurso aparente de de leyes penales, Santiago de Chile: Ed. Jurídica de Chile, 1955, 118 pp.

ETCHEBERRY, Alfredo, "Centenario del Código penal chileno: ¿permanencia o caducidad?", en RIVACOBA, Manuel (Ed.), Actas de las Jornadas Internacionales de Derecho penal en celebración del centenario del Código penal chileno, Valparaíso: Edeval, 1975, 398 pp., pp. 373-379.

ETCHEBERRY, Alfredo, Derecho penal, parte general, t. I, $3^{a}$ ed. Revisada y actualizada, Santiago: Ed. Jurídica de Chile, 1997, 361 pp.

FERNÁNDEZ C., José Ángel, "El Nuevo Código Penal: una lucha por el discurso de la criminalidad", Política Criminal, no 1 (2006), A5, pp. 1-30.

FERNÁNDEZ, Pedro Javier, Código penal de la República de Chile, esplicado y anotado, Santiago de Chile: Imp. El Mercurio, 1877, 143 pp.

FERNÁNDEZ, Pedro Javier, Código penal de la República de Chile, esplicado y concordado, $2^{a}$ edición notablemente aumentada i corregida, $t$. I, Santiago de Chile: Imp. Barcelona, 1899, 452 pp.

FIGUEROA, María Angélica, "La codificación civil chilena y la estructuración de un sistema jurídico legalista", en FACULTAD DE DERECHO DE LA UNIVERSIDAD DE CHILE, Congreso Internacional: Andrés Bello y el Derecho, realizado con motivo del bicentenario de su nacimiento, Santiago de Chile: Ed. Jurídica de Chile, 1982, pp. 77-104.

FILIPENSKY, Francisco, "Los Estados anti-sociales. Aspecto policial", Revista de Ciencias Penales, t. XI (1949), pp. 68-73.

FONTECILLA, Rafael, Estudio sobre las expropiaciones por causa de utilidad pública, Santiago: Imp. Bellavista, 1914, 46 p.

FONTECILLA, Rafael, La Pena (evolución natural, jurídica y técnica). Los Problemas Modernos y sus influencias en el Nuevo Derecho Penal Chileno, Santiago, Imp. Cisneros: 1930, 424 pp.

FUENZALIDA, Alejandro, Concordancias y Comentarios del Código Penal Chileno, $t$. I, Lima: Imp. Comercial, 1883, 402 pp.

GARRIDO M., Mario, Los delitos contra el honor, Santiago de Chile: Carlos Gibbs Ed., 1963, $381 \mathrm{pp}$.

GREZ TOSO, Sergio, La "cuestión social" en Chile. Ideas y debates precursores : (1804-1902), Biblioteca Nacional de Chile, disponible en Internet en http://www.cervantesvirtual.com/servlet/SirveObras/12475174324514951887891/ p0000001.htm [última visita: 15.03.2010].

GRISOLÍA, Francisco, "La reforma penal en Chile", Anuario de Derecho Penal y Ciencias Penales, Madrid (1967), pp. 289-332.

GRISOLÍA, Francisco, El Código penal tipo para Hispanoamérica. Proceso formativo y estudio crítico, Tesis Doctoral, Madrid: U. Complutense, 1967, $151 \mathrm{pp}$.

GUERRA G., Beatriz; MATUS, Jean Pierre (Prof. Guía), Eduardo Novoa Monreal: vida, obra e influencia dogmática en el Derecho penal actual, Memoria de Prueba U. Talca: Talca, 2005, 84 pp.

GUZMÁN BRITO, Alejandro, "Para la historia de la fijación del Derecho civil en Chile durante la República (XII). Diego Portales y la codificación", Revista Chilena de Historia del Derecho, vol. 16 (1990), pp. 263-274.

GUZMÁN BRITO, Alejandro, Historia de la codificación civil en Iberoamérica, Navarra: Thomson / Aranzadi, 2006, 586 pp. 
Polit. crim. Vol. 5, No 9 (Julio 2010), Art. 4, pp. 143-206.

[http://www.politicacriminal.cl/Vol_05/n_09/Vol5N9A4.pdf]

GUZMÁN BRITO, Alejandro, Historia de la codificación civil en Iberoamérica, Navarra: Thomson / Aranzadi, 2006, 586 pp.

GUZMÁN BRITO, Alejandro, La fijación del derecho, Valparaíso: Ed. Universidad de Valparaíso, 1977, 128 pp.

HERNÁNDEZ B., Héctor, "Aproximación a la problemática de la estafa", en: VV. AA., Problemas actuales de Derecho Penal, Temuco: Universidad Católica de Temuco, 2003, pp. 148-190.

HORVITZ L., María Inés; SOTO P., Miguel, "Consideraciones críticas sobre la regulación del delito de aborto en el anteproyecto de nuevo código penal elaborado por el foro del Ministerio de Justicia", Revista de Estudios de la Justicia, no 9 (2007), pp. 75-120.

HORVITZ, Ma Inés; LÓPEZ, Julián, Derecho procesal penal chileno, $t$. I, Santiago: ed. Jurídica de Chile, 2002, 638 pp.

INSTITUTO DE CIENCIAS PENALES, Evocación de procesos penales olvidados, discurso de incorporación del Académico D. Pedro Silva Fernández y Discurso de recepción de D. Arturo Alessandri Rodríguez, Santiago: Ed. Andrés Bello, 1966, 20 pp.

INSTITUTO DE CIENCIAS PENALES, Proyecto de Código penal tipo para Iberoamérica. Antecedentes, plan de trabajo, documentos preparatorios, Santiago de Chile: 1963, 21 pp.

JAKSIC, Iván, Andrés Bello: la pasión por el orden, Santiago de Chile: Ed. Universitaria, 2001, $311 \mathrm{pp}$.

JIMÉNEZ DE ASÚA, Luis, Tratado de Derecho penal, t. I. Concepto del Derecho penal y de la Criminología, Historia y legislación penal comparada, $5^{a}$ ed., Buenos Aires: Ed. Losada, 1963 (imp. de 1992), 1435 pp.

JOCELYN-HOLT, Alfredo, "El liberalismo moderado del Siglo XIX", Revista de Estudios Públicos, № 69 (1998), pp. 439-485

JOCELYN-HOLT, Alfredo, "El liberalismo moderado del Siglo XIX", Revista de Estudios Públicos, № 69 (1998), pp. 439-485.

KÜNSEMÜLLER, Carlos.,"Los principios cardinales del ius puniendi a la luz de algunos delitos contra la propiedad contemplados en el Anteproyecto de Código Penal redactado por el Foro Penal," Politica Criminal, nº1 (2006), A3, p. 1-14.

LABATUT, Gustavo, "La peligrosidad de las personas naturales en el Proyecto de Código Penal Chileno," Revista de Ciencias Penales. t. IV (1938), pp. 289-296.

LABATUT, Gustavo, Manual de Derecho penal, t. I. $3^{a}$ ed., Santiago: Ed. Jurídica de Chile, 1958, $480 \mathrm{pp}$.

LABATUT, Gustavo, Manual de Derecho penal. Santiago: s/e, 1948, 551 pp.

LABATUT, Gustavo; SILVA, Pedro, "Nota", Revista de Ciencias Penales, t. IV (1938), pp. 79-192.

LAMPEDUSA, Giussepe, El Gatopardo, Ed. R. Pinto, trad., Diego Lara, Madrid: Cátedra, 2003, 285 pp.

LAZO, Santiago, Código penal, orígenes, concordancias, jurisprudencia, Santiago de Chile: Ed. Poblete Cruzat Hnos., 1915, 500 pp.

LAZO, Santiago, Código penal, orígenes, concordancias, jurisprudencia, Santiago de Chile: Ed. Poblete Cruzat Hnos., 1915, 500 pp.

LEÓN, Marco Antonio, "Las ideas sobre la ley y el pueblo en la construcción y consolidación de la República chilena (1810-1860)", Historia Crítica (Bogotá), 2008, pp. 82-101 
MATUS, JEAN PIERRE. "La doctrina penal de la (fallida) recodificación chilena del Siglo XX y principios del XXI".

MATUS, Jean Pierre (Ed.), Derecho Penal del Medio Ambiente. Estudios y propuesta para un nuevo Derecho penal ambiental chileno, Santiago: ed. Jurídica de Chile, 2004, 246 pp.

MATUS, Jean Pierre, "El positivismo en el Derecho penal chileno: análisis sincrónico y diacrónico de una doctrina de principios del Siglo XX que se mantiene vigente, Rev. Derecho (Valdivia), vol. 20, $\mathrm{n}^{\circ} 1$ (2007), pp. 175-203.

MATUS, Jean Pierre, "Fernández, Fuenzalida y Vera: Comentaristas, autodidactas y olvidados. Análisis diacrónico y sincrónico de la doctrina penal chilena del siglo XIX”, Ius et Praxis, Vol. 12, no 1 (2006), pp. 31-67.

MATUS, Jean Pierre, "Por qué citamos a los alemanes y otros apuntes metodológicos," Politica Criminal, $\mathrm{n}^{\mathrm{o}} 5$ (2008), A5-5, pp. 5-7, en: http://www.politicacriminal.cl/n 05/a 5 5.pdf [visitado por última vez el 15.03.2010].

MATUS, Jean Pierre, "Sergio Yáñez, obra e influencia: la dogmática chilena actual”, en Revista de derecho (Coquimbo), pp. 113-130.

MATUS, Jean Pierre, La transformación de la teoría del delito en el Derecho penal Internacional, Barcelona: Atelier, 2008, 185 pp.

MATUS, Jean Pierre; HERNÁNDEZ, Héctor (SECRETARÍA TÉCNICA COMISIÓN FORO PENAL), "Anteproyecto de Código Penal de 2005, preparado por la Comisión Foro Penal," Política Criminal, n 1 (2006), D1, disponible en Internet en http://www.politicacriminal.cl [visitada por última vez el 20.03.2010].

MATUS, Jean Pierre; HERNÁNDEZ, Héctor (SECRETARÍA TÉCNICA COMISIÓN FORO PENAL), "Materiales de Estudios presentados a la Comisión Foro Penal, Parte General," Política Criminal, $\mathrm{n}^{\mathrm{o}} 1$ (2006), D2, disponible en Internet en http://www.politicacriminal.cl [visitada por última vez el 20.03.2010].

MATUS, Jean Pierre; HERNÁNDEZ, Héctor (SECRETARÍA TÉCNICA COMISIÓN FORO PENAL), "Materiales de Estudios presentados a la Comisión Foro Penal, Parte Especial," Política Criminal, n 1 (2006), D3, disponible en Internet en http://www.politicacriminal.cl [visitada por última vez el 20.03.2010].

MERA F., Jorge, El delito de entrega fraudulenta. Santiago de Chile: Ed. Encina, 1971, $269 \mathrm{pp}$.

MEZGER, Edmund, Tratado de Derecho penal, t. II, $2^{a}$ ed. (1933), trad. J. RODRÍGUEZ MUÑOZ, Madrid: Ed. Rev. de Derecho Privado, 1949, 453 pp.

MINISTERIO DE JUSTICIA, Proyecto de Código penal, Santiago: Imp. Nacional, 1929, $123 \mathrm{pp}$.

MONTERO SCHMIDT, Mario. "El pensamiento jurídico penal de Pedro Ortiz", Revista de Ciencias Penales, t. X, no 2 (1948), p. 110 y siguiente.

MULIÁN, Tomás, Fracturas. De Pedro Aguirre Cerda a Salvador Allende (19381973), Santiago de Chile: LOM, 2006, 274 pp.

NEIRA, Marcelo, "Jeremy Bentham y el liberalismo en Chile durante la primera mitad del siglo XIX”, Boletín de la Academia Chilena de la Historia, № 113 (2004), pp. 285-313.

NOVOA MONREAL, Eduardo, Curso de Derecho penal chileno, Parte general, t. I, $3^{\circ}$ ed. Texto original (1960) con notas, Santiago: 2005, $585 \mathrm{pp}$.

NOVOA MONREAL, Eduardo, Curso de Derecho penal chileno, Parte general, $t$. II, $3^{\circ}$ ed. Texto original (1960) con notas, Santiago: 2005, 475 pp.

ORTIZ MUÑOZ, Pedro, "Los Problemas de la Reforma Penal", Revista de Ciencias Penales, t. I (1935), p. 13-15.

ORTIZ MUÑOZ, Pedro, La ilegitimidad y la ley de matrimonio civil; reformas necesarias, Santiago de Chile: Imp. Selecta, 26 pp. 
Polit. crim. Vol. 5, No 9 (Julio 2010), Art. 4, pp. 143-206.

[http://www.politicacriminal.cl/Vol_05/n_09/Vol5N9A4.pdf]

ORTIZ MUÑOZ, Pedro, Nociones Generales de Derecho Penal, t. I, Santiago: Nascimento, 1933, 226 pp.

ORTIZ Q., Luis, Teoría de las hipótesis preterintencionales, Santiago de Chile: Ed. Jurídica, 1959, 107 pp.

OSSANDÓN, M ${ }^{\mathrm{a}}$ Magdalena. "Delitos especiales y de infracción de deber en el Anteproyecto de Código Penal", Política Criminal, n 1 (2006), A4, p. 1-22.

PACHECO, Joaquín Francisco, El Código penal concordado y comentado, t. I, Madrid: Imp. Saunaque, 1848, $551 \mathrm{pp}$.

PEÑA, Federico, "Observaciones al nuevo Proyecto de Código penal", Revista de Ciencias Penales, t. IV (1938), pp. 379-392 y 465-470.

POLITOFF, Sergio, El delito de apropiación indebida, Santiago de Chile: Ed. Nascimento, 1957, $241 \mathrm{pp}$.

POLITOFF, Sergio; MATUS, Jean Pierre; RAMÍREZ, M ${ }^{\mathrm{a}}$ Cecilia, Lecciones de Derecho penal chileno, parte general, $2^{a}$ ed., Santiago: Ed. Jurídica de Chile, 613 pp.,

POLITOFF, Sergio; BUSTOS R., Juan; GRISOLÍA, Francisco, Derecho penal chileno, parte especial, Santiago de Chile: Ed. Jurídica de Chile, 1971, 396 pp.

PORTALES, Felipe, "Los mitos de la democracia chilena en torno al bicentenario", en Omnibus, Año 7, II (2006), en http://www.omnibus.com/n7/chiledemocracia.html [visitado por última vez el 15.03.2010].

Proyecto de Reforma del Código penal, Libro Primero, elaborado por la Comisión designada en el Decreto Supremo Núm. 2.729 de 15 de junio de 1945, del Ministerio de Justicia, Santiago de Chile: Dirección General de Prisiones, 1946, $158 \mathrm{pp}$.

Proyecto de Reforma del Código penal, Libro Primero, Santiago de Chile: Dirección General de Prisiones, 1946, 158 pp.

RAMÍREZ, María Cecilia, "Anteproyecto de Código Penal: hacia una racionalización de las circunstancias modificatorias de responsabilidad penal. El caso de las agravantes", Política Criminal, nº (2007), A2, pp. 1-22.

RAMÓN, Armando de (Ed.), Biografías de chilenos, vol. I, Santiago: Ed. Universidad Católica de Chile, 1999, 335 pp.

RAMÓN, Armando de (Ed.), Biografías de chilenos, vol. II, Santiago: Ed. Universidad Católica de Chile, 1999, 269 pp.

RAMÓN, Armando de (Ed.), Biografías de chilenos, vol. IV, Santiago: Ed. Universidad Católica de Chile, 2003, 321pp.

RIVACOBA, Manuel de, "El Primer Proyecto Americano de Código penal", Anales del Instituto de Chile (1985), pp. 85-93.

RIVACOBA, Manuel de, Evolución histórica del Derecho penal chileno, Valparaíso: Edeval, 153 pp.

RIVACOBA, Manuel, "Estudio Preliminar", en Código penal de la República de Chile y Actas de las sesiones de la Comisión redactora del Código penal chileno, Valparaíso: Edeval, 1974, 574 pp.

RIVACOBA, Manuel, "Pensamiento penal y criminológico del Código penal tipo para Iberoamérica", Doctrina penal, Año 10, nº 37 a 40 (1987), pp.713-734.

RODRÍGUEZ-COLLAO, Luis, "Sobre la regulación de los delitos contra la integridad sexual en el Anteproyecto de Código Penal", Política Criminal, nº 1 (2006), A1, pp. 1-19.

RÜPING, Hinrich, Grundriß der Strafrechtsgeschichte, 3. Auf., München: C.H. Beck, 1998, 137 pp. 
MATUS, JEAN PIERRE. "La doctrina penal de la (fallida) recodificación chilena del Siglo XX y principios del XXI".

SCHEPELER, Enrique, "Estados anti-sociales. Aspecto Jurídico", Revista de Ciencias Penales, t. XI (1949), pp. 53-61.

SILVA FERNÁNDEZ, Pedro, "La responsabilidad penal de las personas jurídicas", Revista de Ciencias Penales, t. IV (1938), pp. 317-329.

URIBE A., Armando., De los delitos calificados por el resultado, Santiago de Chile: Ed. Jurídica, 1957, 75 pp.

VERA, Robustiano, Código penal de la República de Chile comentado, Santiago: Imp. Cadot, 1883, 840pp.

VERA, Robustiano, Teorías del Derecho penal, $2^{a}$ ed., Santiago de Chile: Imp. De la República, 1882, 174 pp.

VILLEGAS, Myrna, "Los delitos de terrorismo en el Anteproyecto de Código Penal", Politica Criminal, $\mathrm{n}^{\mathrm{o}} 2$ (2006), A3, pp. 1-31.

VIVANCO S., Jaime, El delito de robo con homicidio. Ensayo a la luz de la doctrina del delito-tipo, Santiago de Chile: Ed. Jurídica, 1957, 102 pp. 